NBER WORKING PAPER SERIES

\title{
EAT WIDELY, VOTE WISELY? LESSONS FROM A CAMPAIGN AGAINST VOTE BUYING IN UGANDA
}

\author{
Christopher Blattman \\ Horacio Larreguy \\ Benjamin Marx \\ Otis R. Reid \\ Working Paper 26293 \\ http://www.nber.org/papers/w26293 \\ NATIONAL BUREAU OF ECONOMICS RESEARCH \\ 1050 Massachusetts Avenue \\ Cambridge, MA 01238 \\ September 2019
}

For implementation we thank the Alliance for Election Campaign Finance Monitoring (ACFIM) and the National Democratic Institute (NDI) in Uganda; we are particularly indebted to Teresa Lezcano Cadwallader, Henry Muguzi, Simon Osborn, and Ivan Tibemanya. We are grateful to Kelsey Barrera, Alex Nawar, and Harrison Pollock for their outstanding research management and assistance in Uganda, to the entire executive staff at IPA Uganda for ensuring the completion of the survey work, and we thank Peter Deffebach and Patryk Perkowski for excellent research assistance in the United States. We also thank Pia Raffler and Melina Platas Izama for sharing data and providing advice on field operations. We benefited from helpful comments and suggestions from Daron Acemoglu, Aislinn Bohren, Erika Deserranno, Michael Kremer, Marco Gonzalez-Navarro, Edmund Malesky, Ben Olken, Berk Ozler, Nancy Qian, Jorg Spenkuch, David Stromberg, Rebecca Weitz-Shapiro, and the EGAP peer response system (in particular, Katherine Casey, Nahomi Ichino and Macartan Humphreys), and participants at APSA 2016, CAF Development Bank of Latin America, Harvard University, the Institute for International Economic Studies (IIES) at Stockholm University, MIT, Northwestern University, Ryerson University, UCL, the University of Houston, the University of Toronto, Uppsala University, Warwick University, and WPSA 2017. We gratefully acknowledge financial support from the JPAL Governance Initiative and the International Growth Centre. The views expressed herein are those of the authors and do not necessarily reflect the views of the National Bureau of Economic Research.

At least one co-author has disclosed a financial relationship of potential relevance for this research. Further information is available online at http://www.nber.org/papers/w26293.ack

NBER working papers are circulated for discussion and comment purposes. They have not been peer-reviewed or been subject to the review by the NBER Board of Directors that accompanies official NBER publications.

(C) 2019 by Christopher Blattman, Horacio Larreguy, Benjamin Marx, and Otis R. Reid. All rights reserved. Short sections of text, not to exceed two paragraphs, may be quoted without explicit permission provided that full credit, including (C) notice, is given to the source. 
Eat Widely, Vote Wisely? Lessons from a Campaign Against Vote Buying in Uganda Christopher Blattman, Horacio Larreguy, Benjamin Marx, and Otis R. Reid NBER Working Paper No. 26293

September 2019

JEL No. C93,D72,O55

\begin{abstract}
$\underline{\text { ABSTRACT }}$
We estimate the effects of one of the largest anti-vote-buying campaigns ever studied — with half a million voters exposed across 1427 villages-in Uganda's 2016 elections. Working with civil society organizations, we designed the study to estimate how voters and candidates responded to their campaign in treatment and spillover villages, and how impacts varied with campaign intensity. Despite its heavy footprint, the campaign did not reduce politician offers of gifts in exchange for votes. However, it had sizable effects on people's votes. Votes swung from wellfunded incumbents (who buy most votes) towards their poorly-financed challengers. We argue the swing arose from changes in village social norms plus the tactical response of candidates. While the campaign struggled to instill norms of refusing gifts, it leveled the electoral playing field by convincing some voters to abandon norms of reciprocity-thus accepting gifts from politicians but voting for their preferred candidate.

Christopher Blattman

Harris School of Public Policy

The University of Chicago

1307 E 60th St

Chicago, IL 60637

and NBER

blattman@uchicago.edu

Horacio Larreguy

Harvard University

Department of Government

1737 Cambridge Street

CGIS Knafel Building 408

Cambridge, MA 02138

hlarreguy@fas.harvard.edu

Benjamin Marx

Sciences Po

Department of Economics

28 Rue des Saints-Peres

75007 Paris

France

benjamin.marx@ sciencespo.fr

Otis R. Reid

Massachusetts Institute of Technology

otis.russell.reid@gmail.com
\end{abstract}

A randomized controlled trials registry entry is available at https://www.socialscienceregistry.org/trials/965 


\section{Introduction}

Democracy in many developing countries is undermined by widespread vote buying — the provision of cash or goods in exchange for votes (Vicente and Wantchekon, 2009; Hicken, 2011; Cruz et al., 2017). Candidates and their intermediaries, commonly known as brokers, use many tactics to buy votes, from giving likely supporters an incentive to turn out, to targeting the individuals most likely to reciprocate the gift with a vote (Nichter, 2008; Finan and Schechter, 2012). Such endemic vote-buying practices impede economic development by fostering corruption and by limiting political accountability and the provision of public goods (Stokes, 2005; Robinson and Verdier, 2013; Khemani, 2015).

Policy experiments designed to eradicate vote buying have found that small-scale interventions convince some voters to refuse to sell their vote, which hurts the electoral performance of vote-buying candidates (Vicente, 2014; Hicken et al., 2017; Vasudevan, 2018). Others have shown that reducing economic vulnerability undermines clientelistic exchanges with incumbent politicians, who may lose electoral support as a result (Bobonis et al., 2017; Larreguy et al., 2018; Frey, 2019). One of the most important and least settled questions, however, is whether these interventions reduce overall vote buying or merely displace it. In addition, it is unclear if these changes are likely to be durable, whether through changes in social norms or the electoral tactics of politicians.

Campaigns against vote buying can affect the behavior of both voters and candidates in a number of ways. On the voter (or supply) side, citizens may start refusing offers of gifts in exchange for their vote. Or they might react by accepting gifts from one or even several politicians, but voting for their preferred candidate anyway - a behavior that we call a violation of reciprocity. Understanding how norms and behavior evolve among voters can inform the design of anti-vote-buying policies. On the candidate (or demand) side, politicians and their agents may reallocate their efforts towards voters not exposed to such policies. The net effect of anti-vote buying programs on offers made by different candidates is ambiguous and depends on the extent to which vote-buying offers become ineffective. Because the responses to interventions against vote buying are complex and potentially differ across buyers and sellers of votes, it is important to track effects among voters as well as candidates, and in both treated and untreated areas. This requires a tailored design, detailed data on vote buying arrangements, and a much larger sample size than normal for randomized trials.

This paper explores these questions by studying an unusually large civil society intervention in Uganda, a low-income East African country where one political party and its leader have held power since 1986. Many experts consider Uganda a "multiparty autocracy" or a "hegemonic party system" at the Presidential level (Tripp, 2010). At other levels, however, polls are fairly competitive. As in many other developing countries, vote buying has long been endemic in Uganda, and most votes are bought by incumbents (Conroy-Krutz, 2012). The extensive fieldwork we conducted prior to the intervention confirmed the ubiquity of vote buying, while shedding light on the role that prevailing social norms and political machines play in sustaining it.

Ahead of Uganda's 2016 general elections, we partnered with the largest collective of electoral civil society organizations in Uganda, the Alliance for Election Campaign Finance Monitoring (ACFIM), and its international partner the National Democratic Institute (NDI). We studied their village-level cam- 
paign, which they designed to undermine norms of accepting and reciprocating gifts with votes, as well as to foster new community strategies against vote selling. Their campaign and its evaluation were unprecedented in scale. The villages in the experimental sample (including control) cover around 1.2 million people registered to vote in the 2016 Ugandan general election, $6 \%$ of the country's polling stations, and $12 \%$ of polling stations in the 53 districts we study.

We designed the randomization strategy to measure spatial spillovers of ACFIM's campaign, in particular the effects driven by changes in candidate behavior within treated parishes. Our pre-intervention fieldwork showed that the "parish" - a collection of 3 to 10 villages—is the typical operating unit for the rural vote brokers who work for politicians. Before their 2016 campaign, ACFIM activists were based in 2,796 villages across 918 parishes in 53 districts. We call these "eligible villages" because of their potential to receive the campaign. We randomized roughly two thirds of the 918 parishes to treat at least one eligible village in the parish; one third had no villages treated. ${ }^{1}$ Within treated parishes we then varied treatment saturation by randomizing the fraction of eligible villages targeted by the campaign. This approach yielded 1,427 treated villages. Within a treated parish, saturation varied from 3 to 100\% of all villages.

Hence, our design gives us directly treated villages, "spillover" villages (untreated villages in treated parishes), and pure control villages (in control parishes). Due to the geographic dispersion of parishes, electoral behavior across parishes is generally independent. This allows us to estimate average treatment and spillover effects of the ACFIM campaign, and how these effects vary with treatment saturation at the parish level. This approach builds on a new strand of empirical work designed to uncover spillover and general equilibrium effects in experimental settings. ${ }^{2}$

ACFIM's campaign began a month prior to the 2016 election and included five main elements: (i) a leaflet drop; (ii) three village meetings organized by local ACFIM activists to build awareness of, and opposition to vote buying; (iii) a public village-wide resolution against vote buying; (iv) posters reminding voters about this resolution; and (v) an automated-call reminder on the eve of the election. These five activities were designed to generate two kinds of norm and behavior changes. One was to encourage people to refuse gifts offered by politicians, i.e., to introduce a refusal norm. The other was to encourage those who received a gift to still vote their personal preference. In this way, the campaign sought to weaken the reciprocity norm associated with vote buying. Since vote choice is unobserved, reciprocity is essential to vote-buying arrangements (Finan and Schechter, 2012).

ACFIM chose its activities to affect these norms and behaviors in three ways. The first was to use information and persuasion to change generalized beliefs and individually-held values (internalized norms) around refusal and reciprocity. The leaflets and first informational meetings were designed with this goal in mind; both emphasized the costs of vote selling in terms of corruption and public service delivery. Second, ACFIM facilitated community discussions, coordinated public commitments, displayed posters, and made robocalls to give villagers a shared sense of new standards of behavior in the community-in favor of refusal and against reciprocity. That is, ACFIM tried to change real and perceived norms of behavior. In principle, villagers could change their behavior because of psychic

\footnotetext{
${ }^{1}$ Section 3.3 provides a detailed description of our randomization strategy.

${ }^{2}$ Baird et al. (2018) provide a review of this literature.
} 
penalties (such as shame, or the fear of social sanctions) caused by deviating from generally accepted standards of conduct. Third, the public commitments, posters, and robocalls were also a signal to politicians that village norms had changed, and that their vote-buying transactions might not be welcomed or honored in that village.

Shortly after the elections, we surveyed 28,454 villagers, collecting a wealth of data on people's experience with vote buying. We surveyed all 2,796 eligible villages in the 918 parishes in our experimental sample. To increase our power to estimate spatial spillovers, we also surveyed 1,399 nearby ("ineli-

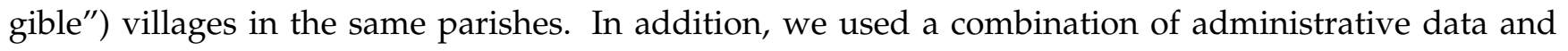
qualitative accounts from voters and brokers affected by the intervention to measure the impacts of the ACFIM campaign and to better understand how the two sides of the vote-buying market responded to the ACFIM campaign.

Our key finding is that the campaign had substantial effects on electoral outcomes, even though it did not reduce the extent of vote buying. In areas exposed to the campaign, vote shares decreased for incumbents and correspondingly rose for challenger (non-incumbent) candidates running in the presidential and parliamentary races. ${ }^{3}$ The vote share accruing to incumbents decreased by 0.06 standard deviations (sd) in both treatment and spillover villages, amounting to $0.185 \mathrm{sd}$ in fully treated parishes. However, contrary to our partners' expectations, as well as our preregistered hypotheses, we see little evidence that the campaign reduced politicians' offers of vote buying, or the extent to which voters refused them. On the contrary, there was a sizable (but insignificant) increase in a standardized index of vote buying in treated parishes. This increase was driven by challenger candidates, as we document below.

We try to unpack mechanisms by exploring the behavior of agents on both sides of the market for votes, both through surveys and a large and systematic set of qualitative interviews with voters and brokers. First, we observe changes in social norms among citizens. The ACFIM campaign slightly reduced the perception that others in their village would sell their vote by about $0.06 \mathrm{sd}$. Similarly, respondents in treated villages were more aware of the negative consequences vote buying could have for their village, and more likely to expect social sanctions for selling their vote. Of course, these changes in perceived norms of refusal did not translate into changes in actual refusal behavior, since overall the campaign did not reduce the extent to which voters accepted gifts from candidates.

Next, we turn to the responses of candidates and their brokers. Incumbent candidates, who engaged in the bulk of vote buying prior to the intervention, did not reduce their vote-buying efforts in treated villages. However, challenger candidates increased their attempts to buy votes in both treated and spillover villages, by about $0.06 \mathrm{sd}$. We also see an increase in campaigning efforts by challengers in high-saturation parishes. ${ }^{4}$ The brokers we interviewed reported that unlike incumbents, challenger candidates intensified their standard campaigning tactics around the ACFIM campaign. Our quantitative results and interviews with brokers indicate these effects are partly explained by the brokers acting on behalf of challengers entering vote-buying markets where they were previously deterred from operating.

\footnotetext{
${ }^{3}$ In the parliamentary election, $69 \%$ of incumbents were affiliated with the ruling party at the national level. We preregistered the distinction between incumbents and challengers (rather than a distinction between ruling party and opposition candidates) because incumbents are well-funded and buy most votes, as well as to maintain strict confidentiality of the results.

${ }^{4}$ We preregistered that the ACFIM campaign would affect candidates' campaigning tactics, with the sign of this effect depending on whether those tactics are complements or substitutes to vote buying.
} 
Overall, neither the shift in perceived refusal norms nor the change in challenger vote buying alone seems large enough to explain the sizable swing in vote shares. After the campaign, challengers still bought many fewer votes than incumbents, in absolute terms. Our preferred interpretation, therefore, is that changes in social norms and candidate behavior led to an erosion of reciprocity behavior on the voter side. Facing multiple vote-buying offers, voters still accepted gifts from candidates but were less willing to reciprocate them with their votes, and voted for their preferred candidate instead. A slogan often heard in our qualitative work, "eat widely, but vote wisely," summarizes the new approach taken in villages exposed to the campaign. Villagers told us how the campaign inspired them to take cash and gifts from all candidates, and then vote for whom they liked. We find some evidence of voter behavior consistent with this interpretation. The campaign increased the likelihood that voters accepted gifts from both incumbents and challengers running in the same race, and that voters accepted gifts from a candidate but voted for another. These findings suggest that campaigns against vote buying can be effective if they tackle reciprocity norms instead of refusal norms.

Our interviews with 438 brokers, conducted after the election, provide more evidence that the campaign weakened the effectiveness of vote buying by well-funded incumbents, and prompted a change in challengers' tactics. Brokers working for incumbents told us that they did not expect the ACFIM campaign to have much of an effect, since voters continued to accept the cash and gifts. In contrast, challengers and their brokers told us that they hoped the ACFIM campaign would level the electoral playing field by weakening reciprocity norms, which previously benefited incumbents. As a result, challengers' responded to ACFIM's campaign by buying more votes and campaigning in markets where rich incumbents had deterred challengers before. This gave voters multiple offers to choose from, sometimes for the first time, and may have contributed to the breakdown of reciprocity. While these qualitative accounts are retrospective and self-reported by voters and brokers, they provide interesting insights into the response of political machines to an anti-vote-buying campaign that was unprecedented in its scale.

Related Literature. Our findings provide a better understanding of the possible effects of large-scale policies designed to promote better governance and political accountability in developing countries. Previous work has shown that changes in social norms induced by large policy experiments can affect electoral behavior and political attitudes (Beaman et al., 2009; Berman et al., 2014; Gerber and Green, 2017). We show that informing voters about a general feature of the political system-vote buying and its social costs — can shift actual and perceived norms of behavior, influence the campaigning strategies of political candidates, and change voting outcomes.

A smaller literature specifically explores the effectiveness of programs designed to combat vote buying. In seminal work, Vicente (2014) finds that a voter education campaign in São Tomé and Príncipe reduced the reported influence of money received on candidate choice, decreased voter turnout, and favored the incumbent. Hicken et al. (2017) tackle vote selling as a time-inconsistency problem and show that ex-ante promises can reduce vote selling in the Philippines. Recent work by Vasudevan (2018) in India shows that a radio campaign led to a reduction in the vote share of candidates known to buy votes. Our experiment differed from these earlier contributions in the following ways. First, we explicitly treat vote buying as a market equilibrium problem. As a result, we not only estimate supply-side 
responses (i.e., to what extent information campaigns affect the willingness of voters to sell their vote) but we also examine the demand side-how candidates modify their campaigning tactics in the new environment created by the ACFIM campaign. Second, we evaluate a campaign that was sufficiently large and visible to trigger supply-side and demand-side responses of this kind. ${ }^{5}$ ACFIM villages in our sample covered around 1.2 million registered to vote, or $12 \%$ of the population in half of the country's districts. ${ }^{6}$ The surprising findings that this evaluation delivered further justify using experiments "at scale" whenever possible (Muralidharan and Niehaus, 2017). Third, the detailed data we collected on attitudes, campaigning tactics, and voting behavior in both treatment and spillover areas allows us to unpack the theory of change linking the ACFIM campaign with electoral behavior, including changes in social norms and in the campaigning tactics of candidates.

We also build on recent experimental work that studies whether policy campaigning can successfully substitute for vote buying, and in doing so, foster a transition from clientelistic to programmatic politics. Fujiwara and Wantchekon (2013) compare clientelistic rallies to town hall meetings addressing specific policy platforms in Benin, and find that the meetings reduced reported vote buying and lowered the candidate's vote share in his stronghold. Similarly, Bowles and Larreguy (2018) show that candidate participation in a debate initiative led to a reduction in on-the-ground campaigning. In contrast, Bidwell et al. (2019) find that debate showing increases campaign expenditures by candidates. In line with Bidwell et al. (2019), our results indicate that buying votes and campaigning on policy issues might act as complements rather than substitutes.

\section{Background}

\subsection{The 2016 Ugandan general election}

The campaign against vote buying that we evaluate was implemented in Uganda, a low-income country of about 40 million people in East Africa. Since 2006, two major political parties and a number of smaller ones have competed in national elections every five years. Despite this, the National Resistance Movement (NRM) and its leader, President Yoweri Museveni, have been in power since 1986. ${ }^{7}$ Although politics are fairly competitive at the Parliamentary level, Uganda is often regarded as a "multiparty autocracy" with endemic voter intimidation and vote buying in national elections (Tripp, 2010). ${ }^{8}$

We study vote buying and electoral behavior during the 2016 general elections, which were held on February 18. The president was elected in a two-round system, requiring at least $50 \%$ of the popular vote to be elected in the first round. Members of Parliament (MPs) were elected in single-member constituencies using first-past-the-post voting. Of the eight candidates who ran for the presidency, two

\footnotetext{
${ }^{5}$ In contrast, Vasudevan (2018)'s mass mode of delivery limits the ability of candidates to respond by strategically reallocating resources across space.

${ }^{6}$ By comparison, Vicente (2014) treats 40 enumeration areas (out of 50 that composed the experimental sample). Hicken et al. (2017) treat 600 voters (out of 900 that composed the experimental sample) privately.

${ }^{7}$ Museveni took power through military victory in 1986, under "no party rule." Elections began in 1996, but party competition was restricted. Multiparty competition was first permitted in 2006, and 2016 represents the third multiparty election.

${ }^{8}$ The Ugandan political regime was classified by the Freedom House as "not free" in 2016 (with a score of $36 \%$ ), and as a "closed anocracy" in 2015 by the Polity IV project (with a score of -1).
} 
were frontrunners from the outset: the incumbent president, Museveni, and a long-time opposition leader who was running for the fourth time, Kizza Besigye. Museveni's and Besigye's parties, the National Resistance Movement (NRM) and the Forum for Democratic Change (FDC), were also dominant in the campaigns for parliamentary seats. These parliamentary races also involve a large number of independent candidates as well as candidates from several smaller parties. ${ }^{9}$ For the parliamentary election, a total of 1,743 candidates ran for the country's 290 constituency Representative seats and 112 district Women Representative seats. Election officials set up 28,010 polling stations, $6 \%(1,603)$ of which were part of our experimental sample.

Several major incidents occurred during the 2016 electoral period. First, the leader of the opposition was arrested twice in the months leading up to the election, and subsequently was kept under house arrest. Second, security checkpoints were set up on major roads, and the presence of security forces massively increased throughout the country as the election unfolded (Amnesty International, 2016). Third, the government enforced a four-day social media blackout (Associated Press, 2016). Lastly, voting materials were delivered late to a large number of polling stations where voters were expected to vote against the NRM. The alleged goal was to generate long lines in those polling stations in order to ultimately discourage voters (Associated Press, 2016).

On February 20, 2016, Museveni was declared the winner of the presidential election with $60.8 \%$ of the vote (against 35.4\% for Besigye). Museveni's party, the NRM, also won 200 out of 290 constituency MP seats (69\%). Ugandan and international observation missions provided mixed opinions about the fairness and transparency of the election. ${ }^{10}$ For example, the EU Observation Mission cited the lack of independence of the Electoral Commission, the excessive use of force against the opposition, the "intimidating atmosphere for both voters and candidates," and "the orchestrated use of state resources and personnel for campaign purposes" as major obstacles impeding a free and fair election (European Union Election Observation Mission, 2016).

\subsection{Vote buying in Uganda}

Like other countries in Sub-Saharan Africa, Uganda has among the highest rates of vote buying in the world. Of 18 countries with Afrobarometer survey data, in 2006 Uganda had the second highest reported rate of vote buying (after Kenya), with $85 \%$ of respondents reporting that politicians "often" or "always" give gifts during political campaigns. ${ }^{11}$ Vote buying is "ubiquitous" (Democracy Monitoring Group, 2011), and previous studies have described sizable payment amounts—one such study reported that the median vote price in 2011 was 5 times the daily average income (Conroy-Krutz, 2012). As Appendix Table A1 indicates, $40 \%$ of respondents in our sample acknowledge receiving cash for their vote, with the bulk of this cash (83\%) coming from incumbent candidates.

Despite the magnitude of vote buying in Uganda, little is known about how it works in practice. To fill this gap and to explore possible intervention designs, we worked with NDI and ACFIM to conduct

\footnotetext{
${ }^{9}$ Often, independents are individuals who lost in the primaries to represent their favored party.

${ }^{10}$ We discuss allegations of vote fraud in Appendix A.2.

${ }^{11}$ The average across all 18 countries in the sample was $70 \%$. In the same survey, $35 \%$ of Ugandan respondents said they had themselves been offered incentives to vote in elections (the sample average was $18 \%$ ).
} 
focus groups prior to the beginning of the ACFIM campaign. In addition, before and after the election we interviewed several elected candidates to gather information about their vote-buying operations and how they fund these operations. Finally, in order to better understand the response of candidates to the ACFIM campaign, we conducted a survey of 438 brokers after the election. This section briefly summarizes the findings from this qualitative work.

The focus groups highlighted the extent of vote buying and its importance for winning elections. While focus group participants agreed that some voters may choose to "eat widely but vote wisely," i.e., to take money for their vote but then vote for their preferred candidate, they also highlighted the importance of the reciprocity norm: a large share of voters reciprocate gifts with their vote since money "softens people's hearts." Votes are traded in exchange for cash or basic consumption goods (such as soap, sugar, or salt), which tend to be distributed in the weeks preceding the election.

In practice, these gifts are not handed out by the candidates themselves, but by political brokers who are typically well-known and well-connected figures in the community. An NDI survey of 185 elected MPs after the intervention reports that all respondents had brokers in the 2016 election. Brokers are not only responsible for handing over gifts to voters, but they also target reciprocity-minded voters and make sure that gift recipients vote as instructed on election day. $73 \%$ of the brokers we interviewed reported being confident that voters who accept gifts do vote for the candidate they represent. In addition, $30 \%$ of brokers report transporting voters to the polls, and $28 \%$ of brokers report casting the ballot on behalf of their clients, who pretend to be illiterate so that the broker can enter the polling booth with them. Candidates hold regular meetings with their brokers, and they monitor performance by assessing electoral outcomes and voter turnout in each broker's area of work. All of these aspects point to the important role of local brokers in carrying out effective vote buying campaigns.

\section{Experimental design}

\subsection{Description of the intervention}

We partnered for this experiment with the Alliance for Election Campaign Finance Monitoring (ACFIM), a coalition of 13 Ugandan civil society organizations (CSOs). ACFIM relies on its network of local activists across the country to monitor political spending and to advocate for greater transparency in the financing of electoral campaigns. ACFIM implemented their anti-vote buying campaign in JanuaryFebruary 2016 in 53 districts, about half the country. The design of the campaign was influenced by ACFIM and NDI's past interventions, by a survey of Ugandan MPs on campaign financing, and by the focus groups described earlier.

The campaign sought to change actual and perceived norms of behavior around vote buying. Information about the negative consequences of vote buying that ACFIM activists disseminated through leaflets, initial village meetings and automated phone calls, as well as resolutions during subsequent village meetings, were meant to establish a refusal norm around gift acceptance. Community discussions and resolutions aimed to foster a sense that vote selling, and thus deviating from the collective commitment, would be socially sanctioned. A central message of the campaign was that vote selling 
undermined the delivery of public services to the community, and therefore entailed individual and collective costs. With this message, the campaign also tried to weaken the reciprocity norm associated with vote buying. Politicians offering gifts in exchange for votes would no longer be perceived as generous caretakers, but rather be associated with bad outcomes for individuals and the community as a whole.

The campaign took place in the final five weeks before the election, when most vote-buying transactions take place, and involved several stages in each selected village. First, in January 2016, local ACFIM activists delivered leaflets via door-to-door canvassing to all households in treated villages. The leaflets explained in simple terms the costs and risks of vote buying to their communities in terms of the potential loss of access to public services. In the process of delivering the leaflets, activists also invited households to participate in village meetings to discuss vote buying. The content of the leaflets was approved by the Electoral Commission and was entirely non-partisan. The leaflets contained a cartoon alongside the following message (in the language spoken by the community): ${ }^{12}$

“You wouldn't sell your future, you wouldn't sell your village's future. So, why sell your vote? Stand together with your village, and don't sell your vote. It is your chance to demand a better future!"

A sample leaflet in English, in Figure 1, shows individuals first receiving money from a candidate for their votes, and then seeing their request for a health center denied on the ground that the candidate had already bought them off. These illustrations and the caption embody the main messages behind the ACFIM campaign, which were reemphasized during the complementing components of the intervention. First, individuals who sell their votes are unlikely to be later able to demand public services from the candidates to who they sold their votes. Second, community coordination is important to fight vote buying and the associated lack of access to public services.

Following the leaflet distribution, three village meetings were organized to discuss vote buying. Each meeting was facilitated by a local ACFIM activist while a second activist took notes. The first meeting focused on introducing the campaign, discussing the leaflet, and gathering participants' thoughts and experiences on vote buying. The second meeting was designed to provide an avenue for deliberation about how to collectively tackle vote buying. Finally, during the third meeting, ACFIM activists invited the community to collectively commit to refuse offers of gifts or money in exchange for their votesan invitation to enforce the refusal norm. In communities that committed to renouncing vote buying, ACFIM activists then placed posters throughout the village indicating the village is a "no vote-buying village."

Finally, on the eve of election day, individuals who had attended the village meetings and provided their phone number received automated phone calls reminding them about the harms associated with vote buying. The calls included the following message (in the appropriate local language):

"Hello! This is an important message from ACFIM. We are calling you to ask you not to sell your vote. You might think it is harmless to accept some small money or goods from politicians during election campaigns, but this will affect the future of your whole community. Do you not want good hospitals,

\footnotetext{
${ }^{12}$ Eighteen different languages were used in the campaign: Acholi, Alur, Aringa, Ateso, Kumam, Langi, Lubwisi, Luganda, Lugbara, Lusoga, Madi-Moyo, Ngakarimojong, Rufumbira, Rukhozo, Rukiga, Runyankole, Runyoro, and Rutoro.
} 


\section{You wouldn't sell your soul. You wouldn't sell your village's future. WHY SELL YOUR VOTE?}
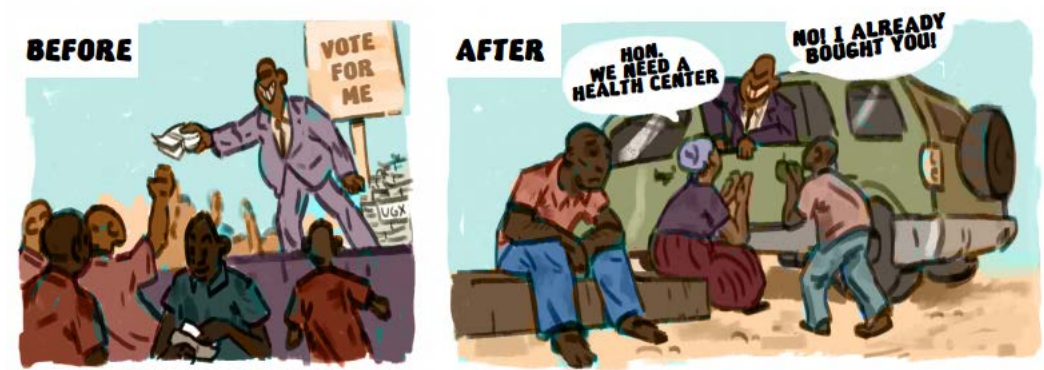

\section{Stand together with your community and don't sell your vote. It is your chance to demand a better future!}

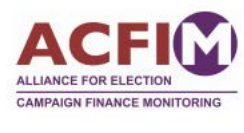

Figure 1: ACFIM leaflet

good roads, good schools for your children? When you ask for these services after elections, the politician who wins through buying votes will tell you "I bought your vote, therefore do not bother me by asking me for more things." Don't let your community down. Don't let your country down. Don't sell your vote!"

\subsection{Experimental sample}

Our experimental sample includes 918 parishes where ACFIM had some presence before the intervention. This sample is spread across the country, including 110 parliamentary constituencies in 53 Ugandan districts. Within these parishes were 2,796 eligible villages served by 1,603 polling stations. "Eligible" villages are villages where a local ACFIM activist resided or was well known by the villagers prior to the intervention. ${ }^{13}$ Thus our experimental sample is not a representative sample of Ugandan villages. Parishes typically have several ineligible villages. These are formally outside our experimental sample, as we performed the randomization among eligible villages only. ${ }^{14}$ However, to increase our power to estimate spillover effects of the campaign, we also collected data in an additional 1,399 ineligible villages located in the same 918 parishes. We return to these data below.

\subsection{Randomization}

To select which villages would be treated with the anti-vote-buying campaign, we used a randomized saturation design similar to the one in Baird et al. (2018). We randomly varied the level of saturation of treatment at the level of a parish. Because the campaign could only take place in areas where ACFIM activists had a local presence at baseline, the randomized saturation level is defined in terms of eligible

\footnotetext{
${ }^{13}$ Due to cultural issues, it is very hard for an individual to conduct this type of intervention in villages where she is perceived as an "outsider." As ACFIM members explained it to us, activists had to be "sons of the soil" for villagers to listen to them.

${ }^{14}$ Appendix A.4 provides additional details on sampling and external validity.
} 
villages. The fraction of eligible villages in a parish ranged from 3\% to $100 \%$, with an average of $48 \%$. Accounting for the variation in the number of voters registered at each polling station, the fraction of eligible voters ranged from $1 \%$ to $100 \%$, with an average of $54 \%$. All our specifications control for the baseline level of ACFIM presence, as described in our pre-analysis plan.

First, we randomly assigned parishes into three roughly equally-sized groups of parishes: a pure control group (no treatment), a partial-saturation treatment group (50\% of eligible villages assigned to treatment), and a high-saturation group (100\% of eligible villages assigned to treatment). Among the 918 parishes and 2,796 eligible villages, we randomly selected 535 parishes (containing 1,427 eligible villages) for partial- or high-saturation treatment. The remaining 383 parishes were assigned to the pure control group. To illustrate, consider a parish with 8 equally-sized villages, of which 4 have ACFIM activists. If this parish were assigned to the high-saturation group, this would mean that all 4 of the eligible villages would be treated (equivalent to $50 \%$ "true" saturation). If assigned to partial saturation, then a randomly selected 2 of the 4 eligible villages would be treated ( $25 \%$ true saturation). We stratified randomization at the parish level along baseline measures of partner presence (defined in terms of the number of voters covered), parish-level voter population, and support for the incumbent political party in the 2011 presidential election. ${ }^{15}$

Second, within the partial-saturation parishes we assigned half the eligible villages to treatment. To maximize our power when looking at electoral results at the polling-station level, we randomized villages to treatment or control status as a function of the randomized status of their polling stations. All eligible villages that voted at treated polling stations were selected to receive the ACFIM campaign. None of the villages falling under control polling stations were selected to receive the campaign. This creates an integer problem if all eligible villages vote at a single polling station. If only one polling station was eligible for treatment in a parish, it was either fully treated (with 50\% probability) or it was a control (with $50 \%$ probability). ${ }^{16}$

In addition to standard intent-to-treat estimates of treatment assignment, this design also allows us to identify spillover effects on the untreated villages in treated parishes. This category of spillover villages includes untreated eligible villages in the partial-saturation parishes as well as ineligible villages in both the partial- and high-saturation parishes. We estimate spillover effects by comparing spillover villages to villages in control parishes.

Furthermore, the design allows us to recover estimates of how the direct estimates and spillover estimates vary with parish saturation. The spillover effects could differ substantially with such saturation. For instance, if a sizable share of villagers resists vote buying, political candidates or their brokers may be forced to change vote-buying tactics as well as other campaign strategies.

Importantly, our design rests on the assumption that spillovers are limited across parishes. There

\footnotetext{
${ }^{15}$ Specifically, a stratum was defined by the interaction of quartile of partner presence, quartile of the voter population, and quartile of district-level NRM support (64 strata in total).

${ }^{16}$ To fix this concept clearly, we can return to our 8 village (4 with ACFIM presence) parish example from before. Imagine that there are 4 polling stations in this parish, each covering 2 villages. If that parish was assigned to the partial saturation treatment, there would be no problem (1 eligible, treated polling station, 1 eligible, untreated polling station, and 2 ineligible, untreated polling stations). However, if there were only 2 polling stations ( 1 with all 4 of the ACFIM villages, 1 with none), then this parish would either be assigned to have its 1 eligible polling station treated (which is equivalent to high saturation treatment) or its 1 eligible polling station untreated (which is equivalent to being in the control).
} 
are several reasons to believe that this is a reasonable assumption. First, the intervention took place only a few weeks before the election, leaving little time for candidates to reallocate resources across brokers in different parishes. There were no such instances reported in our interviews with brokers. Second, brokers that received resources from candidates with which to buy votes had no incentive to communicate to candidates that they should expect a lower electoral return on those funds. Consistent with this lack of reporting incentives, brokers working for incumbent candidates reported that they expected the ACFIM campaign to have no effect.

\subsection{Compliance and quality of implementation}

Funding and logistical delays meant that ACFIM implemented the intervention later and more hastily than they originally anticipated, but qualitative data from ACFIM notetakers and our own survey data suggest a reasonably high level of treatment compliance and quality of implementation.

ACFIM estimates that the leaflet was received by 67,374 households across 1,427 targeted villages, or approximately $41 \%$ of the total population in these villages (there were 422,110 registered voters in total across all treatment villages). ${ }^{17}$ Following the leaflet drop, an estimated 62,566 households participated in at least one meeting, which averaged 30 participants. ACFIM also sent 21,390 posters (15 per village) to treatment villages. Finally, a total of 32,674 automated calls were made on the eve of the election (i.e., on February 17, 2016, between 5pm and 8pm) to individuals who provided their phone number to ACFIM at one of the meetings. According to administrative data provided by the implementing company, $18,451(56 \%)$ of these calls were answered.

In general, ACFIM's administrative notes suggest that the activists implemented the meetings in accordance with their training and the meeting scripts. ${ }^{18}$ The survey data we collected after the campaign also points to a successful campaign implementation. Table 1 reports control means and treatment effects on various implementation measures, including treatment effects, spillover effects, and the effects of parish-level saturation. We provide a detailed discussion of these effects and the corresponding specifications in section 5, but we highlight a few basic compliance statistics here. Respondents in treatment villages were 34 percentage points more likely to report observing representatives from an NGO conducting an anti-vote-selling campaign and receiving leaflets with an anti-vote-selling message, 29 percentage points more likely to have attended a community meeting to discuss vote buying, and 3 percentage points more likely to have received a automated phone call against vote selling. ${ }^{19}$

\footnotetext{
${ }^{17}$ This percentage is estimated from a back-of-the-envelope calculation based on the following figures. Based on the 2014 Ugandan census, the average household had 4.7 members and the fraction of the population under 18 (thus ineligible to vote) was $55 \%$. We validated this estimate using our survey, which found that 37 percent of individuals in treatment villages said they received a leaflet.

${ }^{18}$ Our notes indicate that the facilitators followed the script in almost all of the meetings. For the first meeting, note takers indicate that $73 \%$ introduced the campaign and discussed the leaflet content, while $51 \%$ included the sharing of participants' views about vote buying and selling. The second meeting was a transition meeting designed to provide an avenue for a collective deliberation on vote buying. There is more variation in what note takers indicated, but all meetings are consistent with the intended purpose. For the third meeting, note takers indicated that in $61 \%$ of cases the conveyed goal was to deliberate on and arrive at a community resolution against vote buying.

${ }^{19}$ We expected a smaller effect on calls received, since calls were only made to individuals who voluntarily shared their phone numbers during the meetings organized by ACFIM in treated villages, and the overall pick-up rate was low.
} 
The control means in Table 1 are nonzero, suggesting that representatives from other organizations were active, as one would expect, but the absence of any sizable or statistically significant effects on spillover villages suggest that these villages were generally not experiencing the ACFIM campaign directly. All this is consistent with ACFIM administrative notes, which indicate that participants at the village meetings were almost all from that village, with an average of fewer than 2 in 30 attendees being from another village. ${ }^{20}$

Activists' notes highlight that the meetings were relatively successful at guiding communities to arrive at a village-wide resolution against vote buying, which occurred in $65 \%$ of treatment villages. Their notes further indicate that, in $27 \%$ of these cases, the village resolved to "eat widely and vote wisely"-i.e., to take the money offered for their votes but to ultimately vote for the candidate they deemed best. While there was not perfect compliance, these numbers suggest that the intervention might have been successful at facilitating community coordination against vote selling.

Lastly, activists' notes also suggest that in $70 \%$ of the village meetings there was at least one influential individual present who was likely to engage in or mediate vote-buying activities, namely a local official, an MP, an MP candidate, or a political broker. In $74 \%$ of the cases where at least one such individual was present, note takers reported that he or she tried to influence the meeting by making arguments in favor of vote buying or against the purpose of the anti-vote-buying campaign. Such high participation rates by those with a vested interest in vote buying indicate that these individuals were aware of the ACFIM campaign and potentially felt threatened by it.

\section{Data}

\subsection{Administrative Data}

We use official electoral results obtained from the Ugandan Electoral Commission at the lowest possible level, the polling station. We use this data for the presidential and the parliamentary elections conducted in February 2016 for 1,585 of the 1,603 (99\%) polling stations in our experimental sample. ${ }^{21}$ We also use data on turnout and the incumbent's vote share in the previous general election, conducted in 2011, available for $98 \%$ of polling stations in our sample. We discuss the reliability of the electoral data in Appendix A.2.

\subsection{Survey data}

We conducted an endline survey of 28,454 Ugandan citizens following the ACFIM campaign and the general election. The survey started on March 2, 2016, and ended on July 19, 2016. The survey involved three different questionnaires: one for registered voters, one for a "key informant" in each village, and a local market survey of the prices of goods commonly used for vote buying as well as other goods.

\footnotetext{
${ }^{20}$ Importantly, the share of outsiders across meetings was constant, which lessens the concern of a cumulative effect characteristic of significant spillovers.

${ }^{21}$ Due to discrepancies in local names and spellings, we were unable to match $1 \%$ of polling stations in our sample with the official electoral data.
} 


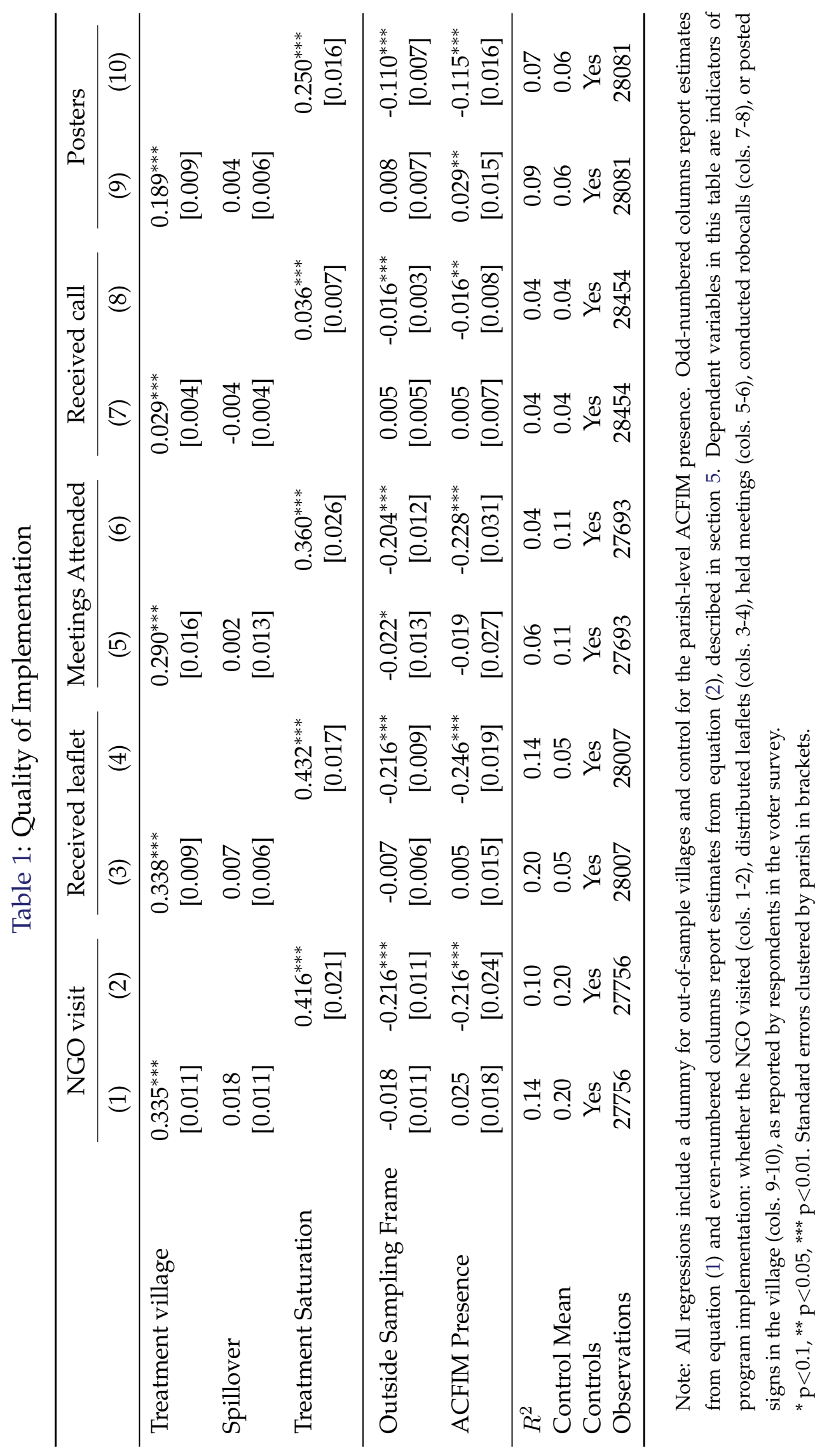


The survey of registered voters, which contains many of the outcomes we examine in section 6, collected detailed data on vote selling behavior, electoral behavior, and attitudes towards vote buying. The data on cash and gifts received was collected across different candidates (and the brokers who operated for them), allowing us to separately examine vote selling behavior by these different candidates. Survey respondents were randomly sampled from the official voter register in each village, stratifying into four categories by age (above or below the median for Ugandan voters) and gender. ${ }^{22}$ All respondents were 18 or over, registered to vote, and lived in the village.

\subsection{Qualitative data}

To provide insights into the content of community meetings held as part of the campaign, we use data collected by ACFIM during the three village meetings. The ACFIM note-taker had to fill in basic information about the meeting, which included the start time, end time, location, estimate of the number of participants from the village and from outside the village, and the presence of influential individuals likely to engage in or mediate vote-buying activities (local officials, MPs, candidates or brokers). The note taker also answered questions addressing whether the facilitators conducted the meetings as specified during training and in the meeting scripts, the views of the community about the effect of vote buying and possible solutions to eliminate the practice, and their perceptions of how likely communities were to vote on a resolution against vote buying and whether they ultimately did.

After the campaign, we also conducted structured interviews with a non-representative sample of 438 brokers across Uganda. Sampling was restricted to accessible locations and stratified by a measure of vote buying in the village, since we were interested in understanding the response of brokers across areas of different vote-buying intensity. We use this data for descriptive purposes only.

\section{Empirical framework}

\subsection{Estimation}

We designed our research and set up empirical specifications to estimate the treatment effects, spillover effects, and saturation effects of the ACFIM campaign. Our baseline equation is the following intent-totreat (ITT) specification:

$Y_{i v p}=\alpha_{0}+\alpha_{1}$ Treatment $_{v p}+\alpha_{2}$ Spillover $_{v p}+\alpha_{3}$ ACFIM vip $+\alpha_{4}$ ACFIM Presence $_{p}+\Omega X_{i v p}+\varepsilon_{i v p}$

where Treatment $v$ is an indicator for assignment to the intervention in village $v$ in parish $p$; Spillover $_{v p}$ is an indicator that village $v$ is untreated but located in parish $p$ that is treated; $A C F I M_{v p}$ is an indicator that village $v$ is an eligible village; ACFIM Presence $_{p}$ is the baseline presence of ACFIM activists in the parish, ${ }^{23}$ and $X_{i v p}$ is a vector of individual-level controls from the survey and parish-level controls

\footnotetext{
${ }^{22}$ The voter register for the 2016 election was available for all but two parishes in our sample. In those cases, we used the voter register from the 2011 election. For villages with fewer than 40 individuals listed in the voter register, we included all individuals, irrespective of age or gender.

${ }^{23}$ We measure $A C F I M$ Presence $p$ as the fraction of voters in parish $p$ that live in an eligible village.
} 
from the electoral data. ${ }^{24}$ The $A C F I M_{v p}$ term is an indicator for being part of our experimental sample, which we include in all specifications since the dataset includes 1,399 out-of-sample villages in treated parishes (ineligible for treatment because of the lack of baseline ACFIM presence). This term accounts for variation in Treatment $_{v p}$ and Spillover $_{v p}$ that comes from non-randomly assigned ACFIM presence. We focus on the treatment and spillover estimates, $\alpha_{1}$ and $\alpha_{2}$. All our tables also report coefficients on $A C F I M_{v p}$ and ACFIM Presence $_{p}$, but these are not causally identified. We use the same specification for regressions conducted using the polling station-level data. In this case, observations are at the level of polling station $j$ within parish $p$.

To estimate how the effects of the ACFIM campaign vary with the level of treatment saturation (at the level of the parish), in every table we report results from the following equation:

$$
Y_{i v p}=\gamma_{0}+\gamma_{1} \text { Saturation }_{p}+\alpha_{3} \text { ACFIM }_{v p}+\alpha_{4} \text { ACFIM_Presence } p+\Omega X_{i v p}+\varepsilon_{i v p}
$$

where Saturation $_{p}$ is defined as the fraction of voters in parish $p$ that are being treated (i.e the intensity of the treatment at the parish level). As in equation (1), the terms $A C F I M_{v p}$ and ACFIM Presence $_{p}$ account for variation in Saturation $_{p}$ that comes from non-randomly assigned baseline ACFIM activist presence in a parish, giving us causal estimates for saturation. $\gamma_{1}$ then measures the average effect of random treatment saturation across treatment and spillover villages.

Note that we did not specify equation (2) in our pre-analysis plan. We present estimates from this equation (as opposed to from equation (3) which we explain next) throughout for ease of exposition and because we consider the main effect of treatment saturation to also be of interest. Note that this regression specification assumes a constant effect of saturation on both treated and spillover villages. As our results make clear, this is empirically the case for most outcomes. We discuss later why this may have been the case.

Finally, to estimate how treatment and spillover effects vary with saturation, we also run the following linear saturation model:

$$
\begin{aligned}
Y_{i v p}= & \beta_{0}+\beta_{1} \text { Treatment }_{v p}+\beta_{2} \text { Spillover }_{v p}+ \\
& \beta_{3} \text { Treatment }_{v p} \times \text { Saturation }_{p}+\beta_{4} \text { Spillover }_{v p} \times \text { Saturation }_{p}+ \\
& \beta_{5} \text { ACFIM }_{v p}+\beta_{6} \text { ACFIM Presence }_{p}+\beta_{7} \text { ACFIM }_{v p} \times \text { ACFIM Presence }_{p}+\text { PXX }_{i v p}+\varepsilon_{i v p}
\end{aligned}
$$

The two main coefficients of interest here are $\beta_{3}$ and $\beta_{4}$, indicating how the treatment and spillover effects, respectively, change with treatment saturation at the parish level. ${ }^{25}$ Note there is no main effect

\footnotetext{
${ }^{24}$ These controls include, from the survey data, the age, years of education, and marital status of the respondent, whether the household owns any land, the number of adults and children in the household, an index of asset ownership (as defined in Appendix A.1), as well as occupation, ethnicity, and religion dummies. From the electoral data, we include the 2011 turnout, the NRM and FDC vote shares in the 2011 presidential election, the 2011 fraction of the vote received by the winning parliamentary candidate, and the number of registered voters in 2016.

${ }^{25}$ Equation (3) includes a minor deviation from pre-specified equation (2) in our pre-analysis plan, which had two additional right-hand side terms $\left(\right.$ ACFIM Presence Preatment $_{v p}$ and $A C F I M$ Tresence $_{p} \times$ Spillover $\left._{v p}\right)$ but did not include the $A C F I M$ Presence $_{p} \times \beta_{6} A C F I M_{v p}$ interaction. The results obtained from both specifications are qualitatively similar, but equation (3) above is the correct specification since the previously included terms captured some of the relevant (exogenous) variation and thus should not be included as controls.
} 
of Saturation $_{p}$ in this specification since all control parishes have zero saturation by design. $\beta_{1}$ recovers the Treatment on the Uniquely Treated or TUT, which is the Intent-to-Treat effect of the campaign on a theoretical sole individual offered treatment within a treated parish (Baird et al., 2018). In other words, $\beta_{1}$ measures the direct effect of the campaign measured at the theoretical point of zero saturation. $\beta_{1}$ and $\beta_{3}$ together account for the total treatment effect of the campaign: $\beta_{1}$ captures the TUT while $\beta_{3}$ captures spillovers on the treated. $\beta_{2}$ in this specification does not have a meaningful interpretation. Since the corresponding structural parameter is zero by definition, as Baird et al. (2018) explain, a test of $H_{0}: \hat{\beta}_{2}=0$ provides a test of the assumption that spillovers are linear. ${ }^{26}$ Estimates from equation (3) are reported in Appendix Tables A19 through A24 for our main outcomes of interest, and we only discuss them whenever they provide additional insights beyond the estimates from equation (2).

\subsection{Addressing multiple outcomes and comparisons}

We sought to reduce the risks of false discovery or cherry-picking results in a number of ways. First, we pre-specified our hypotheses, estimation framework, and outcomes in a pre-analysis plan. ${ }^{27}$ Second, we singled out one primary set of outcomes of interest: survey-based reports that candidates gave cash or goods to the respondent or other villagers, which we use to analyze the direct treatment and the spillover effects of the ACFIM campaign on vote buying. In addition, we pre-specified a number of secondary outcomes of particular policy relevance, including vote shares and turnout, measures of the aggregate supply and demand for votes at the village level, attitudinal outcomes, and measures of campaigning. Finally, we reduced the number of primary hypotheses to test by combining them into mean effects indexes of all outcomes in that family. ${ }^{28}$

\subsection{Randomization balance}

Treatment is balanced along covariates. We present randomization checks in Appendix Tables A2 through A7. We use a range of baseline or time-invariant variables from the voter survey, key informant survey, and official electoral data. We provide a detailed description of these variables in Appendix 1. We regress these variables on our two main specifications, namely equations 1 and 2 from section 5.1, and report all the coefficients from these specifications. Of 99 coefficients (from 66 regressions), only 9 (9\%) have a p-value less than 0.1 - almost exactly what should have occurred as a result of chance. Nonetheless, our main results include and are thus robust to adding controls for baseline covariates.

\footnotetext{
${ }^{26}$ Across Tables A19-A24, we cannot reject that $\hat{\beta}_{2}=0$ in 23 out of 25 specifications.

${ }^{27}$ See https: / /www. socialscienceregistry.org/trials/965, archived on December 18, 2015.

${ }^{28}$ We take averages of our outcome measures, coded to point in the same direction, akin to the approach by Kling et al. (2007). Component variables are first standardized, then averaged, then standardized again to have mean zero and unit standard deviation in the control group. We do this first for all variables from the voter survey, and then for all the variables in the key informant survey, and then average the two. This gives the two sources of data equal weight.
} 


\section{Results}

We start by summarizing qualitative accounts from our debriefing of ACFIM activists and interviews with brokers. While the qualitative evidence must be interpreted with caution, we believe that it provides interesting insights into the context and mechanisms behind our quantitative results. Section 6.2 provides an overview of the main experimental results. We then turn to a detailed description of treatment effects of the campaign on electoral outcomes, social norms, vote buying, and campaigning.

\subsection{Qualitative results}

Reports from ACFIM activists point to the intervention's inability to establish a refusal norm around gift acceptance, as well as its apparent success at weakening reciprocity. This undermined the electoral prospects of incumbents, who engaged in the bulk of vote buying at baseline, and incentivized challenger candidates to compete in areas previously dominated by incumbents.

While there are isolated stories of voters refusing gifts for their vote, or even taking cash from the incumbent and handing it over to a challenger candidate, most accounts indicate that treated voters were likely to take the money but then vote for the candidate that they thought would best represent their views. One broker interviewed after the campaign stated that "voters didn't stop accepting gifts, (but) voted for the candidate of their choice," while many mentioned that voters started to "eat widely and vote wisely." Brokers operating for incumbent candidates did not perceive this change in norms, and widely expected that the intervention would have little effect since voters continued to accept gifts.

On the other hand, brokers serving challenger candidates perceived the intervention as an opportunity since existing vote buying arrangements tended to benefit incumbents. In total, thirty percent of the brokers we interviewed expected voters would stop reciprocating gifts for their votes and start voting for their preferred candidate. Eighteen percent of brokers mentioned that challengers started operating in villages where they previously did not operate, conducting visits and distributing leaflets with campaign promises. For example, one broker explained that "brokers, mostly from opposition parties, went to villages to start campaigning after getting information about the anti-vote-buying campaign."

Overall, 50\% of the brokers we interviewed reported that they started to campaign on policies after the ACFIM campaign. Such campaigning covered a range of topics, including improved roads, local public service delivery, education, health, and better economic opportunities. For example, one broker mentioned that "candidates switched to campaigning on policy-based issues like improving roads and availing the community with boreholes." However, even for challengers, policy campaigning still appeared to be tied to vote buying. As clearly explained by a broker, "we were looking for votes addressing policy issues but at the same time buying votes because nowadays, in Uganda, people are not really used to talking to them without giving them something." Brokers indicate that challenger candidates then also commenced to buy votes in areas where they were not operating prior to the intervention. 


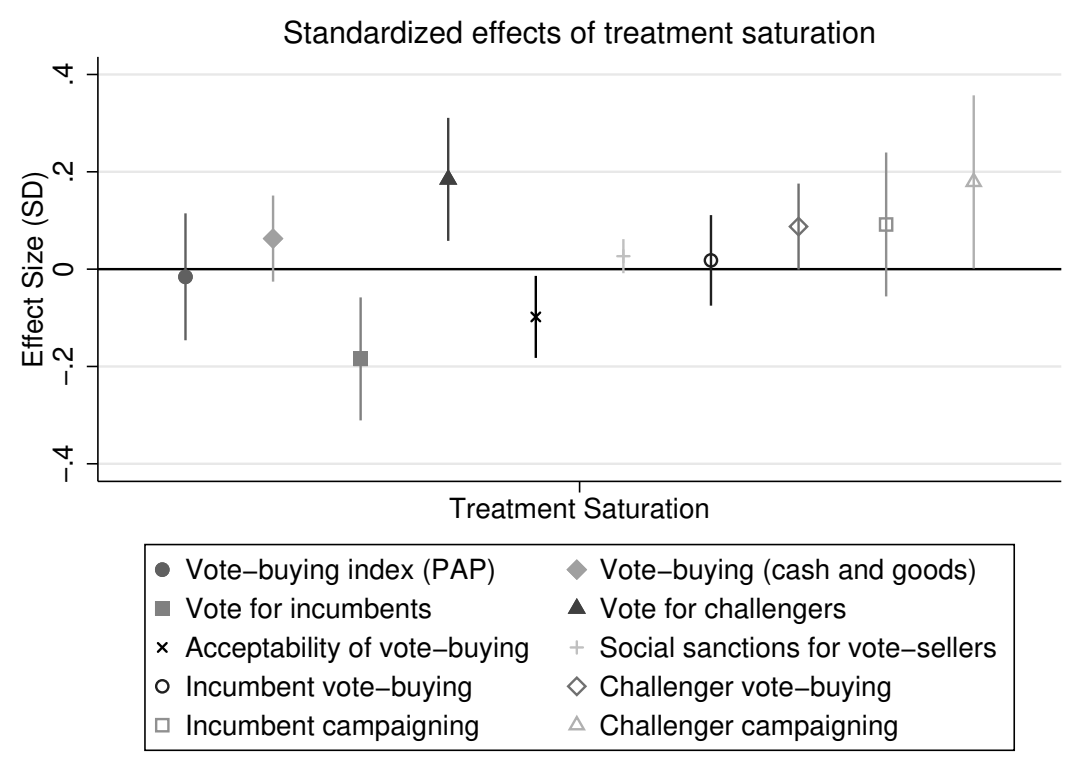

Figure 2: Main treatment effects

Note: This figure reports estimates from equation (2). The bars indicate $95 \%$ confidence intervals.

\subsection{Overview of quantitative results}

Consistent with these qualitative accounts, Figure 2 summarizes the effect of the intervention on standardized indexes of our main outcomes of interest. These coefficients are also reported in Table A8. Since program effects in treated and spillover villages almost always go in the same direction, for simplicity Figure 2 focuses on the treatment effects of parish saturation (from equation (2)), which captures the campaign's effect in both types of villages.

The first estimate in Figure 2 is the coefficient on our pre-specified index of vote buying. This includes cash and gift acceptances as well as several outcomes capturing perceptions of vote buying in the village. The second estimate looks only at an index of reported acceptance of cash and goods. Neither estimate suggests that the campaign achieved its goal of reducing vote buying. Both effects are very close to zero and are indistinguishable from each other. In the remainder of the analysis, we focus on the second index or its constituent elements since this allows us to disaggregate vote buying across different types of candidates.

Subsequent estimates in Figure 2 examine voting outcomes in the 2016 presidential and parliamentary elections. The third and fourth coefficients capture the effect of treatment saturation on self-reported electoral support for incumbent and challenger candidates, respectively. These results show that the campaign significantly reduced electoral support for incumbents while increasing support for challengers. Results obtained using the official electoral data, which we present in section 6.3, deliver similar albeit noisier findings.

The next two coefficients suggest that these electoral effects are explained in part by a change in social norms among voters exposed to the ACFIM campaign. The fifth coefficient looks at whether 
the campaign changed perceptions of the refusal norm against vote buying. The dependent variable is a pre-specified index of the perceived fraction of village residents who would sell their vote at given price points (ranging from 1,000 to 50,000 Ugandan shillings (UGX)) and of the perceived acceptability of selling one's vote in a vignette experiment. The campaign had a negative, significant effect on this outcome, consistent with a change in perceptions of the acceptability of vote buying. The sixth coefficient measures the treatment effect on voters' perceptions of the likelihood that vote selling would result in social sanctions. This coefficient is positive and statistically significant. We describe this set of results in more detail in section 6.4.

The remaining coefficients examine how changes in the (vote buying and campaigning) tactics of candidates may have also contributed to the electoral effects documented above. The seventh and eighth coefficients reported in Figure 2 are treatment effects on vote buying (offers of cash or goods) by incumbents and challengers. The coefficient on vote buying by incumbents is a fairly precise zero, while the coefficient on vote buying by challengers shows a significant increase in vote buying by those candidates. Consistent with the qualitative accounts discussed above, the last two coefficients provide evidence for an increase in campaigning, particularly by challengers, in heavily treated parishes. The campaign's effects on vote buying and campaigning are discussed in sections 6.5 and 6.6, respectively.

We next describe our results in more detail, discussing treatment effects for treated and spillover villages. We start by assessing the ultimate impact of the intervention on voting outcomes. We then provide evidence that this effect is explained by the response of agents on both sides of the market for votes: voters, who increased their social sanctioning of vote sellers and were less likely to reciprocate vote buying exchanges; and candidates, who re-optimized their vote-buying and campaigning efforts in response to the ACFIM intervention.

\subsection{Effects on electoral outcomes}

Table 2 reports treatment effects on candidate vote shares as well as voter turnout. We first report treatment effects on the vote share accruing to incumbent candidates in the presidential and parliamentary races. The corresponding estimates for challenger candidates are identical but oppositely signed to the incumbent effects, and are therefore omitted. Regressions conducted using the survey data are run at the voter level, while regressions using the electoral data are run at the polling-station level. We report the coefficients from equation (1) in odd-numbered columns and those from equation (2) in even-numbered columns. All outcomes are standardized and pooled across the presidential and parliamentary races.

As a cautionary note, whether one should put more weight on the (self-reported) survey data or the administrative data is a priori unclear. The survey data could be subject to social desirability bias. However, if anything, this bias should be directed towards incumbents, and thus is not a source of major concern given our findings. Moreover, since there is some measurement error in the administrative data because of treated polling stations potentially containing some voters from non-treated villages, the survey data may yield more precise estimates of actual voting behavior. Lastly, there were allegations of vote fraud in the 2016 elections. We discuss and dismiss this possibility in Appendix A.2.

Overall, the estimates across both data sources suggest that the ACFIM campaign affected the elec- 
toral performance of candidates to the detriment of incumbents, and consequently to the benefit of their opponents. Measures of incumbent support are constructed using the self-reported survey data in columns 1-2, and using the electoral administrative data in columns 3-4. The survey data yields statistically significant effects in treated and spillover villages as well as in high-saturation parishes relative to control parishes. Incumbent candidates suffered a loss of around $0.063 \mathrm{sd}$ in treated and spillover villages, and of $0.185 \mathrm{sd}$ in fully treated parishes. The magnitude of the coefficients is similar when using the administrative data, but we are less powered to assess the significance of these coefficients. In addition, the estimate of the average spillover effect becomes close to zero and statistically insignificant.

Columns 5-6 of Table 2 present treatment effects on voter turnout, measured using administrative data at the polling-station level. Turnout in the administrative data was $67 \%$ for the presidential election and $69 \%$ for the parliamentary elections. ${ }^{29}$ Results suggest a moderate positive effect of the ACFIM campaign on voter turnout-potentially an outcome of the increase in campaigning activities observed among challengers, which we document below. The effect size is approximately 0.07 sd for treated villages but falls short of statistical significance, and is $0.15 \mathrm{sd}$ and statistically significant for fully treated parishes.

\subsection{Effects on perceptions of social norms around vote buying}

We next explore the extent to which the ACFIM campaign succeeded in: (i) establishing a refusal norm against vote buying, (ii) weakening the reciprocity norm associated with vote buying, and (iii) increasing expectations of social sanctions for vote selling. We explore these issues using detailed survey data on attitudes towards vote selling and its consequences. Table 3 presents the resulting estimates.

While (by revealed preference) only a change in actual vote selling behavior provides sufficient evidence of a change in the refusal norm, our endline survey also collected a set of proxies for perceptions of this norm. Perceptions matter since they should have affected a voter's fear of social sanctions and thus her willingness to sell a vote. In columns 1-2, we report treatment effects on a pre-specified index measuring people's perceptions of the community's willingness to accept vote-buying offers. This index has the following components. First, we asked respondents to estimate the fraction of voters in the village whom they expected would sell their vote for prices ranging between 1,000 UGX and 50,000 UGX (roughly USD 26c to \$13 in nominal terms). Second, we conducted a vignette experiment that asked how acceptable it would be for a hypothetical hard-working individual in financial distress to sell his vote to provide for his household. The dependent variable in columns 1-2 combines standardized answers to these questions. We use this measure as a proxy for the level of perceived compliance with the refusal norm. ${ }^{30}$ We find that the ACFIM campaign significantly decreased the perceived acceptability of vote selling by $0.061 \mathrm{sd}$ in treated villages and 0.098 in fully treated parishes.

We then turn to the voters' perceptions of the social costs of vote buying. A negative change in these

\footnotetext{
${ }^{29}$ We do not report results on self-reported turnout given the implausibly high turnout in our survey data (95\% for the presidential election and $93 \%$ for the parliamentary election).

${ }^{30} \mathrm{~A}$ benefit of asking about other voters' behavior, as opposed to an individual's own behavior, is to minimize social desirability problems. This behavior captures not only the erosion individual of reciprocity but also social sanctioning resulting from social coordination against vote selling in treated villages.
} 
Table 2: Effects of the Campaign on Electoral Outcomes

\begin{tabular}{|c|c|c|c|c|c|c|}
\hline & \multicolumn{4}{|c|}{ Standardized index: Incumbent Support } & \multicolumn{2}{|c|}{ Standardized index: Turnout } \\
\hline & $(1)$ & $(2)$ & (3) & $(4)$ & (5) & (6) \\
\hline & \multicolumn{2}{|c|}{ Survey Data } & \multicolumn{2}{|c|}{ Electoral Data } & \multicolumn{2}{|c|}{ Electoral Data } \\
\hline Treatment & $\begin{array}{c}-0.063^{*} \\
{[0.034]}\end{array}$ & & $\begin{array}{c}-0.071 \\
{[0.049]}\end{array}$ & & $\begin{array}{c}0.067 \\
{[0.043]}\end{array}$ & \\
\hline Spillover & $\begin{array}{c}-0.064^{*} \\
{[0.037]}\end{array}$ & & $\begin{array}{c}-0.005 \\
{[0.052]}\end{array}$ & & $\begin{array}{c}0.026 \\
{[0.048]}\end{array}$ & \\
\hline Saturation & & $\begin{array}{c}-0.185^{* * *} \\
{[0.064]}\end{array}$ & & $\begin{array}{c}-0.171^{*} \\
{[0.096]}\end{array}$ & & $\begin{array}{c}0.151^{*} \\
{[0.090]}\end{array}$ \\
\hline Outside Sampling Frame & $\begin{array}{c}0.005 \\
{[0.031]}\end{array}$ & $\begin{array}{c}0.008 \\
{[0.017]}\end{array}$ & $\begin{array}{c}-0.026 \\
{[0.031]}\end{array}$ & $\begin{array}{c}0.007 \\
{[0.023]}\end{array}$ & $\begin{array}{c}-0.096^{* * *} \\
{[0.037]}\end{array}$ & $\begin{array}{c}-0.117^{* * *} \\
{[0.029]}\end{array}$ \\
\hline ACFIM Presence & $\begin{array}{c}-0.096 \\
{[0.062]}\end{array}$ & $\begin{array}{c}0.002 \\
{[0.067]}\end{array}$ & $\begin{array}{c}-0.256^{* * *} \\
{[0.090]}\end{array}$ & $\begin{array}{c}-0.175^{*} \\
{[0.100]}\end{array}$ & $\begin{array}{c}-0.006 \\
{[0.087]}\end{array}$ & $\begin{array}{c}-0.075 \\
{[0.098]}\end{array}$ \\
\hline$R^{2}$ & 0.09 & 0.09 & 0.49 & 0.49 & 0.34 & 0.34 \\
\hline Controls & Yes & Yes & Yes & Yes & Yes & Yes \\
\hline Observations & 27065 & 27065 & 3657 & 3657 & 3659 & 3659 \\
\hline
\end{tabular}

Note: All regressions include a dummy for out-of-sample villages and control for the parish-level ACFIM presence. Each dependent variable in cols. 1-4 is a standardized index of electoral support at the Presidential and MP level, self-reported from the survey data (cols. 1-2) or collected from the official electoral data (cols. 3-4). The dependent variable in cols. 5-6 is a standardized index of turnout across both races. All indices have mean zero in the control group.

${ }^{*} \mathrm{p}<0.1,{ }^{* *} \mathrm{p}<0.05,{ }^{* * *} \mathrm{p}<0.01$. Standard errors clustered by parish in brackets. 
perceptions should have contributed to weakening reciprocity, since politicians who buy votes would subsequently be associated with bad outcomes for the community. In columns 3-4 of Table 3, we report treatment effects on beliefs that vote buying had negative consequences for the village. Treated respondents changed their attitude towards vote buying and reported a better understanding of its negative consequences as a result of the ACFIM campaign. As it turns out, $89 \%$ of respondents in control village already held the belief that vote selling had negative consequences for their village. Nonetheless, those believing that vote buying is associated with negative consequences for their village increased by $1.5 \%$ in treated villages and by $3 \%$ in fully treated parishes. In columns 5-6, we look specifically at beliefs as to whether vote selling negatively affected services delivered to the community. Here we find substantive effects of $5 \%$ in treated villages and $10 \%$ in fully treated parishes.

Finally, voters reported an increase in expectations of social sanctions as a result of vote selling. This is key to understanding the effects of the ACFIM campaign on social norms since social sanctions are an important way in which coordination against reprehensible practices is enforced by communities. The percentage of respondents who believed that vote-sellers would be socially punished and ostracized was already high prior to the intervention, at $74 \%$ and $57 \%$, respectively. However, these percentages increased significantly, by $3 \%$ and $4 \%$, respectively. The corresponding figures for parish-level saturation are $4 \%$ and $2 \%$ but are not statistically significant.

Table A21 reports treatment and spillover effects by parish saturation and sheds additional light on these results. For perceptions of the social costs of vote buying (columns 2-3 of Table A21), the spillovers on the treated are larger in magnitude than the treatment on the uniquely treated or TUT. This suggests that changes in social norms did spread throughout treated parishes. For measures of social punishment (columns 4-5), the TUT is substantially larger than spillovers on the treated, which if anything are negative. This suggests that coordination did occur in villages directly exposed to the campaign, but not in spillover villages. We use these insights when discussing the interpretation of our main results in Section 7.

\subsection{Effects on vote buying}

Next, we analyze the effect of the ACFIM campaign on vote-buying offers reported by survey respondents, and the manner in which voters acted in response to these offers.

Main results. Table 4 reports the campaign's effects on a pre-specified index of offers of cash and goods in exchange for votes, measured across all candidates running in the presidential and the parliamentary elections (columns 1-2), and disaggregated across incumbents and challenger candidates (columns 3-6). ${ }^{31}$ Specifically, we focus on a standardized index of 4 variables to capture the prevalence of vote buying: whether the survey respondent reported being offered any gift in cash in exchange for votes, the log of the reported amount of cash offered (plus 1 UGX, to avoid dropping zeros), whether the respondent reported being offered goods, and the log of the value of these goods (plus 1 UGX). ${ }^{32}$

\footnotetext{
${ }^{31}$ Here as in the rest of the paper, we focus on these elections because these two offices are the ones that entail the largest access to public funds, and thus resources invested in vote buying.

${ }^{32}$ In our survey data, we collected data on all brokers who approached the respondent to give her a gift in exchange for her vote, as well as the identity of the candidates these brokers were working for. A respondent is coded as being offered a gift
} 


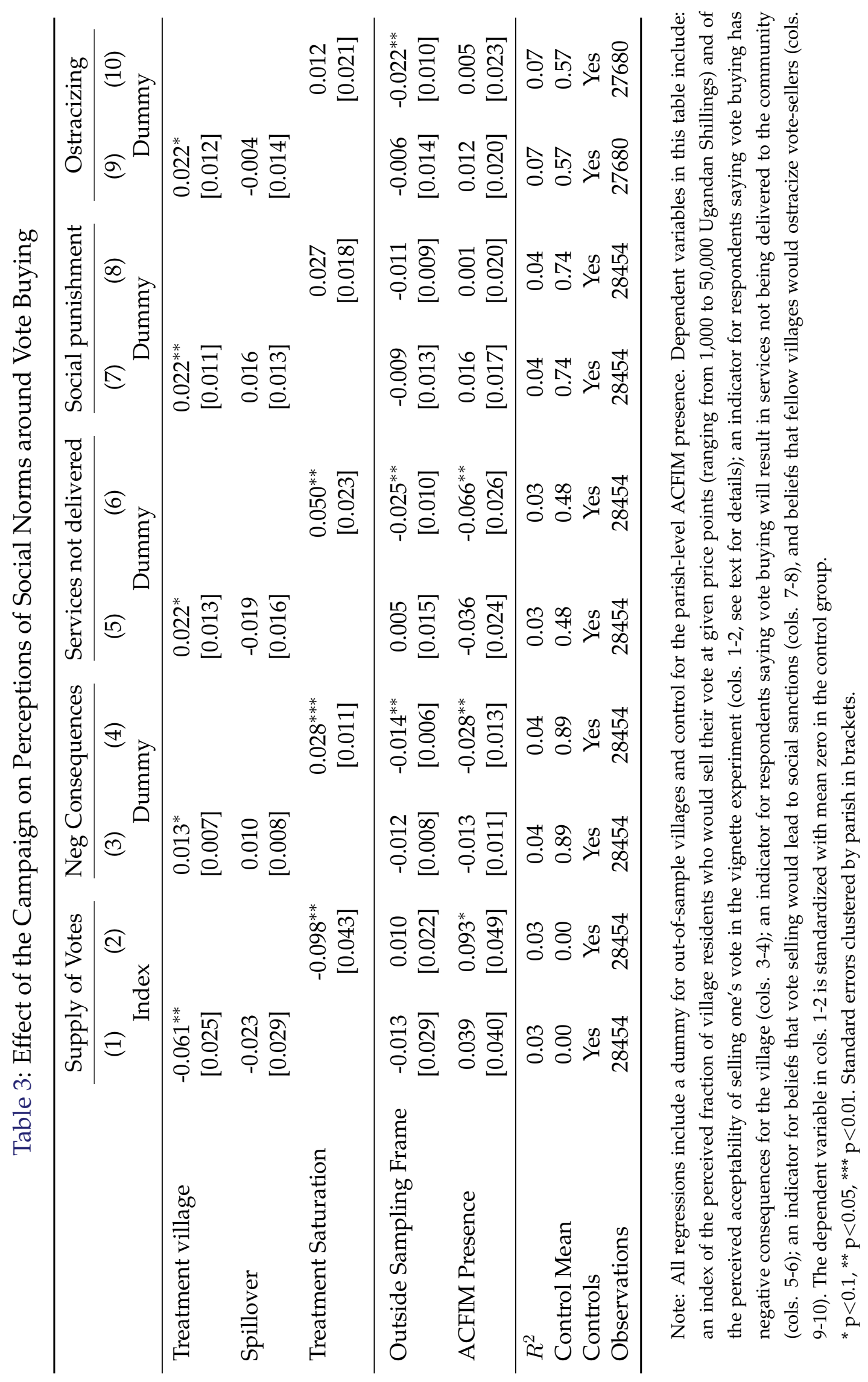


As anticipated in Section 6.2, in columns 1-2 of Table 4, we do not see any evidence of a change in vote buying when pooling all races and candidates. Reports of vote-buying transactions increase by just 0.039 standard deviations in treated villages. The confidence intervals rule out increases of 0.1 standard deviations or greater. These results, however, mask substantial heterogeneity across candidates. While there are no significant treatment or spillover effects on vote buying by incumbents, we observe significantly positive effects for challengers. Reports of vote-buying transactions by challengers significantly increase by 0.062 and $0.048 \mathrm{sd}$ in treated and spillover villages, while fully treated parishes experience a significant $0.087 \mathrm{sd}$ increase in reports of vote buying.

Heterogeneity. To further explore heterogeneity across candidates and to better comprehend the magnitudes of estimates in Table 4, Tables A9 and A10 assess the effect of the ACFIM campaign on the two main components of the index: an indicator of whether the respondent reported being offered cash, and the log amount of cash (plus 1 UGX) offered. ${ }^{33}$ The results are very similar to those in Table 4 . Worth noting, however, is the magnitude of the effects on challengers. Challengers offered cash in exchange for votes to $31 \%$ more voters and spent $21 \%$ more in fully treated parishes than in control parishes.

Also noticeable is that the significant effect of the campaign on vote buying by challengers is similar in treatment and spillover villages. This is consistent with accounts by brokers working for challenger candidates. Some of these brokers reported starting to operate in treated villages where they previously did not operate, and possibly due to logistical returns to scale in campaigning, also moved to spillover villages in treated parishes. These figures and accounts then suggest that a significant amount of the increase in vote buying by challengers took place along the extensive margin, i.e., vote buying in villages and parishes where they previously did not operate. To explore this, Table A11 follows the same baseline specifications and considers as outcomes indicators whether candidates and their brokers bought votes in a village. These estimates sum across the presidential and MP races, so that the outcome variables are counts of candidates. ${ }^{34}$ Results indeed suggest that challenger candidates and their brokers, but not incumbents and their operatives, were more likely to start working in villages where they previously did not operate. While these are noisier estimates (sometimes falling short of conventional levels of significance), we observe that, relative to control villages and parishes, in treated and spillover villages and fully treated parishes respectively there is an $8 \%, 16 \%$, and $16 \%$ extensive-margin increase in vote buying.

Reciprocity. Table 5 examines whether vote-selling behavior in villages exposed to the campaign is consistent with a weakening of reciprocity. While Table 4 makes clear that the campaign did not reduce the extent to which voters accepted gifts from politicians, it may have encouraged some voters to accept gifts from several politicians, and/or to vote for their preferred candidate regardless of gifts received. In columns 1-2 of Table 5, we look at treatment effects on a (standardized) indicator that voters received cash from both incumbents and challengers running in the same electoral race (presidential or parliamentary). The campaign led to a $0.038 \mathrm{sd}$ increase in treated villages in gifts received from

from a particular candidate if she mentioned this candidate among the individuals the brokers were working for.

${ }^{33} \mathrm{We}$ do not condition on being offered a positive amount of money in these estimates, so they should not be interpreted as price effects, but rather as effects on the average amount offered (including both the intensive and extensive margins).

${ }^{34}$ Note that there can be at most two incumbents (one president and one MP), but many more potential challengers. 
Table 4: Effects of the Campaign on Vote Buying (Cash or Goods)

\begin{tabular}{|c|c|c|c|c|c|c|}
\hline & \multicolumn{2}{|c|}{$\begin{array}{c}\text { Vote buying } \\
\text { by any candidate }\end{array}$} & \multicolumn{2}{|c|}{$\begin{array}{l}\text { Vote buying } \\
\text { by incumbents }\end{array}$} & \multicolumn{2}{|c|}{$\begin{array}{l}\text { Vote buying } \\
\text { by challengers }\end{array}$} \\
\hline & (1) & (2) & (3) & (4) & (5) & (6) \\
\hline & \multicolumn{2}{|c|}{ Index } & \multicolumn{2}{|c|}{ Index } & \multicolumn{2}{|c|}{ Index } \\
\hline Treatment village & $\begin{array}{c}0.039 \\
{[0.025]}\end{array}$ & & $\begin{array}{c}0.007 \\
{[0.026]}\end{array}$ & & $\begin{array}{c}0.062^{* * *} \\
{[0.024]}\end{array}$ & \\
\hline Spillover & $\begin{array}{c}0.018 \\
{[0.025]}\end{array}$ & & $\begin{array}{c}-0.010 \\
{[0.029]}\end{array}$ & & $\begin{array}{c}0.048^{*} \\
{[0.028]}\end{array}$ & \\
\hline Treatment Saturation & & $\begin{array}{c}0.063 \\
{[0.045]}\end{array}$ & & $\begin{array}{c}0.018 \\
{[0.047]}\end{array}$ & & $\begin{array}{l}0.087^{*} \\
{[0.045]}\end{array}$ \\
\hline Outside Sampling Frame & $\begin{array}{l}-0.010 \\
{[0.025]}\end{array}$ & $\begin{array}{l}-0.023 \\
{[0.018]}\end{array}$ & $\begin{array}{c}0.001 \\
{[0.028]}\end{array}$ & $\begin{array}{l}-0.012 \\
{[0.019]}\end{array}$ & $\begin{array}{l}-0.018 \\
{[0.028]}\end{array}$ & $\begin{array}{c}-0.023 \\
{[0.017]}\end{array}$ \\
\hline ACFIM Presence & $\begin{array}{l}-0.017 \\
{[0.044]}\end{array}$ & $\begin{array}{l}-0.051 \\
{[0.048]}\end{array}$ & $\begin{array}{l}-0.066 \\
{[0.049]}\end{array}$ & $\begin{array}{l}-0.077 \\
{[0.053]}\end{array}$ & $\begin{array}{c}0.066 \\
{[0.046]}\end{array}$ & $\begin{array}{c}0.020 \\
{[0.048]}\end{array}$ \\
\hline$R^{2}$ & 0.06 & 0.06 & 0.06 & 0.06 & 0.04 & 0.04 \\
\hline Con & Yes & Yes & Yes & Yes & Yes & Yes \\
\hline Observations & 28454 & 28454 & 28454 & 28454 & 28454 & 28454 \\
\hline
\end{tabular}

Note: All regressions include a dummy for out-of-sample villages and control for the parish-level ACFIM presence. The dependent variable is a standardized index of the following variables: any cash received, natural log of the amount of cash received, any gift received, and log of the value of any gift received, measured for any candidate running in the presidential and parliamentary races (cols. 1-2), or separately for incumbent candidates (cols. 3-4) and challenger candidates (cols. 5-6). All indices have mean zero in the control group.

${ }^{*} \mathrm{p}<0.1,{ }^{* *} \mathrm{p}<0.05,{ }^{* * *} \mathrm{p}<0.01$. Standard errors clustered by parish in brackets.

competing candidates (incumbents and challengers), as well as a 0.080 sd increase in fully saturated parishes, both of which fall just short of statistical significance at conventional levels. The campaign's effect on this outcome in spillover villages is close to zero and statistically insignificant. In columns 3-4, we look at an indicator for respondents reporting they accepted cash from a candidate but voted for a different candidate in a given electoral race. These reports significantly increase by 0.04 sd in treatment villages and by $0.027 \mathrm{sd}$ (statistically insignificant) in spillover villages. The effect of treatment saturation is $0.06 \mathrm{sd}$ but falls short of statistical significance. Overall, the results in Table 5 provide suggestive evidence that the campaign convinced some voters to "eat widely, and vote wisely" - namely to accept gifts from multiple candidates, without feeling compelled to vote for any given candidate on election day.

\subsection{Program impacts on campaigning activities}

We then explore the effect of the ACFIM campaign on standard campaigning tactics, which we a priori expected to be a natural substitute for vote buying. In Table 6, we examine an index of activities conducted 
Table 5: Vote Buying and Reciprocity

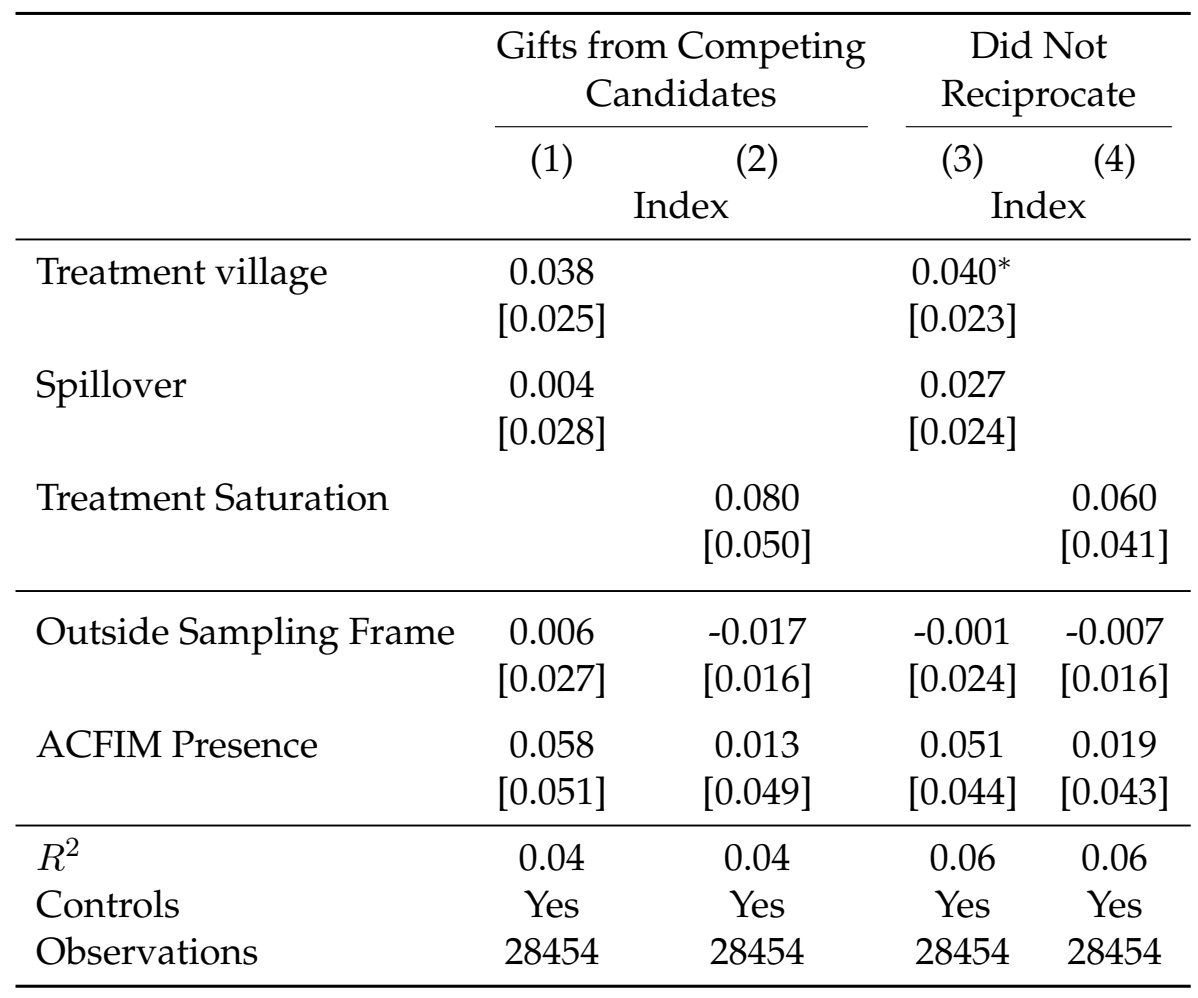

Note: All regressions include a dummy for out-of-sample villages and control for the parish-level ACFIM presence. The dependent variable in columns 1-2 is an indicator for respondents reporting they received cash from both incumbents and challengers running in the same electoral race (presidential or parliamentary, summing across both races). The dependent variable in columns 3-4 is an indicator for respondents reporting they accepted cash from a candidate but voted for a different candidate in a given race. All outcomes are standardized with mean zero in the control group.

${ }^{*} \mathrm{p}<0.1,{ }^{* *} \mathrm{p}<0.05,{ }^{* * *} \mathrm{p}<0.01$. Standard errors clustered by parish in brackets. 
by both types of candidates across presidential and parliamentary races. The activities most mentioned by voters were displaying political posters in the village, village visits by candidates, and campaigning through loudspeakers, SMS or phone calls. The outcome we examine in Table 6 is a standardized sum of activities conducted by candidates across the presidential and parliamentary races.

Results in columns 3-4 indicate that, for incumbent candidates, the campaign had a positive but insignificant effect in treatment villages and in highly saturated parishes. In contrast, challengers campaigned more actively in response to the ACFIM intervention. For instance, column 6 indicates a 0.168 sd increase in campaigning activities by challengers in fully treated parishes relative to control parishes. Finally, Table A24 reports treatment and spillover effects by parish saturation and suggests that the treatment effect of the ACFIM campaign is mainly driven by spillovers on the treated (as opposed to direct treatment effects of the intervention), consistent with the notion that this effect mostly took place along the extensive margin-challengers and their brokers entering parishes where they did not previously operate. Overall these estimates suggest that, contrary to our expectations, vote-buying and policycampaigning strategies are complements rather than substitutes. ${ }^{35}$ Together with the increase in vote buying by challenger candidates, this intensification of campaigning activities may be responsible for the increase in turnout in treated parishes documented in Table 2.

\section{Discussion}

Our results show that the ACFIM campaign had a meaningful effect on vote shares, social norms, as well as vote buying and campaigning tactics by candidates and their brokers. Challenger candidates attempted to buy more votes and campaigned more actively in villages exposed to the campaign, while incumbents did not respond in the same way. These results are largely driven by parishes with high treatment saturation, with little difference between the point estimates for treatment and spillover villages. Consequently, any theoretical explanation for these findings should account for effects of the campaign that permeate the entire treated parish, rather than solely treated villages within those parishes.

We believe that one of two complementary explanations can account for these results when focusing on the supply side of the market for votes-the voters. First, the campaign weakened the reciprocity norm around vote-buying arrangements, leading voters to no longer think of them as binding contracts. Instead, voters voted for the candidate they deemed better suited for office. This behavior is described by the Ugandan adage "Eat widely, vote wisely," which was adopted as the official resolution in more than $30 \%$ of villages that reached an official resolution. By convincing voters that they should be free to vote for their preferred candidate, as opposed to the highest-bidding candidate, the ACFIM campaign substantially reduced the advantage of incumbents, who generally have a stronger local presence and can afford more vote buying.

The second alternative is that the campaign served, inadvertently, to coordinate voters on an antiincumbent message. The framing of the campaign was about the pernicious effect of vote-buying practices on public service delivery. Moreover, both vote buying and poor service delivery are associated

\footnotetext{
${ }^{35}$ This is also supported by the positive correlation $(0.14)$ between the two variables in control parishes.
} 
Table 6: Effects on Campaigning Activities

\begin{tabular}{|c|c|c|c|c|c|c|}
\hline & \multicolumn{2}{|c|}{$\begin{array}{l}\text { Campaigning } \\
\text { by any candidate }\end{array}$} & \multicolumn{2}{|c|}{$\begin{array}{l}\text { Campaigning } \\
\text { by incumbents }\end{array}$} & \multicolumn{2}{|c|}{$\begin{array}{l}\text { Campaigning } \\
\text { by challengers }\end{array}$} \\
\hline & (1) & (2) & (3) & (4) & (5) & (6) \\
\hline & \multicolumn{2}{|c|}{ Index } & \multicolumn{2}{|c|}{ Index } & \multicolumn{2}{|c|}{ Index } \\
\hline Treatment village & $\begin{array}{c}0.050 \\
{[0.041]}\end{array}$ & & $\begin{array}{c}0.043 \\
{[0.040]}\end{array}$ & & $\begin{array}{c}0.047 \\
{[0.041]}\end{array}$ & \\
\hline Spillover & $\begin{array}{c}-0.036 \\
{[0.046]}\end{array}$ & & $\begin{array}{c}-0.020 \\
{[0.044]}\end{array}$ & & $\begin{array}{c}-0.043 \\
{[0.046]}\end{array}$ & \\
\hline Treatment Saturation & & $\begin{array}{c}0.149^{*} \\
{[0.079]}\end{array}$ & & $\begin{array}{c}0.093 \\
{[0.077]}\end{array}$ & & $\begin{array}{l}0.168^{* *} \\
{[0.080]}\end{array}$ \\
\hline Outside Sampling Frame & $\begin{array}{c}0.049 \\
{[0.038]}\end{array}$ & $\begin{array}{c}-0.018 \\
{[0.023]}\end{array}$ & $\begin{array}{c}0.038 \\
{[0.039]}\end{array}$ & $\begin{array}{l}-0.007 \\
{[0.024]}\end{array}$ & $\begin{array}{c}0.049 \\
{[0.037]}\end{array}$ & $\begin{array}{c}-0.023 \\
{[0.022]}\end{array}$ \\
\hline ACFIM Presence & $\begin{array}{l}-0.033 \\
{[0.079]}\end{array}$ & $\begin{array}{l}-0.120 \\
{[0.079]}\end{array}$ & $\begin{array}{l}-0.080 \\
{[0.076]}\end{array}$ & $\begin{array}{l}-0.135^{*} \\
{[0.076]}\end{array}$ & $\begin{array}{c}0.010 \\
{[0.079]}\end{array}$ & $\begin{array}{c}-0.088 \\
{[0.080]}\end{array}$ \\
\hline$R^{2}$ & 0.12 & 0.12 & 0.13 & 0.13 & 0.11 & 0.11 \\
\hline Con & Yes & Ye & $\mathrm{Ye}$ & Ye & Ye & Yes \\
\hline Observa & 28454 & 28454 & 28454 & 28454 & 28454 & 28454 \\
\hline
\end{tabular}

Note: All regressions include a dummy for out-of-sample villages and control for the parish-level ACFIM presence. The dependent variable is the standardized sum of indicators of campaigning activities: visit to the village, posters, leaflets, advertising over loudspeakers, and merchandise, measured for any candidate running in the presidential and parliamentary races (cols. 1-2), or separately for incumbent candidates (cols. 3-4) and challenger candidates (cols. 5-6). All outcomes are standardized indices with mean zero in the control group.

${ }^{*} \mathrm{p}<0.1,{ }^{* *} \mathrm{p}<0.05,{ }^{* * *} \mathrm{p}<0.01$. Standard errors clustered by parish in brackets. 
with incumbents. As a result, notwithstanding the neutral tone of the campaign with respect to incumbency status, the leaflet message and associated public meetings might have shifted beliefs and attitudes about incumbents in treated villages. Because we approached the evaluation of the ACFIM campaign with a theoretical framework along the lines of the first explanation in mind, our survey data does not allow us to assess the extent to which this second explanation complements it.

However, Table A20, which reports treatment and spillover effects by parish saturation, provides evidence at odds with this alternative explanation. In this table, the campaign's effects on the electoral performance of incumbents appears mainly driven by spillovers on the treated, as opposed to direct effects of the intervention. This suggests that electoral effects are likely driven both by a change in social norms (columns 2-3 of Table A21) and by a change in the campaigning tactics of candidates (Table A24), which exhibit a similar pattern of effects and together contributed to a breakdown in reciprocity. The fact that the campaign served as an anti-incumbent platform is unlikely to explain these effects, since if that were the case, we would observe a direct negative effect of the campaign on incumbent support. Instead, Table A20 shows the opposite: the TUT term in this table is actually positive (statistically insignificant).

Crucially, to account for the effects of the intervention, it is essential to understand the demand-side response to the ACFIM campaign-i.e., the response of candidates and their brokers. We observed a large increase in vote buying and campaigning by challenger candidates due to the expected weakening of reciprocity around vote-selling arrangements, which primarily hurt incumbents and leveled the electoral playing field. Importantly, this increase occurred throughout the treated parishes in both treated and spillover villages and is increasing with parish treatment saturation. We also provide anecdotal and quantitative evidence that these effects are driven by challengers starting to campaign in villages where they would have been deterred from operating absent the ACFIM campaign. These effects suggest that there are local returns to scale in vote buying and policy campaigning, possibly due to fixed costs of operating in an area, which our interviews with brokers corroborate.

Lastly, we rule out the possibility that several alternative explanations can fully account for these results. First, it is possible that the campaign did diminish vote buying, but, contrary to most expectations about the effect of social desirability bias, induced people to more honestly report vote buying in their villages, which yields a zero or positive effect on reported vote buying. This does not seem to be the case. For instance, we find no significant effect of the campaign on self-reported vote buying in the 2011 election, as we show in columns 1-2 of Table A25. Since the 2011 election pre-dated the campaign, there should be no relationship between treatment assignment and 2011 vote buying, except through a social desirability or salience channel. In addition, our results on norms about vote buying suggest that the campaign intensified negative feelings about vote buying.

Second, it is possible that the effects of the campaign on electoral results are due in part to agency problems between candidates and their brokers. Interviews with candidates and brokers indicate that the latter are subject to significant moral hazard and that, despite the efforts invested by candidates to monitor their brokers, these manage to extract significant rents. Candidates often offer brokers performance contracts wherein brokers receive lump sums of resources and are expected to deliver a certain level of electoral support to the candidates. Brokers who fail to reach these targets lose contingent re- 
wards in the form of keeping their position in future elections. Brokers then solve a cost-minimization problem to achieve their target and keep the remaining resources for themselves. If brokers working for incumbent candidates responded to the ACFIM campaign by giving up on the prospect of contingent rewards and reducing the fraction of the money allocated to voters, instead increasing what they kept for themselves, this would have contributed to the effects of the campaign on electoral outcomes. However, we do not observe a decrease in vote-buying offers or amounts by brokers working for incumbents. ${ }^{36}$ In addition, importantly, this alternative explanation does not account for the electoral effects of the campaign in spillover villages, which can only be explained by an increase in vote buying and policy campaigning by challenger candidates and their brokers.

Third, it is possible that the campaign deterred electoral fraud that otherwise would have favored the incumbents by engaging citizens in the electoral process. As highlighted by the results in Table A13, there is no evidence that the ACFIM campaign is associated (either positively or negatively) with the presence of markers for electoral irregularities.

\section{Conclusion}

This paper documents the effect of one of the largest anti-vote-buying campaigns ever evaluated-with almost half a million voters exposed across nearly 1,500 treated villages in Uganda-on electoral outcomes, vote buying, and campaigning tactics. We found that the campaign, in spite of its relatively heavy footprint-leaflets, three village meetings, and a village-wide resolution-was not effective at diminishing vote buying. Despite the campaign's inability to introduce a refusal norm, we provide evidence that it was successful at weakening the reciprocity norm associated with vote-buying transactions, and thus freed voters from reciprocal vote-buying relationships with incumbent candidates and their brokers. Anticipating these effects of the campaign on voter behavior, which they saw as leveling the playing field against incumbents, challenger candidates and their brokers intensified their vote-buying and campaigning efforts. As a result, the ACFIM campaign significantly hurt the electoral performance of incumbents while benefiting challengers. These effects are large, enough to reverse the relative electoral performance of the average incumbent and challenger in fully saturated parishes.

Our results on vote buying runs counter to previous experimental evidence on such campaigns, as in Hicken et al. (2017), Vicente (2014), and Vasudevan (2018), who find sizable negative impacts on votes sold. The differences between our findings and those of Hicken et al. (2017) and Vicente (2014) are likely explained by the difference in scope between the ACFIM campaign and the interventions they evaluate. The large scale and high degree of publicity of the ACFIM campaign, as well as the fact that local brokers attended the community meetings intended to coordinate citizens' efforts against vote buying, prompted candidates to respond to the campaign. In addition, the commonly held resolution to "eat widely, vote wisely" meant that the effects may have shifted away from changes in vote-buying levels and towards changes in voting decisions conditional on the vote-buying offer they accepted. In

\footnotetext{
${ }^{36}$ Nor do we observe a bimodal distribution of vote-buying offers, where some brokers give up and others redouble their efforts, which could also occur.
} 
contrast to Vasudevan (2018), whose mass mode of delivery and proximity to the election prevented candidates from responding strategically by reallocating resources across localities, our evaluation was crafted to measure such a response.

Importantly, our results indicate that it may be possible to disrupt the effectiveness of vote buying by weakening its relationship with voter behavior. In a dynamic game, where candidates seek to use the most cost-effective methods of gaining voter support, this weakening in voter willingness to honor the vote-buying "contract" should induce candidates to shift towards other methods of persuasion in future elections. Thus, we might expect this result to change candidate behavior. In particular, these results may induce candidates to emphasize and keep promises of future public goods rather than vote buying, which could have substantial impacts on governance in Uganda. Future research should continue to examine this aspect of candidates' strategy optimization and its implications for electoral and economic outcomes.

In terms of welfare, as with any intervention around elections, the effects are difficult to estimate and a full accounting is beyond the scope of this paper. On the one hand, increased vote buying by challenger candidates might lead to associated corruption and undermine their provision of public services, if elected to office. On the other hand, previous research (e.g., Besley et al. (2010)) suggests that increasing the competitiveness of local elections improves the quality of governance. In this sense, since the campaign appeared to have leveled the electoral playing field, we might expect it to have positive effects on public service delivery, even if the identity of those elected to office was not affected by the ACFIM campaign. Also note that, since the total amount of cash and goods received by voters did not fall, voters had no short-term costs in foregone vote-buying offers.

Future work should also continue to explore how to break down the vote-buying equilibrium. Our results highlight that one-sided interventions of large scale and visibility are likely to fail to eradicate vote buying if candidates respond to them. Future work would ideally then target both candidates and voters for treatment. In particular, in addition to tackling vote selling, as we did in our intervention, there is the need to convince candidates to credibly pledge not to buy votes, which would undermine the demand for vote buying. These efforts are politically sensitive and thus would need to be taken by a local organization with strong connections to multiple political parties, but could yield important insights about the relative merits of intervening on the demand side, as opposed to simply the supply side, of the votes' market.

This paper then opens new avenues of research on both on vote buying and policy campaigning in developing countries more broadly. This remains a fruitful area for more work, with important policy implications and potential for contributions to our knowledge about candidate, broker and voter behavior and governance. 


\section{References}

Agence France Presse, "Ugandan election commission lacks "independence": EU observers," Daily Mail, 20 February 2016. 2016.

Amnesty International, “Amnesty International International Report 2015/2016," Technical Report 2016.

Associated Press, "Ugandans cast votes in presidential elections after lengthy delays," The Guardian, 28 February 2016. 2016.

Baird, Sarah, J. Aislinn Bohren, Craig McIntosh, and Berk Özler, “Optimal Design of Experiments in the Presence of Interference," Review of Economics and Statistics, 2018, 100 (5), 844-860.

Beaman, Lori, Raghabendra Chattopadhyay, Esther Duflo, Rohini Pande, and Petia Topalova, "Powerful Women: Does Exposure Reduce Bias?," Quarterly Journal of Economics, 2009, 124 (4), 1497-1540.

Beber, Bernd and Alexandra Scacco, "What the Numbers Say: A Digit-Based Test for Election Fraud," Political Analysis, 2012, 20 (2), 235-247.

Berman, Eli, Michael Callen, Clark Gibson, and James D. Long, "Election Fairness and Government Legitimacy in Afghanistan," NBER Working Paper No. 19949, 2014.

Besley, Timothy, Torsten Persson, and Daniel M. Sturm, "Political Competition, Policy and Growth: Theory and Evidence from the US," Review of Economic Studies, 2010, 77, 1329-1352.

Bidwell, Kelly, Katherine Casey, and Rachel Glennerster, "Debates: Voting and Expenditure Responses to Political Communication," forthcoming Journal of Political Economy, 2019.

Bobonis, Gustavo, Paul Gertler, Marco Gonzalez-Navarro, and Simeon Nichter, "Vulnerability and Clientelism," NBER Working paper No. 23589, 2017.

Bowles, Jeremy and Horacio Larreguy, "Who Debates, Who Wins? At-Scale Experimental Evidence on Debate Participation in a Liberian Election," 2018.

Conroy-Krutz, Jeff, "What Determines the Price of a Vote? Motive, Means, and Opportunity in VoteBuying Practices," 2012.

Cruz, Cesi, Julien Labonne, and Pablo Querubin, "Politician Family Networks and Electoral Outcomes: Evidence from the Philippines," American Economic Review, 2017, 107, 3006-3037.

Democracy Monitoring Group, "Report on Money in Politics: Pervasive Vote Buying in Ugandan Elections," Technical Report January 2011.

European Union Election Observation Mission, “Uganda, Presidential, Parliamentary and Local Council Elections," Technical Report 2016. 
Finan, Frederico and Laura Schechter, "Vote-Buying and Reciprocity," Econometrica, 2012, 80 (2), $863-$ 881.

Frey, Anderson, "Strategic Allocation of Anti-Clientelism Goods and the Breaking of Political Machines," Working Paper, 2019.

Fujiwara, Thomas and Leonard Wantchekon, "Can Informed Public Deliberation Overcome Clientelism? Experimental Evidence from Benin," American Economic Journal: Applied Economics, 2013, 5 (4), 241-255.

Gaffey, Conor, “Uganda 2016: Mbabazi mounts challenge to election results,” Newsweek, 2 March 2016. 2016.

Gerber, Alan S. and Donald P. Green, "Field Experiments and Voter Mobilization: An Overview of a Burgeoning Literature," in Abhijit V. Banerjee and Esther Duflo, eds., Handbook of Field Experiments, 2017, pp. 395-438.

Hicken, Allen, "Clientelism," Annual Review of Political Science, 2011, 14, 289-310.

_ , Stephen Leider, Nico Ravanilla, and Dean Yang, “Temptation in Vote-Selling: Evidence from a Field Experiment in the Philippines," Journal of Development Economics, 2017, 131, 1-14.

Khemani, Stuti, "Buying votes versus supplying public services: Political incentives to under-invest in pro-poor policies," Journal of Development Economics, 2015, 117, 84-93.

Kling, Jeffrey R., Jeffrey B. Liebman, and Lawrence F. Katz, "Experimental Analysis of Neighborhood Effects," Econometrica, 2007, 75 (1), 83-119.

Larreguy, Horacio, John Marshall, and Laura Trucco, "Breaking Clientelism or Rewarding Incumbents? Evidence from an Urban Titling Program in Mexico," Working Paper, 2018.

Muralidharan, Karthik and Paul Niehaus, "Experimentation at Scale," Journal of Economic Perspectives, 2017, 31 (4), 103-124.

Nichter, Simeon, "Vote Buying or Turnout Buying? Machine Politics and the Secret Ballot," American Political Science Review, 2008, 102 (1), 19-31.

Robinson, James A. and Thierry Verdier, "The Political Economy of Clientelism.," Scandinavian Journal of Economics, 2013, 115(2), 260-291.

Stokes, Susan C., "Perverse accountability: A formal model of machine politics with evidence from Argentina," American Political Science Review, 2005, 99 (3), 315-325.

Tripp, Aili Mari, Museveni's Uganda: Paradoxes of Power in a Hybrid Regime, Boulder, CO: Lynne Rienner Publishers, 2010. 
Vasudevan, Srinivasan, "Diminishing the Effectiveness of Vote Buying: Experimental Evidence from a Persuasive Radio Campaign in India," Working paper, 2018.

Vicente, Pedro C., "Is Vote Buying Effective? Evidence from a Field Experiment in West Africa," Economic Journal, 2014, 124, F356-F387.

- and Leonard Wantchekon, "Clientelism and vote buying: lessons from field experiments in African elections," 2009, 25 (2), 292-305. 


\section{A Appendix (For Online Publication)}

\section{A.1 Variables used for Randomization Checks}

We present randomization checks in Appendix Tables A2 through A7. From the voter survey, we use the age, years of education, marital status (an indicator variable for married individuals), land ownership (an indicator for households that own any land), the number of adults and children in the household, an index of asset ownership, ${ }^{37,38}$ variables indicating the individual belongs to one of Uganda's three largest ethnic groups (Ganda, Nkole and Soga), and three indicator variables for being a Catholic, a Protestant, or a Muslim.

From the key informant survey, we use the years of education and marital status of the respondent, as well as the same four measures of occupational status, ethnicity and religion as above (note that age, land ownership, number of members in the household and assets were not collected in the key informant survey), as well as four indicator variables for whether the key informant is a local chief or elder, a member of a civil society group (a religious, youth, or women's group), a village committee member or a local council member.

Finally, from the official electoral data we use the number of registered voters in 2011, the voter turnout in 2011, the presidential vote shares of the NRM and of the FDC in 2011, the vote share of the winner of the parliamentary vote in 2011 (i.e., the 2011 vote share of the 2016 incumbent MP), and the number of registered voters in 2016.

\section{A.2 Electoral data integrity}

Opposition leaders in Uganda and international observers challenged the integrity of the voting data in the aftermath of the election (Agence France Presse, 2016; Gaffey, 2016). Analysts noted several potentially suspicious patterns. We acknowledge these issues, but believe that the electoral data can still be useful for our analysis for several reasons. First, we generally obtain similar results using self-reported voting outcomes from our voter survey and using the official election data.

Second, we show that our treatment is uncorrelated with traditional markers of electoral malfeasance (Beber and Scacco, 2012). Specifically, Table A12 indicates that treatment and spillover assignment, and parish saturation are uncorrelated with the last digit of the polling station valid votes and votes in favor of incumbents being rounded off to zero or to 5, which is usually associated with electoral fraud (Beber and Scacco, 2012). Only 1 out of 24 coefficients in this table is significant at $10 \%$. Note that the mean of the dependent variable in columns 5, 6, 13 and 14 highlight an abnormal share of polling stations with valid votes and votes in favor of incumbents rounded off to zero for the parliamentary vote. However, this rounding pattern is uncorrelated with treatment and spillover assignment or saturation, which confirms

\footnotetext{
${ }^{37}$ To construct this index, we simply add up the variables indicating ownership of a TV, radio, motor vehicle, and cell phone four measures of occupational status (indicator variables for individuals working in farming, trade/retail, any high-skill activity, or not actively working)

${ }^{38}$ High-skill individuals include artisans or skilled manual workers, clerks and secretaries, supervisors, managers, security providers, mid-level professionals such as teachers, and upper-level professionals. Individuals not actively working include students as well as unemployed, retired, and disabled individuals.
} 
the validity of our estimates using the official election data.

Furthermore, in Table A13, we show that treatment assignment and saturation do not significantly correlate with "suspicious polling stations," defined by being either at least 2 standard deviations above the sample average in both turnout and support for the incumbent president, the incumbent MP, or both. Overall, there is no evidence that treatment and spillover assignment or parish saturation correlate with electoral malfeasance.

\section{A.3 Results from Pre-Specified Hypotheses}

We report treatment effects on the main hypotheses of our pre-analysis plan in Appendix Tables A14 through Table A18. All tables report estimates from four specifications: equation (1) in column 1, equation (2) in column 2, a modified version of equation (3) in column 3 that includes interactions between ACFIM presence and the Treatment and Spillover dummies, and equation (3) in column 4 . The specification used in column 3 is the original version of equation (3) that we included in our pre-analysis plan, but the correct specification should not include these interactions since they capture some of the treatment effects of interest.

Our primary hypotheses stated that vote buying should fall in treatment villages (Hypothesis 1) and rise in spillover villages (Hypothesis 2). We expected the intensity of these effects to be increasing in parish saturation levels (Hypotheses 7 and 8). To test for these hypotheses, the outcome in Table A14 is a preregistered index of self-reported vote buying, knowledge of particular individuals who sold their vote, and perceptions of the frequency of vote buying in the village from the voter survey and the key informant survey. Even if the main coefficients of interest in column 1 have the expected sign, we find little evidence in support of these hypotheses: the main effects of treatment and spillover are statistically insignificant and small in magnitude (column 1, Hypotheses 1 and 2). There is also little evidence that treatment effects vary with saturation levels (column 4, Hypotheses 7 and 8).

In Table A15, we show treatment effects for our Hypothesis 3A: the supply of votes (i.e., the perceived willingness to sell one's vote) should fall in treatment villages. The dependent variable for this hypothesis is an index of the perceived fraction of village residents who would sell their vote at given price points (ranging from 1,000 to 50,000 UShs) and of the perceived acceptability of selling one's vote in the vignette experiment (as in columns 9-10 in Table 3 in the main text). We find that the (perceived) supply of votes fell in treatment villages (see column 1) and in highly saturated parishes (column 2).

Table A16 shows results for our Hypothesis 3B: demand for votes may rise or fall in treatment villages. The dependent variable is an index of total offers received from brokers (accepted or rejected) and of the perceived fraction of village residents who were given a vote-buying offer. Overall, we do not find significant treatment effects supporting this hypothesis, though both the coefficient on saturation (column 2) and the coefficient on the interaction of treatment with saturation (column 4) are positive. This table also provides a test of Hypothesis 5 (demand for votes increases in spillover villages): we find a positive, but statistically insignificant effect on the spillover variable (column 1 ) and on the interaction between spillover and saturation (column 4). These findings are in line with those in Figure 2 in the main text, but that masks heterogeneity across candidates shown in Table 4 also in the main text. 
Finally, Hypotheses 4 and 6 focused on the price of votes, which we argued may increase or decrease in treatment villages depending on the relative magnitude of demand and supply shocks (Hypothesis 4), and increase in spillover villages (Hypothesis 6). Tables A17 and A18 present results from these tests, using the two different outcomes we pre-specified: a measure of the total amount of cash and goods received by the voter from all brokers in Table A17, and an index of typical amounts offered by candidates from the key informant survey in Table A18. The results from these tables are inconclusive: treatment and spillover effects are positive and statistically insignificant in Table A17, and negative and statistically insignificant in Table A18.

\section{A.4 Discussion of external validity}

The presence of a local ACFIM activist is clearly non-random. Our treatment randomization was within the sample of parishes/villages with local ACFIM activists, so this is not a problem for internal validity, but it does require a brief discussion on external validity. From the perspective of civil society organizations (CSOs) considering similar campaigns, the villages/parishes with pre-existing civil society presence may, in fact, be the policy-relevant sample. The strength of CSOs often lies in their local credibility, built over multiple years and sustained through the presence of local members of the larger national CSO. As a result, very few CSOs are willing to launch a campaign in locations where they had never worked before. In particular, this was our experience when we inquire with ACFIM about the possibility of extending the campaign to villages without ACFIM activists. However, it is still worth noting the differences.

First, to be in our sample, a parish must contain at least 1 village where a local ACFIM activist works or lives. Since we do not survey any parishes with zero ACFIM presence, we cannot compare our sample directly to other parishes. However, we can correlate the degree of ACFIM presence (i.e. the percent of voters in a given parish who live in villages with ACFIM presence) with covariates to explore this selection indirectly. For example, as expected, ACFIM presence is correlated with lower vote-share in 2011 for the incumbent president — in a parish with 100\% ACFIM presence the incumbent president got 7 percentage points fewer, on average, than in one with $\%$ ACFIM presence. Similarly, as expected, ACFIM presence is correlated with less prior vote buying: using the same $100 \%$ to $0 \%$ comparison, full

ACFIM presence is correlated with a 5 percentage lower share of respondents reporting receiving a gift for their voters in 2011.

Second, within each parish, we sample every village where an ACFIM activist had the potential to work. However, in addition, we sampled 1,399 additional villages in the eligible parishes that were ineligible for treatment, but could be affected by spillovers. Throughout the analysis, we control for an indicator that a village was not part of the experimental sampling frame. As can be seen in the results later, this dummy is usually insignificant, indicating that these villages do not generally differ from the untreated villages that were part of the experimental sample, though in some specifications a small difference appears. 
Table A1: Summary Statistics

\begin{tabular}{|c|c|c|c|}
\hline & Mean & SD & $N$ \\
\hline \multicolumn{4}{|l|}{ Survey Data } \\
\hline Recalls NGO visit in village & .324 & .468 & 27807 \\
\hline Received a leaflet & .172 & .377 & 28060 \\
\hline Recalls meetings took place & .129 & .335 & 27755 \\
\hline Attended meeting & .207 & .651 & 27745 \\
\hline Received a robo-call & .053 & .224 & 28507 \\
\hline Recalls posters & .129 & .335 & 28133 \\
\hline Negative consequences & .895 & .306 & 28507 \\
\hline People angry & .756 & .43 & 28507 \\
\hline Vote sellers ostracized & .579 & .494 & 27732 \\
\hline Vote-buying unacceptable & .744 & .437 & 28501 \\
\hline Any cash received, any candidate & .4 & .49 & 28507 \\
\hline Any cash - Incumbents & .331 & .578 & 28507 \\
\hline Any cash - Challengers & .111 & .321 & 28507 \\
\hline Cash amount received (USh) & 1526.1 & 4269.3 & 28507 \\
\hline Cash amount - incumbents & 1004.0 & 2864.7 & 28507 \\
\hline Cash amount - challengers & 697.8 & 2668.5 & 28507 \\
\hline Reported vote for incumbent & .658 & .349 & 27112 \\
\hline Campaign activities, all & 5.901 & 4.246 & 28507 \\
\hline Campaign activities, incumbents & 3.504 & 2.536 & 28507 \\
\hline Campaign activities, challengers & 2.397 & 2.25 & 28507 \\
\hline \multicolumn{4}{|l|}{ Electoral Data } \\
\hline Registered Voters & 574.0 & 202.9 & 3659 \\
\hline Turnout 2016, presidential ballot & .675 & .09 & 3659 \\
\hline Turnout 2016, parliamentary election & 689 & .086 & 3112 \\
\hline Incumbent vote share 2016 (pres.) & .614 & .184 & 3654 \\
\hline Challengers vote 2016 (pres.) & .386 & .184 & 3654 \\
\hline Incumbent vote share 2016 (parl.) & .441 & .246 & 3104 \\
\hline Challengers vote share 2016 (parl.) & .559 & .246 & 3104 \\
\hline Turnout 2011 (pres.) & .601 & .103 & 3641 \\
\hline Incumbent vote share 2011 (pres.) & .678 & .186 & 3641 \\
\hline
\end{tabular}


Table A2: Balance on Voter Respondent's Characteristics

\begin{tabular}{|c|c|c|c|c|c|c|c|c|c|c|c|c|}
\hline & \multicolumn{2}{|c|}{ Age } & \multicolumn{2}{|c|}{ Years Education } & \multicolumn{2}{|c|}{ Married } & \multicolumn{2}{|c|}{ Own Land } & \multicolumn{2}{|c|}{ Adults } & \multicolumn{2}{|c|}{ Children } \\
\hline & (1) & (2) & (3) & (4) & (5) & (6) & (7) & $(8)$ & (9) & $(10)$ & (11) & (12) \\
\hline Treatment village & $\begin{array}{c}-0.247 \\
{[0.302]}\end{array}$ & & $\begin{array}{c}0.012 \\
{[0.117]}\end{array}$ & & $\begin{array}{c}-0.011 \\
{[0.010]}\end{array}$ & & $\begin{array}{c}-0.002 \\
{[0.010]}\end{array}$ & & $\begin{array}{c}-0.014 \\
{[0.049]}\end{array}$ & & $\begin{array}{c}-0.078 \\
{[0.068]}\end{array}$ & \\
\hline Spillover & $\begin{array}{c}0.123 \\
{[0.338]}\end{array}$ & & $\begin{array}{c}-0.120 \\
{[0.146]}\end{array}$ & & $\begin{array}{c}-0.006 \\
{[0.011]}\end{array}$ & & $\begin{array}{c}0.002 \\
{[0.011]}\end{array}$ & & $\begin{array}{c}-0.044 \\
{[0.057]}\end{array}$ & & $\begin{array}{c}-0.223^{* * *} \\
{[0.075]}\end{array}$ & \\
\hline Treatment Saturation & & $\begin{array}{c}-0.079 \\
{[0.494]}\end{array}$ & & $\begin{array}{c}-0.004 \\
{[0.213]}\end{array}$ & & $\begin{array}{c}-0.011 \\
{[0.018]}\end{array}$ & & $\begin{array}{c}0.008 \\
{[0.020]}\end{array}$ & & $\begin{array}{c}-0.038 \\
{[0.090]}\end{array}$ & & $\begin{array}{c}-0.197 \\
{[0.130]}\end{array}$ \\
\hline Outside Sampling Frame & $\begin{array}{c}-0.843^{* *} \\
{[0.342]}\end{array}$ & $\begin{array}{c}-0.650^{* * *} \\
{[0.245]}\end{array}$ & $\begin{array}{c}0.170 \\
{[0.139]}\end{array}$ & $\begin{array}{c}0.083 \\
{[0.097]}\end{array}$ & $\begin{array}{c}-0.014 \\
{[0.011]}\end{array}$ & $\begin{array}{c}-0.012 \\
{[0.008]}\end{array}$ & $\begin{array}{c}-0.001 \\
{[0.010]}\end{array}$ & $\begin{array}{c}0.001 \\
{[0.007]}\end{array}$ & $\begin{array}{c}0.011 \\
{[0.051]}\end{array}$ & $\begin{array}{c}-0.010 \\
{[0.033]}\end{array}$ & $\begin{array}{c}0.096 \\
{[0.067]}\end{array}$ & $\begin{array}{c}-0.009 \\
{[0.045]}\end{array}$ \\
\hline ACFIM Presence & $\begin{array}{c}-1.085^{* *} \\
{[0.467]}\end{array}$ & $\begin{array}{c}-1.062^{* *} \\
{[0.518]}\end{array}$ & $\begin{array}{c}-0.176 \\
{[0.209]}\end{array}$ & $\begin{array}{c}-0.185 \\
{[0.223]}\end{array}$ & $\begin{array}{c}-0.022 \\
{[0.016]}\end{array}$ & $\begin{array}{c}-0.018 \\
{[0.018]}\end{array}$ & $\begin{array}{c}-0.044^{* * *} \\
{[0.017]}\end{array}$ & $\begin{array}{c}-0.048^{* *} \\
{[0.020]}\end{array}$ & $\begin{array}{c}0.354^{* * *} \\
{[0.082]}\end{array}$ & $\begin{array}{c}0.368^{* * *} \\
{[0.096]}\end{array}$ & $\begin{array}{c}0.696^{* * *} \\
{[0.114]}\end{array}$ & $\begin{array}{c}0.768^{* * *} \\
{[0.138]}\end{array}$ \\
\hline$R^{2}$ & 0.00 & 0.00 & 0.00 & 0.00 & 0.00 & 0.00 & 0.00 & 0.00 & 0.00 & 0.00 & 0.01 & 0.01 \\
\hline Control Mean & 40.088 & 40.088 & 5.487 & 5.487 & 0.741 & 0.741 & 0.872 & 0.872 & 3.181 & 3.181 & 3.551 & 3.551 \\
\hline Observations & 27375 & 27375 & 28452 & 28452 & 28454 & 28454 & 28454 & 28454 & 28454 & 28454 & 28451 & 28451 \\
\hline
\end{tabular}

Note: Odd-numbered columns report estimates from equation (1) and even-numbered columns report estimates from equation (2). All dependent variables come from the voter survey data (see text for details).

${ }^{*} \mathrm{p}<0.1,{ }^{* *} \mathrm{p}<0.05,{ }^{* * *} \mathrm{p}<0.01$. Standard errors clustered by parish in brackets. 
Table A3: Balance on Voter Respondent's Characteristics (Continues)

\begin{tabular}{|c|c|c|c|c|c|c|c|c|c|c|}
\hline & \multicolumn{2}{|c|}{ Assets } & \multicolumn{2}{|c|}{ Farmer } & \multicolumn{2}{|c|}{ Trade } & \multicolumn{2}{|c|}{ High Skill } & \multicolumn{2}{|c|}{ Not Working } \\
\hline & (1) & (2) & (3) & (4) & (5) & (6) & (7) & (8) & (9) & (10) \\
\hline Treatment village & $\begin{array}{c}-0.012 \\
{[0.032]}\end{array}$ & & $\begin{array}{c}0.025 \\
{[0.016]}\end{array}$ & & $\begin{array}{c}-0.008 \\
{[0.008]}\end{array}$ & & $\begin{array}{c}-0.005 \\
{[0.006]}\end{array}$ & & $\begin{array}{c}-0.008 \\
{[0.005]}\end{array}$ & \\
\hline Spillover & $\begin{array}{c}0.011 \\
{[0.038]}\end{array}$ & & $\begin{array}{c}0.015 \\
{[0.021]}\end{array}$ & & $\begin{array}{c}-0.006 \\
{[0.009]}\end{array}$ & & $\begin{array}{c}-0.011 \\
{[0.008]}\end{array}$ & & $\begin{array}{c}-0.002 \\
{[0.007]}\end{array}$ & \\
\hline Treatment Saturation & & $\begin{array}{c}-0.030 \\
{[0.059]}\end{array}$ & & $\begin{array}{c}0.028 \\
{[0.033]}\end{array}$ & & $\begin{array}{c}-0.012 \\
{[0.014]}\end{array}$ & & $\begin{array}{c}-0.008 \\
{[0.012]}\end{array}$ & & $\begin{array}{c}-0.009 \\
{[0.009]}\end{array}$ \\
\hline Outside Sampling Frame & $\begin{array}{c}-0.020 \\
{[0.033]}\end{array}$ & $\begin{array}{c}-0.004 \\
{[0.022]}\end{array}$ & $\begin{array}{c}-0.015 \\
{[0.017]}\end{array}$ & $\begin{array}{c}-0.018^{*} \\
{[0.010]}\end{array}$ & $\begin{array}{c}-0.006 \\
{[0.008]}\end{array}$ & $\begin{array}{c}-0.006 \\
{[0.005]}\end{array}$ & $\begin{array}{c}0.013 \\
{[0.008]}\end{array}$ & $\begin{array}{c}0.008 \\
{[0.005]}\end{array}$ & $\begin{array}{c}0.000 \\
{[0.006]}\end{array}$ & $\begin{array}{c}0.003 \\
{[0.004]}\end{array}$ \\
\hline ACFIM Presence & $\begin{array}{c}-0.186^{* * *} \\
{[0.055]}\end{array}$ & $\begin{array}{c}-0.170^{* * *} \\
{[0.062]}\end{array}$ & $\begin{array}{c}0.026 \\
{[0.028]}\end{array}$ & $\begin{array}{c}0.016 \\
{[0.032]}\end{array}$ & $\begin{array}{c}-0.018 \\
{[0.012]}\end{array}$ & $\begin{array}{c}-0.013 \\
{[0.014]}\end{array}$ & $\begin{array}{c}0.012 \\
{[0.010]}\end{array}$ & $\begin{array}{c}0.015 \\
{[0.011]}\end{array}$ & $\begin{array}{c}0.010 \\
{[0.008]}\end{array}$ & $\begin{array}{c}0.014 \\
{[0.009]}\end{array}$ \\
\hline $\begin{array}{l}R^{2} \\
\text { Control Mean } \\
\text { Observations }\end{array}$ & $\begin{array}{c}0.00 \\
1.638 \\
28454\end{array}$ & $\begin{array}{c}0.00 \\
1.638 \\
28454\end{array}$ & $\begin{array}{c}0.00 \\
0.687 \\
28453\end{array}$ & $\begin{array}{c}0.00 \\
0.687 \\
28453\end{array}$ & $\begin{array}{c}0.00 \\
0.088 \\
28453\end{array}$ & $\begin{array}{c}0.00 \\
0.088 \\
28453\end{array}$ & $\begin{array}{c}0.00 \\
0.078 \\
28453\end{array}$ & $\begin{array}{c}0.00 \\
0.078 \\
28453\end{array}$ & $\begin{array}{c}0.00 \\
0.053 \\
28453\end{array}$ & $\begin{array}{c}0.00 \\
0.053 \\
28453\end{array}$ \\
\hline
\end{tabular}

Note: Odd-numbered columns report estimates from equation (1) and even-numbered columns report estimates from equation (2). All dependent variables come from the voter survey data (see text for details).

${ }^{*} \mathrm{p}<0.1,{ }^{* *} \mathrm{p}<0.05,{ }^{* * *} \mathrm{p}<0.01$. Standard errors clustered by parish in brackets. 
Table A4: Balance on Voter Respondent's Characteristics (Continues)

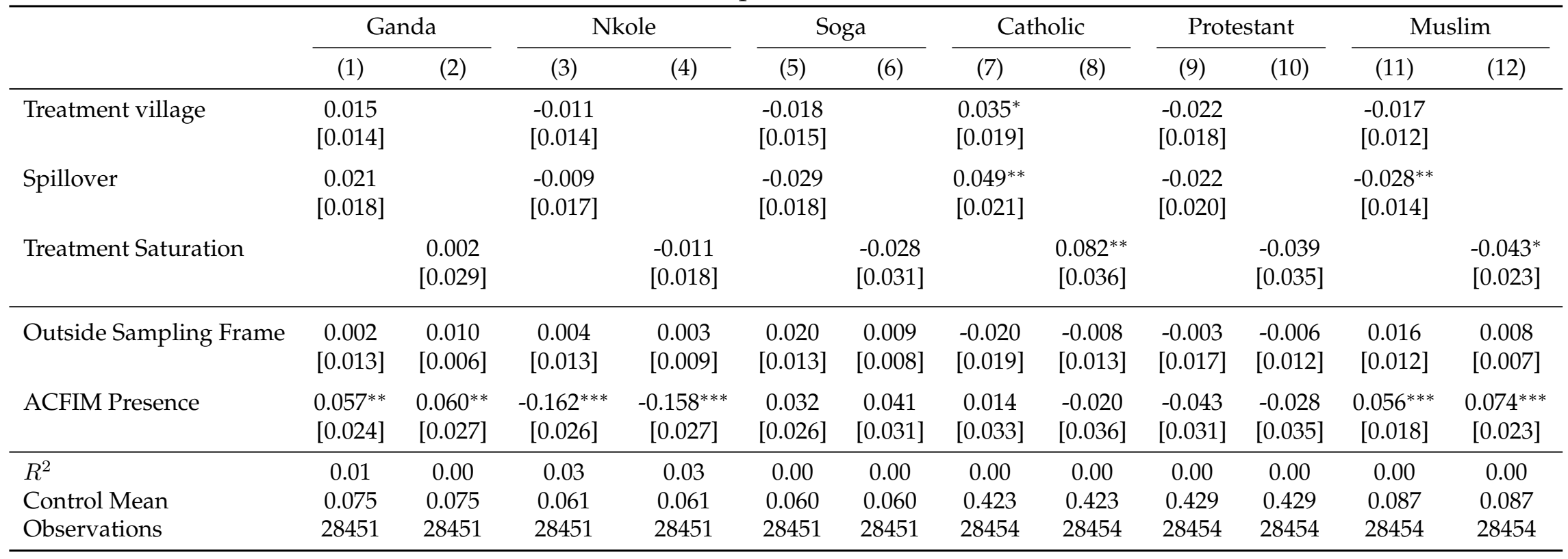

Note: Odd-numbered columns report estimates from equation (1) and even-numbered columns report estimates from equation (2). All dependent variables come from the voter survey data (see text for details).

${ }^{*} \mathrm{p}<0.1,{ }^{* *} \mathrm{p}<0.05,{ }^{* * *} \mathrm{p}<0.01$. Standard errors clustered by parish in brackets. 
Table A5: Balance on Key Informant Respondent's Characteristics

\begin{tabular}{|c|c|c|c|c|c|c|c|c|}
\hline & \multicolumn{2}{|c|}{ Chief or Elder } & \multicolumn{2}{|c|}{ Civil Society } & \multicolumn{2}{|c|}{ Village Committee } & \multicolumn{2}{|c|}{ Local Council } \\
\hline & (1) & (2) & (3) & (4) & (5) & (6) & (7) & (8) \\
\hline Treatment village & $\begin{array}{c}-0.019 \\
{[0.017]}\end{array}$ & & $\begin{array}{c}0.009 \\
{[0.008]}\end{array}$ & & $\begin{array}{c}-0.001 \\
{[0.026]}\end{array}$ & & $\begin{array}{c}0.026 \\
{[0.021]}\end{array}$ & \\
\hline Spillover & $\begin{array}{c}0.023 \\
{[0.023]}\end{array}$ & & $\begin{array}{l}-0.003 \\
{[0.008]}\end{array}$ & & $\begin{array}{c}-0.045 \\
{[0.031]}\end{array}$ & & $\begin{array}{c}0.012 \\
{[0.025]}\end{array}$ & \\
\hline Treatment Saturation & & $\begin{array}{c}-0.038 \\
{[0.031]}\end{array}$ & & $\begin{array}{c}0.014 \\
{[0.011]}\end{array}$ & & $\begin{array}{c}-0.015 \\
{[0.047]}\end{array}$ & & $\begin{array}{l}0.072^{*} \\
{[0.039]}\end{array}$ \\
\hline Outside Sampling Frame & $\begin{array}{l}-0.028 \\
{[0.021]}\end{array}$ & $\begin{array}{c}0.002 \\
{[0.013]}\end{array}$ & $\begin{array}{c}-0.002 \\
{[0.008]}\end{array}$ & $\begin{array}{l}-0.010 \\
{[0.007]}\end{array}$ & $\begin{array}{l}0.055^{* *} \\
{[0.027]}\end{array}$ & $\begin{array}{c}0.024 \\
{[0.016]}\end{array}$ & $\begin{array}{l}-0.005 \\
{[0.025]}\end{array}$ & $\begin{array}{l}-0.016 \\
{[0.016]}\end{array}$ \\
\hline ACFIM Presence & $\begin{array}{c}0.143^{* * *} \\
{[0.028]}\end{array}$ & $\begin{array}{c}0.166^{* * *} \\
{[0.035]}\end{array}$ & $\begin{array}{c}-0.028^{* *} \\
{[0.011]}\end{array}$ & $\begin{array}{c}-0.036^{* * *} \\
{[0.013]}\end{array}$ & $\begin{array}{c}-0.213^{* * *} \\
{[0.042]}\end{array}$ & $\begin{array}{c}-0.208^{* * *} \\
{[0.049]}\end{array}$ & $\begin{array}{c}0.152^{* * *} \\
{[0.034]}\end{array}$ & $\begin{array}{c}0.113^{* * *} \\
{[0.039]}\end{array}$ \\
\hline $\begin{array}{l}R^{2} \\
\text { Control Mean } \\
\text { Observations }\end{array}$ & $\begin{array}{c}0.01 \\
0.187 \\
4090\end{array}$ & $\begin{array}{c}0.01 \\
0.187 \\
4090\end{array}$ & $\begin{array}{c}0.00 \\
0.031 \\
4090\end{array}$ & $\begin{array}{c}0.00 \\
0.031 \\
4090\end{array}$ & $\begin{array}{c}0.02 \\
0.430 \\
4090\end{array}$ & $\begin{array}{c}0.02 \\
0.430 \\
4090\end{array}$ & $\begin{array}{c}0.01 \\
0.247 \\
4090\end{array}$ & $\begin{array}{c}0.01 \\
0.247 \\
4090\end{array}$ \\
\hline
\end{tabular}

Note: Odd-numbered columns report estimates from equation (1) and even-numbered columns report estimates from equation (2). All dependent variables come from the key informant survey data (see text for details).

${ }^{*} \mathrm{p}<0.1,{ }^{* *} \mathrm{p}<0.05,{ }^{* * *} \mathrm{p}<0.01$. Standard errors clustered by parish in brackets. 
Table A6: Balance on Key Informant Respondent's Characteristics (Continues)

\begin{tabular}{|c|c|c|c|c|c|c|c|c|c|c|c|c|}
\hline & \multicolumn{2}{|c|}{ Ganda } & \multicolumn{2}{|c|}{ Nkole } & \multicolumn{2}{|c|}{ Soga } & \multicolumn{2}{|c|}{ Catholic } & \multicolumn{2}{|c|}{ Protestant } & \multicolumn{2}{|c|}{ Muslim } \\
\hline & (1) & (2) & (3) & (4) & (5) & (6) & (7) & (8) & (9) & (10) & (11) & (12) \\
\hline Treatment village & $\begin{array}{c}0.006 \\
{[0.024]}\end{array}$ & & $\begin{array}{c}-0.004 \\
{[0.016]}\end{array}$ & & $\begin{array}{c}-0.015 \\
{[0.016]}\end{array}$ & & $\begin{array}{c}0.005 \\
{[0.025]}\end{array}$ & & $\begin{array}{c}-0.013 \\
{[0.025]}\end{array}$ & & $\begin{array}{c}-0.018 \\
{[0.015]}\end{array}$ & \\
\hline Spillover & $\begin{array}{c}0.031 \\
{[0.030]}\end{array}$ & & $\begin{array}{c}-0.005 \\
{[0.017]}\end{array}$ & & $\begin{array}{l}-0.029^{*} \\
{[0.016]}\end{array}$ & & $\begin{array}{c}0.029 \\
{[0.029]}\end{array}$ & & $\begin{array}{c}-0.001 \\
{[0.028]}\end{array}$ & & $\begin{array}{c}-0.026 \\
{[0.016]}\end{array}$ & \\
\hline Treatment Saturation & & $\begin{array}{c}-0.003 \\
{[0.055]}\end{array}$ & & $\begin{array}{c}0.003 \\
{[0.029]}\end{array}$ & & $\begin{array}{c}-0.021 \\
{[0.035]}\end{array}$ & & $\begin{array}{c}0.033 \\
{[0.046]}\end{array}$ & & $\begin{array}{c}-0.023 \\
{[0.045]}\end{array}$ & & $\begin{array}{c}-0.043 \\
{[0.030]}\end{array}$ \\
\hline Outside Sampling Frame & $\begin{array}{c}-0.019 \\
{[0.022]}\end{array}$ & $\begin{array}{c}0.002 \\
{[0.008]}\end{array}$ & $\begin{array}{c}0.011 \\
{[0.012]}\end{array}$ & $\begin{array}{c}0.009 \\
{[0.008]}\end{array}$ & $\begin{array}{l}0.027^{* *} \\
{[0.011]}\end{array}$ & $\begin{array}{c}0.015^{* *} \\
{[0.007]}\end{array}$ & $\begin{array}{c}-0.021 \\
{[0.026]}\end{array}$ & $\begin{array}{c}-0.005 \\
{[0.017]}\end{array}$ & $\begin{array}{c}0.006 \\
{[0.025]}\end{array}$ & $\begin{array}{c}0.014 \\
{[0.017]}\end{array}$ & $\begin{array}{c}0.004 \\
{[0.013]}\end{array}$ & $\begin{array}{c}-0.002 \\
{[0.008]}\end{array}$ \\
\hline ACFIM Presence & $\begin{array}{c}0.177^{* * *} \\
{[0.048]}\end{array}$ & $\begin{array}{c}0.181^{* * *} \\
{[0.051]}\end{array}$ & $\begin{array}{c}-0.115^{* * *} \\
{[0.029]}\end{array}$ & $\begin{array}{c}-0.117^{* * *} \\
{[0.030]}\end{array}$ & $\begin{array}{c}0.051^{*} \\
{[0.028]}\end{array}$ & $\begin{array}{c}0.061^{*} \\
{[0.036]}\end{array}$ & $\begin{array}{c}0.011 \\
{[0.041]}\end{array}$ & $\begin{array}{c}-0.004 \\
{[0.048]}\end{array}$ & $\begin{array}{c}-0.034 \\
{[0.041]}\end{array}$ & $\begin{array}{c}-0.021 \\
{[0.046]}\end{array}$ & $\begin{array}{c}0.066^{* * *} \\
{[0.023]}\end{array}$ & $\begin{array}{c}0.088^{* * *} \\
{[0.031]}\end{array}$ \\
\hline $\begin{array}{l}R^{2} \\
\text { Control Mean } \\
\text { Observations }\end{array}$ & $\begin{array}{c}0.03 \\
0.095 \\
4090\end{array}$ & $\begin{array}{c}0.02 \\
0.095 \\
4090\end{array}$ & $\begin{array}{c}0.02 \\
0.063 \\
4090\end{array}$ & $\begin{array}{c}0.02 \\
0.063 \\
4090\end{array}$ & $\begin{array}{c}0.01 \\
0.063 \\
4090\end{array}$ & $\begin{array}{c}0.00 \\
0.063 \\
4090\end{array}$ & $\begin{array}{c}0.00 \\
0.449 \\
4090\end{array}$ & $\begin{array}{c}0.00 \\
0.449 \\
4090\end{array}$ & $\begin{array}{c}0.00 \\
0.421 \\
4090\end{array}$ & $\begin{array}{c}0.00 \\
0.421 \\
4090\end{array}$ & $\begin{array}{c}0.01 \\
0.091 \\
4090\end{array}$ & $\begin{array}{c}0.01 \\
0.091 \\
4090\end{array}$ \\
\hline
\end{tabular}

Note: Odd-numbered columns report estimates from equation (1) and even-numbered columns report estimates from equation (2). All dependent variables come from the key informant survey data (see text for details).

${ }^{*} \mathrm{p}<0.1,{ }^{* *} \mathrm{p}<0.05,{ }^{* * *} \mathrm{p}<0.01$. Standard errors clustered by parish in brackets. 
Table A7: Balance on Pre-determined Electoral Data

\begin{tabular}{|c|c|c|c|c|c|c|c|c|c|c|c|c|}
\hline & \multicolumn{2}{|c|}{ Reg'd Voters 2011} & \multicolumn{2}{|c|}{ Turnout 2011} & \multicolumn{2}{|c|}{ NRM Vote 2011} & \multicolumn{2}{|c|}{ FDC Vote 2011} & \multicolumn{2}{|c|}{ MP Incumbent Vote 2011} & \multicolumn{2}{|c|}{ Reg'd Voters 2016} \\
\hline & (1) & (2) & (3) & (4) & (5) & (6) & (7) & (8) & (9) & (10) & (11) & (12) \\
\hline Treatment Polling Station & $\begin{array}{c}-284.303 \\
{[196.161]}\end{array}$ & & $\begin{array}{c}0.004 \\
{[0.008]}\end{array}$ & & $\begin{array}{c}-0.010 \\
{[0.014]}\end{array}$ & & $\begin{array}{c}0.005 \\
{[0.013]}\end{array}$ & & $\begin{array}{l}-0.019 \\
{[0.015]}\end{array}$ & & $\begin{array}{c}-2.988 \\
{[10.425]}\end{array}$ & \\
\hline Spillover Polling Station & $\begin{array}{l}-374.461 \\
{[375.616]}\end{array}$ & & $\begin{array}{c}0.000 \\
{[0.009]}\end{array}$ & & $\begin{array}{c}-0.006 \\
{[0.017]}\end{array}$ & & $\begin{array}{c}-0.006 \\
{[0.015]}\end{array}$ & & $\begin{array}{c}-0.001 \\
{[0.016]}\end{array}$ & & $\begin{array}{l}-14.056 \\
{[9.117]}\end{array}$ & \\
\hline Treatment Saturation & & $\begin{array}{c}-699.026 \\
{[458.784]}\end{array}$ & & $\begin{array}{c}0.004 \\
{[0.018]}\end{array}$ & & $\begin{array}{c}-0.024 \\
{[0.029]}\end{array}$ & & $\begin{array}{c}0.013 \\
{[0.026]}\end{array}$ & & $\begin{array}{c}-0.035 \\
{[0.029]}\end{array}$ & & $\begin{array}{c}4.987 \\
{[17.359]}\end{array}$ \\
\hline Outside Sampling Frame & $\begin{array}{c}550.989^{* * *} \\
{[202.723]}\end{array}$ & $\begin{array}{c}512.567^{* * *} \\
{[121.113]}\end{array}$ & $\begin{array}{c}-0.021^{* * *} \\
{[0.005]}\end{array}$ & $\begin{array}{c}-0.023^{* * *} \\
{[0.004]}\end{array}$ & $\begin{array}{c}-0.025^{* * *} \\
{[0.008]}\end{array}$ & $\begin{array}{c}-0.023^{* * *} \\
{[0.006]}\end{array}$ & $\begin{array}{l}0.015^{* *} \\
{[0.007]}\end{array}$ & $\begin{array}{l}0.010^{* *} \\
{[0.005]}\end{array}$ & $\begin{array}{c}-0.019^{* *} \\
{[0.008]}\end{array}$ & $\begin{array}{l}-0.010^{*} \\
{[0.005]}\end{array}$ & $\begin{array}{c}-81.618^{* * *} \\
{[9.420]}\end{array}$ & $\begin{array}{c}-86.769^{* * *} \\
{[7.363]}\end{array}$ \\
\hline ACFIM Presence & $\begin{array}{c}-591.868 \\
{[440.937]}\end{array}$ & $\begin{array}{c}-298.382 \\
{[504.111]}\end{array}$ & $\begin{array}{c}-0.074^{* * *} \\
{[0.016]}\end{array}$ & $\begin{array}{c}-0.076^{* * *} \\
{[0.019]}\end{array}$ & $\begin{array}{c}-0.153^{* * *} \\
{[0.027]}\end{array}$ & $\begin{array}{c}-0.142^{* * *} \\
{[0.031]}\end{array}$ & $\begin{array}{c}0.036 \\
{[0.022]}\end{array}$ & $\begin{array}{c}0.029 \\
{[0.025]}\end{array}$ & $\begin{array}{c}-0.076^{* * *} \\
{[0.025]}\end{array}$ & $\begin{array}{c}-0.059^{* *} \\
{[0.029]}\end{array}$ & $\begin{array}{c}-45.561^{* * *} \\
{[15.677]}\end{array}$ & $\begin{array}{c}-49.449^{* * *} \\
{[18.111]}\end{array}$ \\
\hline$R^{2}$ & 0.04 & 0.04 & 0.03 & 0.03 & 0.04 & 0.04 & 0.00 & 0.00 & 0.01 & 0.01 & 0.04 & 0.04 \\
\hline Control Mean & 3007.687 & 3007.687 & 0.600 & 0.600 & 0.685 & 0.685 & 0.262 & 0.262 & 0.554 & 0.554 & 575.130 & 575.130 \\
\hline Observations & 3641 & 3641 & 3641 & 3641 & 3641 & 3641 & 3641 & 3641 & 3214 & 3214 & 3659 & 3659 \\
\hline
\end{tabular}

Note: Odd-numbered columns report estimates from equation (1) and even-numbered columns report estimates from equation (2). All dependent variables come from the official electoral data provided by the Ugandan Electoral Commission (see text for details).

${ }^{*} \mathrm{p}<0.1,{ }^{* *} \mathrm{p}<0.05,{ }^{* * *} \mathrm{p}<0.01$. Standard errors clustered by parish in brackets. 
Table A8: Main Effects of Treatment Saturation

\begin{tabular}{|c|c|c|c|c|c|c|c|c|c|c|}
\hline & $\begin{array}{l}\text { Vote-buying } \\
\text { (PAP Index) }\end{array}$ & $\begin{array}{l}\text { Vote-buying } \\
\text { (cash/kind) }\end{array}$ & $\begin{array}{c}\text { Vote for } \\
\text { incumbents }\end{array}$ & $\begin{array}{c}\text { Vote for } \\
\text { challengers }\end{array}$ & $\begin{array}{l}\text { Acceptability } \\
\text { of vote-buying }\end{array}$ & $\begin{array}{c}\text { Social } \\
\text { sanctions }\end{array}$ & $\begin{array}{c}\text { Vote-buying } \\
\text { by incumbents }\end{array}$ & $\begin{array}{l}\text { Vote-buying } \\
\text { by challengers }\end{array}$ & $\begin{array}{c}\text { Campaigning } \\
\text { by incumbents }\end{array}$ & $\begin{array}{l}\text { Campaigning } \\
\text { by challengers }\end{array}$ \\
\hline & (1) & (2) & (3) & (4) & (5) & (6) & (7) & (8) & (9) & (10) \\
\hline Treatment Saturation & $\begin{array}{c}-0.016 \\
{[0.066]}\end{array}$ & $\begin{array}{c}0.063 \\
{[0.045]}\end{array}$ & $\begin{array}{c}-0.184^{* * *} \\
{[0.064]}\end{array}$ & $\begin{array}{c}0.184^{* * *} \\
{[0.064]}\end{array}$ & $\begin{array}{c}-0.098^{* *} \\
{[0.043]}\end{array}$ & $\begin{array}{c}0.027 \\
{[0.018]}\end{array}$ & $\begin{array}{c}0.018 \\
{[0.047]}\end{array}$ & $\begin{array}{l}0.087^{*} \\
{[0.045]}\end{array}$ & $\begin{array}{c}0.092 \\
{[0.075]}\end{array}$ & $\begin{array}{l}0.179^{* *} \\
{[0.091]}\end{array}$ \\
\hline $\begin{array}{l}R^{2} \\
\text { Observations }\end{array}$ & $\begin{array}{c}0.16 \\
28454\end{array}$ & $\begin{array}{c}0.06 \\
28454\end{array}$ & $\begin{array}{c}0.09 \\
27065\end{array}$ & $\begin{array}{c}0.09 \\
27065\end{array}$ & $\begin{array}{c}0.03 \\
28454\end{array}$ & $\begin{array}{c}0.04 \\
28454\end{array}$ & $\begin{array}{c}0.06 \\
28454\end{array}$ & $\begin{array}{c}0.04 \\
28454\end{array}$ & $\begin{array}{c}0.13 \\
28454\end{array}$ & $\begin{array}{c}0.10 \\
28454\end{array}$ \\
\hline
\end{tabular}

Note: This table report estimates from equation (2). The dependent variables in each column are the same as those reported in Figure 2 (see text for details).

${ }^{*} \mathrm{p}<0.1,{ }^{* *} \mathrm{p}<0.05,{ }^{* * *} \mathrm{p}<0.01$. Standard errors clustered by parish in brackets. 
Table A9: Effects of the Campaign on Vote Buying: Any Cash Received (Individual level)

\begin{tabular}{|c|c|c|c|c|c|c|}
\hline & \multicolumn{2}{|c|}{ All Candidates } & \multicolumn{2}{|c|}{ Incumbents } & \multicolumn{2}{|c|}{ All Challengers } \\
\hline & (1) & $(2)$ & (3) & $(4)$ & (5) & (6) \\
\hline Treatment village & $\begin{array}{c}0.020 \\
{[0.019]}\end{array}$ & & $\begin{array}{c}0.002 \\
{[0.015]}\end{array}$ & & $\begin{array}{c}0.022^{*} \\
{[0.012]}\end{array}$ & \\
\hline Spillover & $\begin{array}{c}0.028 \\
{[0.021]}\end{array}$ & & $\begin{array}{c}0.004 \\
{[0.017]}\end{array}$ & & $\begin{array}{l}0.029^{* *} \\
{[0.013]}\end{array}$ & \\
\hline Treatment Saturation & & $\begin{array}{c}0.048 \\
{[0.033]}\end{array}$ & & $\begin{array}{c}0.017 \\
{[0.026]}\end{array}$ & & $\begin{array}{c}0.040^{*} \\
{[0.024]}\end{array}$ \\
\hline Outside Sampling Frame & $\begin{array}{c}-0.013 \\
{[0.020]}\end{array}$ & $\begin{array}{c}-0.008 \\
{[0.014]}\end{array}$ & $\begin{array}{c}-0.000 \\
{[0.015]}\end{array}$ & $\begin{array}{c}0.000 \\
{[0.011]}\end{array}$ & $\begin{array}{c}-0.016 \\
{[0.012]}\end{array}$ & $\begin{array}{c}-0.009 \\
{[0.007]}\end{array}$ \\
\hline ACFIM Presence & $\begin{array}{c}-0.035 \\
{[0.034]}\end{array}$ & $\begin{array}{c}-0.060 \\
{[0.037]}\end{array}$ & $\begin{array}{c}-0.037 \\
{[0.026]}\end{array}$ & $\begin{array}{c}-0.046 \\
{[0.029]}\end{array}$ & $\begin{array}{c}0.017 \\
{[0.025]}\end{array}$ & $\begin{array}{c}-0.003 \\
{[0.023]}\end{array}$ \\
\hline$R^{2}$ & 0.13 & 0.13 & 0.11 & 0.11 & 0.08 & 0.08 \\
\hline Control Mean & 0.43 & 0.43 & 0.33 & 0.33 & 0.16 & 0.16 \\
\hline Controls & Yes & Yes & Yes & Yes & Yes & Yes \\
\hline Observations & 28454 & 28454 & 28454 & 28454 & 28454 & 28454 \\
\hline
\end{tabular}

Note: All regressions include a dummy for out-of-sample villages and control for the parish-level ACFIM presence. The dependent variable is the sum of indicators for any vote buying by candidates in the presidential and parliamentary races. The range of the first outcome is $0-4$ and the range of the second and third outcomes is 0 to 2 .

${ }^{*} \mathrm{p}<0.1,{ }^{* *} \mathrm{p}<0.05,{ }^{* * *} \mathrm{p}<0.01$. Standard errors clustered by parish in brackets. 
Table A10: Effects of the Campaign on Vote Buying: Log Cash Received (Individual Level)

\begin{tabular}{|c|c|c|c|c|c|c|}
\hline & \multicolumn{2}{|c|}{ All Candidates } & \multicolumn{2}{|c|}{ Incumbents } & \multicolumn{2}{|c|}{ All Challengers } \\
\hline & (1) & (2) & (3) & (4) & (5) & (6) \\
\hline Treatment village & $\begin{array}{c}0.012 \\
{[0.095]}\end{array}$ & & $\begin{array}{c}-0.009 \\
{[0.088]}\end{array}$ & & $\begin{array}{l}0.129^{*} \\
{[0.076]}\end{array}$ & \\
\hline Spillover & $\begin{array}{c}0.102 \\
{[0.107]}\end{array}$ & & $\begin{array}{c}0.026 \\
{[0.101]}\end{array}$ & & $\begin{array}{l}0.218^{* *} \\
{[0.086]}\end{array}$ & \\
\hline Treatment Saturation & & $\begin{array}{c}0.083 \\
{[0.161]}\end{array}$ & & $\begin{array}{c}0.044 \\
{[0.149]}\end{array}$ & & $\begin{array}{l}0.239^{*} \\
{[0.140]}\end{array}$ \\
\hline Frame & $\begin{array}{l}-0.068 \\
{[0.099]}\end{array}$ & $\begin{array}{c}-0.006 \\
{[0.071]}\end{array}$ & $\begin{array}{c}0.022 \\
{[0.093]}\end{array}$ & $\begin{array}{c}0.041 \\
{[0.067]}\end{array}$ & $\begin{array}{l}-0.120 \\
{[0.077]}\end{array}$ & $\begin{array}{c}-0.047 \\
{[0.047]}\end{array}$ \\
\hline ACFIM Presence & $\begin{array}{c}-0.309^{*} \\
{[0.168]}\end{array}$ & $\begin{array}{c}-0.346^{*} \\
{[0.182]} \\
\end{array}$ & $\begin{array}{c}-0.304^{* *} \\
{[0.154]} \\
\end{array}$ & $\begin{array}{c}-0.326^{*} \\
{[0.171]}\end{array}$ & $\begin{array}{c}0.071 \\
{[0.142]} \\
\end{array}$ & $\begin{array}{c}-0.047 \\
{[0.146]} \\
\end{array}$ \\
\hline$R^{2}$ & 0.12 & 0.12 & 0.11 & 0.11 & 0.07 & 0.07 \\
\hline Control Mean & 2.58 & 2.58 & 2.14 & 2.14 & 1.12 & 1.12 \\
\hline & Yes & Yes & Ye & Yes & Ye & Yes \\
\hline Observations & 28454 & 28454 & 28454 & 28454 & 28454 & 28454 \\
\hline
\end{tabular}

Note: All regressions include a dummy for out-of-sample villages and control for the parish-level ACFIM presence. The dependent variables are equal to the natural $\log +1$ of the amount of cash received by the respondent from candidates in the presidential and parliamentary races, measured for any candidate (cols. 1-2) and separately for incumbents (cols. 3-4) and challenger candidates (cols. 5-6).

${ }^{*} \mathrm{p}<0.1,{ }^{* *} \mathrm{p}<0.05,{ }^{* * *} \mathrm{p}<0.01$. Standard errors clustered by parish in brackets. 
Table A11: Effects of the Campaign on Vote Buying: Any Cash Received (Village level)

\begin{tabular}{|c|c|c|c|c|c|c|}
\hline & \multicolumn{2}{|c|}{ All Candidates } & \multicolumn{2}{|c|}{ Incumbents } & \multicolumn{2}{|c|}{ Challengers } \\
\hline & $(1)$ & $(2)$ & (3) & (4) & (5) & (6) \\
\hline Treatment village & $\begin{array}{c}0.026 \\
{[0.056]}\end{array}$ & & $\begin{array}{l}-0.000 \\
{[0.043]}\end{array}$ & & $\begin{array}{c}0.050 \\
{[0.041]}\end{array}$ & \\
\hline Spillover & $\begin{array}{c}0.076 \\
{[0.066]}\end{array}$ & & $\begin{array}{l}-0.005 \\
{[0.048]}\end{array}$ & & $\begin{array}{l}0.095^{* *} \\
{[0.046]}\end{array}$ & \\
\hline Treatment Saturation & & $\begin{array}{c}0.019 \\
{[0.110]}\end{array}$ & & $\begin{array}{l}-0.018 \\
{[0.082]}\end{array}$ & & $\begin{array}{c}0.094 \\
{[0.080]}\end{array}$ \\
\hline Outside Sampling Frame & $\begin{array}{c}-0.113^{* *} \\
{[0.057]}\end{array}$ & $\begin{array}{c}-0.072^{* *} \\
{[0.031]}\end{array}$ & $\begin{array}{l}-0.040 \\
{[0.040]}\end{array}$ & $\begin{array}{l}-0.042^{*} \\
{[0.025]}\end{array}$ & $\begin{array}{c}-0.107^{* * *} \\
{[0.040]}\end{array}$ & $\begin{array}{c}-0.071^{* * *} \\
{[0.022]}\end{array}$ \\
\hline ACFIM Presence & $\begin{array}{c}-0.398^{* * *} \\
{[0.099]}\end{array}$ & $\begin{array}{c}-0.402^{* * *} \\
{[0.104]}\end{array}$ & $\begin{array}{c}-0.361^{* * *} \\
{[0.072]}\end{array}$ & $\begin{array}{c}-0.352^{* * *} \\
{[0.079]}\end{array}$ & $\begin{array}{c}-0.149^{* *} \\
{[0.075]}\end{array}$ & $\begin{array}{c}-0.194^{* * *} \\
{[0.074]}\end{array}$ \\
\hline$R^{2}$ & 0.06 & 0.05 & 0.05 & 0.05 & 0.05 & 0.05 \\
\hline Control Mean & 1.216 & 1.216 & 0.919 & 0.919 & 0.595 & 0.595 \\
\hline Observations & 4111 & 4111 & 4111 & 4111 & 4111 & 4111 \\
\hline
\end{tabular}

Note: All regressions include a dummy for out-of-sample villages and control for the parish-level ACFIM presence. Each dependent variable is the sum of dummies for each individual (presidential or parliamentary) race. All Candidates ranges from 0 to 15 , while the other dependent variables range from 0 to 2 .

${ }^{*} \mathrm{p}<0.1,{ }^{* *} \mathrm{p}<0.05,{ }^{* * *} \mathrm{p}<0.01$. Standard errors clustered by parish in brackets. 
Table A12: Electoral Checks - Rounding

\begin{tabular}{|c|c|c|c|c|c|c|c|c|c|c|c|c|c|c|c|c|}
\hline & \multicolumn{4}{|c|}{ Presidential (Total Valid) } & \multicolumn{4}{|c|}{ MP (Total Valid) } & \multicolumn{4}{|c|}{ Presidential (Incumbent Vote) } & \multicolumn{4}{|c|}{ MP (Incumbent Vote) } \\
\hline & (1) & (2) & (3) & (4) & (5) & (6) & (7) & (8) & (9) & (10) & (11) & (12) & (13) & (14) & (15) & (16) \\
\hline & 0 & 0 & 5 & 5 & 0 & 0 & 5 & 5 & 0 & 0 & 5 & 5 & 0 & 0 & 5 & 5 \\
\hline Treatment Polling Station & $\begin{array}{c}-0.00 \\
{[0.02]}\end{array}$ & & $\begin{array}{c}-0.02 \\
{[0.02]}\end{array}$ & & $\begin{array}{c}0.02 \\
{[0.03]}\end{array}$ & & $\begin{array}{c}0.01 \\
{[0.02]}\end{array}$ & & $\begin{array}{c}0.01 \\
{[0.02]}\end{array}$ & & $\begin{array}{c}-0.00 \\
{[0.02]}\end{array}$ & & $\begin{array}{c}0.03 \\
{[0.03]}\end{array}$ & & $\begin{array}{c}-0.01 \\
{[0.02]}\end{array}$ & \\
\hline Spillover Polling Station & $\begin{array}{c}-0.02^{*} \\
{[0.01]}\end{array}$ & & $\begin{array}{c}-0.00 \\
{[0.01]}\end{array}$ & & $\begin{array}{c}0.05 \\
{[0.03]}\end{array}$ & & $\begin{array}{c}-0.01 \\
{[0.01]}\end{array}$ & & $\begin{array}{c}0.00 \\
{[0.01]}\end{array}$ & & $\begin{array}{c}-0.02 \\
{[0.01]}\end{array}$ & & $\begin{array}{c}0.05 \\
{[0.03]}\end{array}$ & & $\begin{array}{c}-0.00 \\
{[0.01]}\end{array}$ & \\
\hline Saturation & & $\begin{array}{c}-0.00 \\
{[0.02]}\end{array}$ & & $\begin{array}{c}-0.04 \\
{[0.03]}\end{array}$ & & $\begin{array}{c}0.05 \\
{[0.06]}\end{array}$ & & $\begin{array}{c}-0.00 \\
{[0.02]}\end{array}$ & & $\begin{array}{c}0.02 \\
{[0.02]}\end{array}$ & & $\begin{array}{c}0.02 \\
{[0.02]}\end{array}$ & & $\begin{array}{c}0.10 \\
{[0.06]}\end{array}$ & & $\begin{array}{c}0.02 \\
{[0.02]}\end{array}$ \\
\hline Outside Sampling Frame & $\begin{array}{c}-0.01 \\
{[0.01]}\end{array}$ & $\begin{array}{c}-0.01 \\
{[0.01]}\end{array}$ & $\begin{array}{c}-0.00 \\
{[0.02]}\end{array}$ & $\begin{array}{c}0.00 \\
{[0.01]}\end{array}$ & $\begin{array}{c}-0.04^{* *} \\
{[0.02]}\end{array}$ & $\begin{array}{c}-0.03^{*} \\
{[0.02]}\end{array}$ & $\begin{array}{c}-0.02 \\
{[0.01]}\end{array}$ & $\begin{array}{c}-0.03^{* * *} \\
{[0.01]}\end{array}$ & $\begin{array}{c}-0.01 \\
{[0.01]}\end{array}$ & $\begin{array}{c}-0.01 \\
{[0.01]}\end{array}$ & $\begin{array}{c}-0.00 \\
{[0.02]}\end{array}$ & $\begin{array}{c}-0.01 \\
{[0.01]}\end{array}$ & $\begin{array}{c}-0.05^{* *} \\
{[0.02]}\end{array}$ & $\begin{array}{c}-0.04^{* * *} \\
{[0.02]}\end{array}$ & $\begin{array}{c}-0.00 \\
{[0.01]}\end{array}$ & $\begin{array}{c}0.00 \\
{[0.01]}\end{array}$ \\
\hline ACFIM Presence & $\begin{array}{c}-0.02 \\
{[0.02]}\end{array}$ & $\begin{array}{c}-0.03 \\
{[0.02]}\end{array}$ & $\begin{array}{c}-0.01 \\
{[0.02]}\end{array}$ & $\begin{array}{c}0.01 \\
{[0.03]}\end{array}$ & $\begin{array}{c}-0.11^{* *} \\
{[0.05]}\end{array}$ & $\begin{array}{c}-0.13^{* *} \\
{[0.06]}\end{array}$ & $\begin{array}{c}0.02 \\
{[0.02]}\end{array}$ & $\begin{array}{c}0.01 \\
{[0.03]}\end{array}$ & $\begin{array}{c}-0.01 \\
{[0.02]}\end{array}$ & $\begin{array}{c}-0.02 \\
{[0.03]}\end{array}$ & $\begin{array}{c}-0.03 \\
{[0.02]}\end{array}$ & $\begin{array}{c}-0.04 \\
{[0.02]}\end{array}$ & $\begin{array}{c}-0.11^{* *} \\
{[0.06]}\end{array}$ & $\begin{array}{c}-0.15^{* * *} \\
{[0.06]}\end{array}$ & $\begin{array}{c}-0.01 \\
{[0.02]}\end{array}$ & $\begin{array}{c}-0.01 \\
{[0.02]}\end{array}$ \\
\hline$R^{2}$ & 0.00 & 0.00 & 0.00 & 0.00 & 0.04 & 0.04 & 0.01 & 0.01 & 0.00 & 0.00 & 0.00 & 0.00 & 0.04 & 0.04 & 0.00 & 0.00 \\
\hline Control Mean & 0.100 & 0.100 & 0.105 & 0.105 & 0.202 & 0.202 & 0.091 & 0.091 & 0.100 & 0.100 & 0.093 & 0.093 & 0.223 & 0.223 & 0.080 & 0.080 \\
\hline Contro & Yes & Yes & Yes & Yes & Yes & Yes & Yes & Yes & Yes & Yes & Yes & Yes & Yes & Yes & Yes & Yes \\
\hline Observations & 3192 & 3192 & 3192 & 3192 & 3192 & 3192 & 3192 & 3192 & 3192 & 3192 & 3192 & 3192 & 3192 & 3192 & 3192 & 3192 \\
\hline
\end{tabular}

Note: This table tests whether treatment status and parish-level treatment saturation correlate with the likelihood that vote counts were rounded to 0 or 5 in the electoral data. Vote counts are measured as total valid votes in columns 1-8, and valid as votes for incumbents in columns 9-16.

${ }^{*} \mathrm{p}<0.1,{ }^{* *} \mathrm{p}<0.05,{ }^{* * *} \mathrm{p}<0.01$. Standard errors clustered by parish in brackets. 


\section{Table A13: Electoral Checks - Abnormal Returns}

\begin{tabular}{|c|c|c|c|c|c|c|}
\hline & \multicolumn{2}{|c|}{ Above 2SD, Pres } & \multicolumn{2}{|c|}{ Above 2SD, MP } & \multicolumn{2}{|c|}{ Above 2SD, Both } \\
\hline & (1) & (2) & (3) & (4) & (5) & (6) \\
\hline Treatment Polling Station & $\begin{array}{c}0.001 \\
{[0.002]}\end{array}$ & & $\begin{array}{c}0.045 \\
{[0.031]}\end{array}$ & & $\begin{array}{c}-0.000 \\
{[0.000]}\end{array}$ & \\
\hline Spillover Polling Station & $\begin{array}{c}-0.000 \\
{[0.002]}\end{array}$ & & $\begin{array}{l}0.062^{* *} \\
{[0.030]}\end{array}$ & & $\begin{array}{c}-0.001 \\
{[0.001]}\end{array}$ & \\
\hline Saturation & & $\begin{array}{c}0.004 \\
{[0.003]}\end{array}$ & & $\begin{array}{c}0.090 \\
{[0.062]}\end{array}$ & & $\begin{array}{c}-0.000 \\
{[0.000]}\end{array}$ \\
\hline Outside Sampling Frame & $\begin{array}{c}-0.002 \\
{[0.002]}\end{array}$ & $\begin{array}{c}-0.002 \\
{[0.002]}\end{array}$ & $\begin{array}{c}-0.040^{* *} \\
{[0.016]}\end{array}$ & $\begin{array}{c}-0.033^{* * *} \\
{[0.011]}\end{array}$ & $\begin{array}{c}0.001 \\
{[0.001]}\end{array}$ & $\begin{array}{c}0.000 \\
{[0.000]}\end{array}$ \\
\hline ACFIM Presence & $\begin{array}{c}-0.001 \\
{[0.003]}\end{array}$ & $\begin{array}{c}-0.003 \\
{[0.003]}\end{array}$ & $\begin{array}{c}-0.106^{* *} \\
{[0.053]}\end{array}$ & $\begin{array}{c}-0.143^{* *} \\
{[0.056]}\end{array}$ & $\begin{array}{c}-0.001 \\
{[0.001]}\end{array}$ & $\begin{array}{c}-0.001 \\
{[0.001]}\end{array}$ \\
\hline$R^{2}$ & 0.01 & 0.01 & 0.07 & 0.06 & 0.00 & 0.00 \\
\hline Control Mean & 0.001 & 0.001 & 0.110 & 0.110 & 0.001 & 0.001 \\
\hline Controls & Yes & Yes & Yes & Yes & Yes & Yes \\
\hline Observations & 3192 & 3192 & 3192 & 3192 & 3192 & 3192 \\
\hline
\end{tabular}

Note: This table tests whether abormal voting returns correlate with treatment status and parish-level treatment saturation. Abnormal returns are defined as returns were both voter turnout and vote tallies for incumbents are 2SD above the mean in the electoral data, for the presidential race (columns 1-2), parliamentary races (columns 3-4), or both races (columns 5-6). ${ }^{*} \mathrm{p}<0.1,{ }^{* *} \mathrm{p}<0.05,{ }^{* *} \mathrm{p}<0.01$. Standard errors clustered by parish in brackets. 


\section{Table A14: Campaign Effects, Primary Hypotheses (Overall Vote Buying)}

\begin{tabular}{|c|c|c|c|c|}
\hline & \multicolumn{4}{|c|}{ Index for Hypotheses $1 \& 2$} \\
\hline & (1) & (2) & (3) & (4) \\
\hline Treatment village & $\begin{array}{c}-0.030 \\
{[0.038]}\end{array}$ & & $\begin{array}{c}-0.102 \\
{[0.083]}\end{array}$ & $\begin{array}{l}-0.085 \\
{[0.068]}\end{array}$ \\
\hline Spillover & $\begin{array}{c}0.023 \\
{[0.046]}\end{array}$ & & $\begin{array}{c}0.040 \\
{[0.086]}\end{array}$ & $\begin{array}{c}0.079 \\
{[0.080]}\end{array}$ \\
\hline Treatment Saturation & & $\begin{array}{c}-0.017 \\
{[0.067]}\end{array}$ & & \\
\hline Treatment ${ }^{*}$ Saturation & & & $\begin{array}{l}-0.046 \\
{[0.169]}\end{array}$ & $\begin{array}{c}0.118 \\
{[0.121]}\end{array}$ \\
\hline Spillover*Saturation & & & $\begin{array}{c}0.019 \\
{[0.240]}\end{array}$ & $\begin{array}{l}-0.180 \\
{[0.204]}\end{array}$ \\
\hline Outside Sampling Frame & $\begin{array}{c}-0.060 \\
{[0.043]}\end{array}$ & $\begin{array}{c}-0.026 \\
{[0.030]}\end{array}$ & $\begin{array}{c}-0.077 \\
{[0.052]}\end{array}$ & $\begin{array}{c}-0.145^{*} \\
{[0.087]}\end{array}$ \\
\hline ACFIM Presence & $\begin{array}{c}-0.132^{* *} \\
{[0.064]}\end{array}$ & $\begin{array}{c}-0.119 \\
{[0.076]}\end{array}$ & $\begin{array}{c}-0.180 \\
{[0.114]}\end{array}$ & $\begin{array}{c}0.020 \\
{[0.185]}\end{array}$ \\
\hline ACFIM Presence*Treatment & & & $\begin{array}{c}0.174 \\
{[0.199]}\end{array}$ & \\
\hline ACFIM Presence*Spillover & & & $\begin{array}{c}-0.041 \\
{[0.222]}\end{array}$ & \\
\hline ACFIM Village*ACFIM Presence & & & & $\begin{array}{c}-0.211 \\
{[0.191]}\end{array}$ \\
\hline$R^{2}$ & 0.16 & 0.16 & 0.16 & 0.16 \\
\hline Control Mean & 0.037 & 0.037 & 0.037 & 0.037 \\
\hline Controls & Yes & Yes & Yes & Yes \\
\hline Observations & 28454 & 28454 & 28454 & 28454 \\
\hline
\end{tabular}

Note: This table reports experimental results for Hypotheses 1 \& 2 in our pre-analysis plan: the campaign reduces the equilibrium number of votes sold in treatment villages (H1), and weakly increases the equilibrium number of votes sold in spillover villages $(\mathrm{H} 2)$. The dependent variable is our pre-specified index of vote buying.

${ }^{*} \mathrm{p}<0.1,{ }^{* *} \mathrm{p}<0.05,{ }^{* * *} \mathrm{p}<0.01$. Standard errors clustered by parish in brackets. 
Table A15: Campaign Effects, Hypothesis 3A (Supply of Votes)

\begin{tabular}{|c|c|c|c|c|}
\hline & \multicolumn{4}{|c|}{ Index for Hypothesis 3A } \\
\hline & (1) & (2) & (3) & (4) \\
\hline Treatment village & $\begin{array}{c}-0.059^{* *} \\
{[0.025]}\end{array}$ & & $\begin{array}{c}-0.028 \\
{[0.055]}\end{array}$ & $\begin{array}{c}-0.043 \\
{[0.046]}\end{array}$ \\
\hline Spillover & $\begin{array}{l}-0.026 \\
{[0.029]}\end{array}$ & & $\begin{array}{c}0.076 \\
{[0.052]}\end{array}$ & $\begin{array}{c}-0.014 \\
{[0.047]}\end{array}$ \\
\hline Treatment Saturation & & $\begin{array}{c}-0.096^{* *} \\
{[0.043]}\end{array}$ & & \\
\hline Treatment ${ }^{*}$ Saturation & & & $\begin{array}{c}-0.021 \\
{[0.123]}\end{array}$ & $\begin{array}{c}-0.033 \\
{[0.082]}\end{array}$ \\
\hline Spillover*Saturation & & & $\begin{array}{c}0.102 \\
{[0.141]}\end{array}$ & $\begin{array}{c}-0.043 \\
{[0.115]}\end{array}$ \\
\hline Outside Sampling Frame & $\begin{array}{l}-0.010 \\
{[0.029]}\end{array}$ & $\begin{array}{c}0.010 \\
{[0.022]}\end{array}$ & $\begin{array}{c}-0.032 \\
{[0.033]}\end{array}$ & $\begin{array}{c}0.036 \\
{[0.055]}\end{array}$ \\
\hline ACFIM Presence & $\begin{array}{c}0.041 \\
{[0.040]}\end{array}$ & $\begin{array}{l}0.094^{*} \\
{[0.049]}\end{array}$ & $\begin{array}{c}0.125^{*} \\
{[0.071]}\end{array}$ & $\begin{array}{c}-0.016 \\
{[0.109]}\end{array}$ \\
\hline ACFIM Presence ${ }^{*}$ Treatment & & & $\begin{array}{c}-0.054 \\
{[0.141]}\end{array}$ & \\
\hline ACFIM Presence*Spillover & & & $\begin{array}{c}-0.278^{* *} \\
{[0.137]}\end{array}$ & \\
\hline ACFIM Village*ACFIM Presence & & & & $\begin{array}{c}0.102 \\
{[0.114]}\end{array}$ \\
\hline$R^{2}$ & 0.03 & 0.03 & 0.03 & 0.03 \\
\hline Control Mean & 0.046 & 0.046 & 0.046 & 0.046 \\
\hline Controls & Yes & Yes & Yes & Yes \\
\hline Observations & 28454 & 28454 & 28454 & 28454 \\
\hline
\end{tabular}

Note: This table reports experimental results for Hypothesis 3A in our pre-analysis plan: the campaign reduces the supply of votes in treatment villages. The dependent variable is an index of the perceived fraction of village residents who would sell their vote at given price points and of the perceived acceptability of selling one's vote in the vignette experiment. ${ }^{*} \mathrm{p}<0.1,{ }^{* *} \mathrm{p}<0.05,{ }^{* * *} \mathrm{p}<0.01$. Standard errors clustered by parish in brackets. 
Table A16: Campaign Effects, Hypotheses 3B \& 5 (Demand for Votes)

\begin{tabular}{|c|c|c|c|c|}
\hline & \multicolumn{4}{|c|}{ Index for Hypothesis 3B } \\
\hline & (1) & (2) & (3) & (4) \\
\hline Treatment village & $\begin{array}{c}-0.002 \\
{[0.033]}\end{array}$ & & $\begin{array}{c}-0.062 \\
{[0.069]}\end{array}$ & $\begin{array}{c}-0.073 \\
{[0.054]}\end{array}$ \\
\hline Spillover & $\begin{array}{c}0.018 \\
{[0.038]}\end{array}$ & & $\begin{array}{c}0.023 \\
{[0.068]}\end{array}$ & $\begin{array}{c}0.015 \\
{[0.071]}\end{array}$ \\
\hline Treatment Saturation & & $\begin{array}{c}0.038 \\
{[0.061]}\end{array}$ & & \\
\hline Treatment*Saturation & & & $\begin{array}{c}0.176 \\
{[0.127]}\end{array}$ & $\begin{array}{c}0.151 \\
{[0.101]}\end{array}$ \\
\hline Spillover*Saturation & & & $\begin{array}{c}0.050 \\
{[0.208]}\end{array}$ & $\begin{array}{c}0.019 \\
{[0.176]}\end{array}$ \\
\hline Outside Sampling Frame & $\begin{array}{l}-0.046 \\
{[0.033]}\end{array}$ & $\begin{array}{c}-0.035^{*} \\
{[0.020]}\end{array}$ & $\begin{array}{c}-0.061^{*} \\
{[0.036]}\end{array}$ & $\begin{array}{c}-0.064 \\
{[0.070]}\end{array}$ \\
\hline ACFIM Presence & $\begin{array}{c}-0.080 \\
{[0.057]}\end{array}$ & $\begin{array}{c}-0.100 \\
{[0.065]}\end{array}$ & $\begin{array}{c}-0.123 \\
{[0.097]}\end{array}$ & $\begin{array}{c}-0.125 \\
{[0.145]}\end{array}$ \\
\hline ACFIM Presence*Treatment & & & $\begin{array}{c}-0.046 \\
{[0.154]}\end{array}$ & \\
\hline ACFIM Presence*Spillover & & & $\begin{array}{c}-0.038 \\
{[0.189]}\end{array}$ & \\
\hline ACFIM Village*ACFIM Presence & & & & $\begin{array}{c}-0.015 \\
{[0.146]}\end{array}$ \\
\hline$R^{2}$ & 0.19 & 0.19 & 0.19 & 0.19 \\
\hline Control Mean & 0.025 & 0.025 & 0.025 & 0.025 \\
\hline Controls & Yes & Yes & Yes & Yes \\
\hline Observations & 28353 & 28353 & 28353 & 28353 \\
\hline
\end{tabular}

Note: This table reports experimental results for Hypothesis 3B in our pre-analysis plan: the campaign affects the demand for votes in treatment villages. The dependent variable is an index capturing offers made by brokers of votes (accepted and rejected).

${ }^{*} \mathrm{p}<0.1,{ }^{* *} \mathrm{p}<0.05,{ }^{* * *} \mathrm{p}<0.01$. Standard errors clustered by parish in brackets. 


\section{Table A17: Campaign Effects, Hypotheses 4 \& 6 (Price of Votes)}

\begin{tabular}{|c|c|c|c|c|}
\hline & \multicolumn{4}{|c|}{ Index for Hypothesis 4_1 } \\
\hline & (1) & (2) & (3) & (4) \\
\hline Treatment village & $\begin{array}{c}0.012 \\
{[0.020]}\end{array}$ & & $\begin{array}{c}0.021 \\
{[0.044]}\end{array}$ & $\begin{array}{c}0.026 \\
{[0.037]}\end{array}$ \\
\hline Spillover & $\begin{array}{c}0.029 \\
{[0.023]}\end{array}$ & & $\begin{array}{c}0.023 \\
{[0.042]}\end{array}$ & $\begin{array}{c}0.024 \\
{[0.041]}\end{array}$ \\
\hline Treatment Saturation & & $\begin{array}{c}0.017 \\
{[0.033]}\end{array}$ & & \\
\hline Treatment ${ }^{*}$ Saturation & & & $\begin{array}{c}-0.040 \\
{[0.094]}\end{array}$ & $\begin{array}{c}-0.029 \\
{[0.064]}\end{array}$ \\
\hline Spillover*Saturation & & & $\begin{array}{c}0.006 \\
{[0.112]}\end{array}$ & $\begin{array}{c}0.016 \\
{[0.101]}\end{array}$ \\
\hline Outside Sampling Frame & $\begin{array}{c}-0.018 \\
{[0.021]}\end{array}$ & $\begin{array}{c}-0.004 \\
{[0.014]}\end{array}$ & $\begin{array}{c}-0.017 \\
{[0.024]}\end{array}$ & $\begin{array}{c}-0.013 \\
{[0.044]}\end{array}$ \\
\hline ACFIM Presence & $\begin{array}{c}-0.052 \\
{[0.037]}\end{array}$ & $\begin{array}{c}-0.059 \\
{[0.042]}\end{array}$ & $\begin{array}{c}-0.049 \\
{[0.058]}\end{array}$ & $\begin{array}{c}-0.051 \\
{[0.097]}\end{array}$ \\
\hline ACFIM Presence*Treatment & & & $\begin{array}{c}0.020 \\
{[0.107]}\end{array}$ & \\
\hline ACFIM Presence ${ }^{*}$ pillover & & & $\begin{array}{c}0.009 \\
{[0.108]}\end{array}$ & \\
\hline ACFIM Village*ACFIM Presence & & & & $\begin{array}{c}0.009 \\
{[0.098]}\end{array}$ \\
\hline$R^{2}$ & 0.09 & 0.09 & 0.09 & 0.09 \\
\hline Control Mean & 0.003 & 0.003 & 0.003 & 0.003 \\
\hline Controls & Yes & Yes & Yes & Yes \\
\hline Observations & 28454 & 28454 & 28454 & 28454 \\
\hline
\end{tabular}

Note: This table reports experimental results for Hypothesis 4 in our pre-analysis plan: the campaign increases or decreases the price of votes in treatment villages, depending on the relative magnitude of supply and demand shocks. The dependent variable is the sum of all gifts received by the respondent in cash or in kind, by all candidates.

${ }^{*} \mathrm{p}<0.1,{ }^{* *} \mathrm{p}<0.05,{ }^{* * *} \mathrm{p}<0.01$. Standard errors clustered by parish in brackets. 
Table A18: Campaign Effects, Hypotheses 4 \& 6 (Price of Votes)

\begin{tabular}{|c|c|c|c|c|}
\hline & \multicolumn{4}{|c|}{ Index for Hypothesis $4 \_2$} \\
\hline & (1) & (2) & (3) & (4) \\
\hline Treatment village & $\begin{array}{c}0.002 \\
{[0.026]}\end{array}$ & & $\begin{array}{c}-0.003 \\
{[0.059]}\end{array}$ & $\begin{array}{c}-0.009 \\
{[0.047]}\end{array}$ \\
\hline Spillover & $\begin{array}{c}-0.041 \\
{[0.033]}\end{array}$ & & $\begin{array}{c}-0.028 \\
{[0.070]}\end{array}$ & $\begin{array}{c}-0.040 \\
{[0.058]}\end{array}$ \\
\hline Treatment Saturation & & $\begin{array}{l}-0.007 \\
{[0.042]}\end{array}$ & & \\
\hline Treatment*Saturation & & & $\begin{array}{c}0.130 \\
{[0.125]}\end{array}$ & $\begin{array}{c}0.023 \\
{[0.081]}\end{array}$ \\
\hline Spillover*Saturation & & & $\begin{array}{l}-0.178 \\
{[0.138]}\end{array}$ & $\begin{array}{c}-0.005 \\
{[0.135]}\end{array}$ \\
\hline Outside Sampling Frame & $\begin{array}{c}0.044 \\
{[0.033]}\end{array}$ & $\begin{array}{c}0.013 \\
{[0.024]}\end{array}$ & $\begin{array}{c}0.061 \\
{[0.041]}\end{array}$ & $\begin{array}{c}0.100 \\
{[0.069]}\end{array}$ \\
\hline ACFIM Presence & $\begin{array}{c}-0.096^{* *} \\
{[0.044]}\end{array}$ & $\begin{array}{l}-0.095^{*} \\
{[0.052]}\end{array}$ & $\begin{array}{c}-0.088 \\
{[0.075]}\end{array}$ & $\begin{array}{c}-0.209 \\
{[0.141]}\end{array}$ \\
\hline ACFIM Presence*Treatment & & & $\begin{array}{l}-0.101 \\
{[0.147]}\end{array}$ & \\
\hline ACFIM Presence*Spillover & & & $\begin{array}{c}0.081 \\
{[0.144]}\end{array}$ & \\
\hline ACFIM Village ${ }^{*}$ ACFIM Presence & & & & $\begin{array}{c}0.140 \\
{[0.148]}\end{array}$ \\
\hline$R^{2}$ & 0.07 & 0.07 & 0.07 & 0.07 \\
\hline Control Mean & -0.003 & -0.003 & -0.003 & -0.003 \\
\hline Controls & Yes & Yes & Yes & Yes \\
\hline Observations & 28440 & 28440 & 28440 & 28440 \\
\hline
\end{tabular}

Note: This table reports experimental results for Hypothesis 4 in our pre-analysis plan: the campaign increases or decreases the price of votes in treatment villages, depending on the relative magnitude of supply and demand shocks. The dependent variable is an index of typical gift amounts offered by different candidates in the village.

${ }^{*} \mathrm{p}<0.1,{ }^{* *} \mathrm{p}<0.05,{ }^{* * *} \mathrm{p}<0.01$. Standard errors clustered by parish in brackets. 
Table A19: Interactions on Key Outcomes - Quality of Implementation (Table 1)

\begin{tabular}{|c|c|c|c|c|c|}
\hline & $\frac{\text { NGO visit }}{(1)}$ & $\frac{\text { Received leaflet }}{(2)}$ & $\frac{\text { Meetings Attended }}{(3)}$ & $\frac{\text { Received call }}{(4)}$ & $\frac{\text { Posters }}{(5)}$ \\
\hline Treatment village & $\begin{array}{c}0.374^{* * *} \\
{[0.021]}\end{array}$ & $\begin{array}{c}0.349^{* * *} \\
{[0.019]}\end{array}$ & $\begin{array}{c}0.311^{* * *} \\
{[0.031]}\end{array}$ & $\begin{array}{c}0.031^{* * *} \\
{[0.008]}\end{array}$ & $\begin{array}{c}0.183^{* * *} \\
{[0.016]}\end{array}$ \\
\hline Spillover & $\begin{array}{c}-0.003 \\
{[0.018]}\end{array}$ & $\begin{array}{l}-0.017^{*} \\
{[0.009]}\end{array}$ & $\begin{array}{c}-0.006 \\
{[0.023]}\end{array}$ & $\begin{array}{c}-0.003 \\
{[0.007]}\end{array}$ & $\begin{array}{c}-0.009 \\
{[0.010]}\end{array}$ \\
\hline Treatment*Saturation & $\begin{array}{c}-0.084^{* *} \\
{[0.040]}\end{array}$ & $\begin{array}{c}-0.025 \\
{[0.037]}\end{array}$ & $\begin{array}{c}-0.044 \\
{[0.055]}\end{array}$ & $\begin{array}{c}-0.004 \\
{[0.015]}\end{array}$ & $\begin{array}{c}0.014 \\
{[0.032]}\end{array}$ \\
\hline Spillover*Saturation & $\begin{array}{c}0.064 \\
{[0.045]}\end{array}$ & $\begin{array}{c}0.080^{* * *} \\
{[0.025]}\end{array}$ & $\begin{array}{c}0.021 \\
{[0.058]}\end{array}$ & $\begin{array}{c}-0.002 \\
{[0.019]}\end{array}$ & $\begin{array}{c}0.043 \\
{[0.028]}\end{array}$ \\
\hline Outside Sampling Frame & $\begin{array}{l}-0.006 \\
{[0.022]}\end{array}$ & $\begin{array}{c}-0.003 \\
{[0.013]}\end{array}$ & $\begin{array}{c}-0.012 \\
{[0.024]}\end{array}$ & $\begin{array}{c}0.001 \\
{[0.009]}\end{array}$ & $\begin{array}{l}-0.006 \\
{[0.012]}\end{array}$ \\
\hline ACFIM Presence & $\begin{array}{c}0.023 \\
{[0.038]}\end{array}$ & $\begin{array}{c}-0.013 \\
{[0.021]}\end{array}$ & $\begin{array}{c}-0.022 \\
{[0.048]}\end{array}$ & $\begin{array}{c}0.016 \\
{[0.019]}\end{array}$ & $\begin{array}{c}0.035 \\
{[0.024]}\end{array}$ \\
\hline ACFIM Village ${ }^{*}$ ACFIM Presence & $\begin{array}{c}0.025 \\
{[0.043]}\end{array}$ & $\begin{array}{c}0.015 \\
{[0.027]}\end{array}$ & $\begin{array}{c}0.019 \\
{[0.050]}\end{array}$ & $\begin{array}{c}-0.012 \\
{[0.019]}\end{array}$ & $\begin{array}{c}-0.026 \\
{[0.028]}\end{array}$ \\
\hline$R^{2}$ & 0.14 & 0.20 & 0.06 & 0.04 & 0.09 \\
\hline Control Mean & 0.198 & 0.052 & 0.113 & 0.040 & 0.062 \\
\hline Controls & Yes & Yes & Yes & Yes & Yes \\
\hline Observations & 27756 & 28007 & 27693 & 28454 & 28081 \\
\hline
\end{tabular}

Note: This table reports estimates from equation (3). All regressions include a dummy for out-of-sample villages, the parishlevel ACFIM presence, and their interaction. Dependent variables in this table are indicators of program implementation: whether the NGO visited (col. 1), distributed leaflets (col. 2), held meetings (col. 3), conducted robocalls (col. 4), or posted signs in the village (col. 5), as reported by respondents in the voter survey.

${ }^{*} \mathrm{p}<0.1,{ }^{* *} \mathrm{p}<0.05,{ }^{* * *} \mathrm{p}<0.01$. Standard errors clustered by parish in brackets. 
Table A20: Interactions on Electoral Outcomes (Table 2)

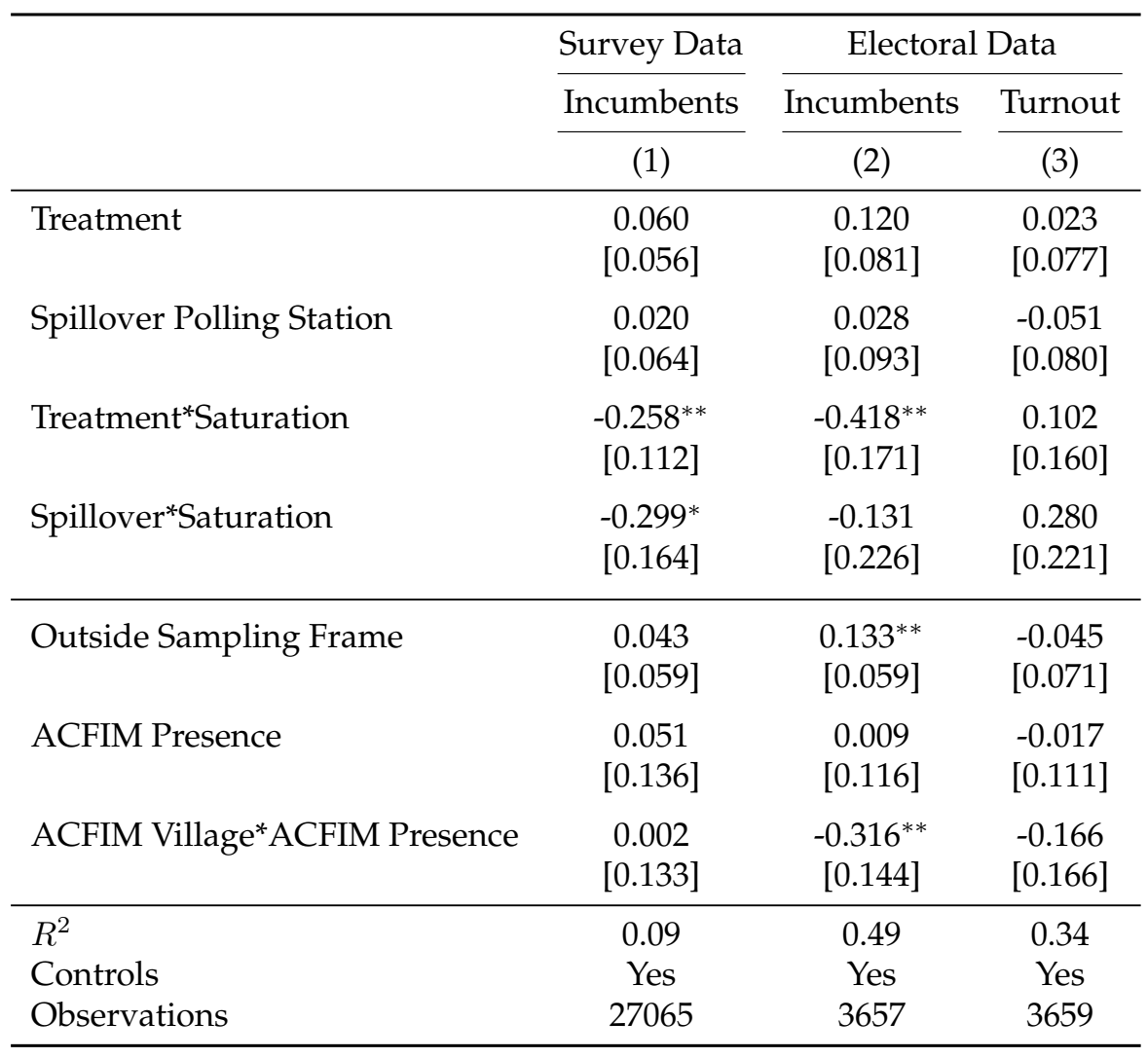

Note: This table reports estimates from equation (3). All regressions include a dummy for out-of-sample villages, the parishlevel ACFIM presence, and their interaction. Dependent variables are defined as in Table 2. All outcomes are standardized indices with mean zero in the control group.

${ }^{*} \mathrm{p}<0.1,{ }^{* *} \mathrm{p}<0.05,{ }^{* * *} \mathrm{p}<0.01$. Standard errors clustered by parish in brackets. 
Table A21: Interactions on Key Outcomes - Voter Reciprocity and Social Punishment (Table 3)

\begin{tabular}{|c|c|c|c|c|c|}
\hline & $\frac{\text { Supply of Votes }}{(1)}$ & $\frac{\text { Neg Consequences }}{(2)}$ & $\frac{\text { Services not delivered }}{(3)}$ & $\frac{\text { Social punishment }}{(4)}$ & $\frac{\text { Ostracizing }}{(5)}$ \\
\hline Treatment village & $\begin{array}{c}-0.044 \\
{[0.046]}\end{array}$ & $\begin{array}{c}-0.007 \\
{[0.013]}\end{array}$ & $\begin{array}{c}-0.021 \\
{[0.023]}\end{array}$ & $\begin{array}{l}0.039^{* *} \\
{[0.019]}\end{array}$ & $\begin{array}{l}0.052^{* *} \\
{[0.022]}\end{array}$ \\
\hline Spillover & $\begin{array}{c}-0.011 \\
{[0.046]}\end{array}$ & $\begin{array}{c}0.008 \\
{[0.013]}\end{array}$ & $\begin{array}{c}-0.041 \\
{[0.027]}\end{array}$ & $\begin{array}{c}0.008 \\
{[0.021]}\end{array}$ & $\begin{array}{c}-0.001 \\
{[0.024]}\end{array}$ \\
\hline Treatment*Saturation & $\begin{array}{c}-0.036 \\
{[0.082]}\end{array}$ & $\begin{array}{l}0.042^{*} \\
{[0.022]}\end{array}$ & $\begin{array}{l}0.091^{* *} \\
{[0.043]}\end{array}$ & $\begin{array}{c}-0.035 \\
{[0.033]}\end{array}$ & $\begin{array}{c}-0.063 \\
{[0.039]}\end{array}$ \\
\hline Spillover*Saturation & $\begin{array}{c}-0.044 \\
{[0.114]}\end{array}$ & $\begin{array}{c}0.008 \\
{[0.033]}\end{array}$ & $\begin{array}{c}0.078 \\
{[0.068]}\end{array}$ & $\begin{array}{c}0.024 \\
{[0.050]}\end{array}$ & $\begin{array}{l}-0.016 \\
{[0.059]}\end{array}$ \\
\hline Outside Sampling Frame & $\begin{array}{c}0.032 \\
{[0.055]}\end{array}$ & $\begin{array}{c}-0.012 \\
{[0.014]}\end{array}$ & $\begin{array}{c}0.024 \\
{[0.029]}\end{array}$ & $\begin{array}{c}-0.009 \\
{[0.024]}\end{array}$ & $\begin{array}{c}-0.007 \\
{[0.027]}\end{array}$ \\
\hline ACFIM Presence & $\begin{array}{c}-0.015 \\
{[0.109]}\end{array}$ & $\begin{array}{c}-0.037 \\
{[0.030]}\end{array}$ & $\begin{array}{c}-0.141^{* *} \\
{[0.062]}\end{array}$ & $\begin{array}{c}0.026 \\
{[0.045]}\end{array}$ & $\begin{array}{c}0.050 \\
{[0.053]}\end{array}$ \\
\hline ACFIM Village ${ }^{*}$ ACFIM Presence & $\begin{array}{c}0.099 \\
{[0.113]}\end{array}$ & $\begin{array}{c}0.011 \\
{[0.031]}\end{array}$ & $\begin{array}{c}0.076 \\
{[0.064]}\end{array}$ & $\begin{array}{c}-0.003 \\
{[0.048]}\end{array}$ & $\begin{array}{l}-0.016 \\
{[0.057]}\end{array}$ \\
\hline $\begin{array}{l}R^{2} \\
\text { Control Mean } \\
\text { Controls } \\
\text { Observations }\end{array}$ & $\begin{array}{c}0.03 \\
0.046 \\
\text { Yes } \\
28454\end{array}$ & $\begin{array}{c}0.04 \\
0.888 \\
\text { Yes } \\
28454\end{array}$ & $\begin{array}{c}0.03 \\
0.482 \\
\text { Yes } \\
28454\end{array}$ & $\begin{array}{c}0.04 \\
0.745 \\
\text { Yes } \\
28454\end{array}$ & $\begin{array}{c}0.07 \\
0.567 \\
\text { Yes } \\
27680\end{array}$ \\
\hline
\end{tabular}

Note: This table reports estimates from equation (3). All regressions include a dummy for out-of-sample villages, the parish-level ACFIM presence, and their interaction. Dependent variables in this table include: an index of the perceived fraction of village residents who would sell their vote at given price points (ranging from 1,000 to 50,000 Ugandan Shillings) and of the perceived acceptability of selling one's vote in the vignette experiment (col. 1, see text for details); an indicator for respondents saying vote buying has negative consequences for the village (col. 2); an indicator for respondents saying vote buying will result in services not being delivered to the community (col. 3); an indicator for beliefs that vote selling would lead to social sanctions (col. 4), and beliefs that fellow villages would ostracize vote-sellers (col. 5).

${ }^{*} \mathrm{p}<0.1,{ }^{* *} \mathrm{p}<0.05,{ }^{* * *} \mathrm{p}<0.01$. Standard errors clustered by parish in brackets. 
Table A22: Interactions on Key Outcomes - Vote-Buying Index (Table 4)

\begin{tabular}{|c|c|c|c|}
\hline & $\frac{\text { All Candidates }}{(1)}$ & $\frac{\text { Incumbents }}{(2)}$ & $\frac{\text { All Challengers }}{(3)}$ \\
\hline Treatment village & $\begin{array}{c}0.050 \\
{[0.047]}\end{array}$ & $\begin{array}{c}0.008 \\
{[0.048]}\end{array}$ & $\begin{array}{c}0.061 \\
{[0.047]}\end{array}$ \\
\hline Spillover & $\begin{array}{c}-0.025 \\
{[0.048]}\end{array}$ & $\begin{array}{c}-0.054 \\
{[0.054]}\end{array}$ & $\begin{array}{c}0.064 \\
{[0.059]}\end{array}$ \\
\hline Treatment*Saturation & $\begin{array}{c}-0.022 \\
{[0.089]}\end{array}$ & $\begin{array}{c}-0.003 \\
{[0.091]}\end{array}$ & $\begin{array}{c}0.002 \\
{[0.091]}\end{array}$ \\
\hline Spillover*Saturation & $\begin{array}{c}0.145 \\
{[0.123]}\end{array}$ & $\begin{array}{c}0.145 \\
{[0.137]}\end{array}$ & $\begin{array}{c}-0.053 \\
{[0.143]}\end{array}$ \\
\hline Outside Sampling Frame & $\begin{array}{c}0.000 \\
{[0.048]}\end{array}$ & $\begin{array}{c}0.031 \\
{[0.054]}\end{array}$ & $\begin{array}{c}-0.048 \\
{[0.055]}\end{array}$ \\
\hline ACFIM Presence & $\begin{array}{c}-0.068 \\
{[0.100]}\end{array}$ & $\begin{array}{c}-0.163 \\
{[0.111]}\end{array}$ & $\begin{array}{c}0.137 \\
{[0.107]}\end{array}$ \\
\hline ACFIM Village ${ }^{*}$ ACFIM Presence & $\begin{array}{c}0.041 \\
{[0.102]}\end{array}$ & $\begin{array}{c}0.094 \\
{[0.113]}\end{array}$ & $\begin{array}{c}-0.081 \\
{[0.111]}\end{array}$ \\
\hline $\begin{array}{l}R^{2} \\
\text { Controls } \\
\text { Observations }\end{array}$ & $\begin{array}{c}0.06 \\
\text { Yes } \\
28454\end{array}$ & $\begin{array}{c}0.06 \\
\text { Yes } \\
28454\end{array}$ & $\begin{array}{c}0.04 \\
\text { Yes } \\
28454\end{array}$ \\
\hline
\end{tabular}

Note: This table reports estimates from equation (3). All regressions include a dummy for out-of-sample villages, the parishlevel ACFIM presence, and their interaction. The dependent variable is a standardized index of the following variables: any cash received, natural log of the amount of cash received, any gift received, and log of the value of any gift received, measured for any candidate running in the presidential and parliamentary races (col. 1), or separately for incumbent candidates (col. 2) and challenger candidates (col. 3). All outcomes are standardized indices with mean zero in the control group.

${ }^{*} \mathrm{p}<0.1,{ }^{* *} \mathrm{p}<0.05,{ }^{* * *} \mathrm{p}<0.01$. Standard errors clustered by parish in brackets. 


\section{Table A23: Interactions on Key Outcomes - Vote Buying and Reciprocity (Table 5)}

\begin{tabular}{|c|c|c|}
\hline & Gifts from Competing Candidates & Did Not Reciprocate \\
\hline & (1) & (2) \\
\hline Treatment village & $\begin{array}{c}-0.019 \\
{[0.046]}\end{array}$ & $\begin{array}{c}0.046 \\
{[0.043]}\end{array}$ \\
\hline Spillover & $\begin{array}{c}-0.004 \\
{[0.051]}\end{array}$ & $\begin{array}{c}-0.001 \\
{[0.046]}\end{array}$ \\
\hline Treatment*Saturation & $\begin{array}{c}0.120 \\
{[0.095]}\end{array}$ & $\begin{array}{c}-0.012 \\
{[0.083]}\end{array}$ \\
\hline Spillover*Saturation & $\begin{array}{c}0.035 \\
{[0.124]}\end{array}$ & $\begin{array}{c}0.094 \\
{[0.115]}\end{array}$ \\
\hline Outside Sampling Frame & $\begin{array}{c}-0.006 \\
{[0.048]}\end{array}$ & $\begin{array}{c}0.048 \\
{[0.045]}\end{array}$ \\
\hline ACFIM Presence & $\begin{array}{c}0.011 \\
{[0.106]}\end{array}$ & $\begin{array}{c}-0.063 \\
{[0.101]}\end{array}$ \\
\hline ACFIM Village*ACFIM Presence & $\begin{array}{c}-0.002 \\
{[0.101]}\end{array}$ & $\begin{array}{c}0.133 \\
{[0.095]}\end{array}$ \\
\hline$R^{2}$ & 0.04 & 0.06 \\
\hline Controls & Yes & Yes \\
\hline Observations & 28454 & 28454 \\
\hline
\end{tabular}

Note: This table reports estimates from equation (3). All regressions include a dummy for out-of-sample villages, the parish-level ACFIM presence, and their interaction. The dependent variable in columns 1-2 is an indicator for respondents reporting they received cash from at least two competing candidates in the same electoral race (presidential or parliamentary). The dependent variable in columns 3-4 is an indicator for respondents reporting they accepted cash from a candidate but voted for a different candidate in a given race. All outcomes are standardized indices with mean zero in the control group.

${ }^{*} \mathrm{p}<0.1,{ }^{* *} \mathrm{p}<0.05,{ }^{* * *} \mathrm{p}<0.01$. Standard errors clustered by parish in brackets. 
Table A24: Interactions on Key Outcomes - Campaigning Index (Table 6)

\begin{tabular}{|c|c|c|c|}
\hline & $\frac{\text { All Candidates }}{(1)}$ & $\frac{\text { Incumbents }}{(2)}$ & $\begin{array}{c}\text { All Challengers } \\
(3)\end{array}$ \\
\hline Treatment village & $\begin{array}{c}-0.112 \\
{[0.071]}\end{array}$ & $\begin{array}{c}-0.060 \\
{[0.068]}\end{array}$ & $\begin{array}{l}-0.134^{*} \\
{[0.071]}\end{array}$ \\
\hline Spillover & $\begin{array}{c}-0.071 \\
{[0.076]}\end{array}$ & $\begin{array}{c}0.005 \\
{[0.075]}\end{array}$ & $\begin{array}{c}-0.119 \\
{[0.077]}\end{array}$ \\
\hline Treatment*Saturation & $\begin{array}{c}0.341^{* *} \\
{[0.147]}\end{array}$ & $\begin{array}{c}0.218 \\
{[0.139]}\end{array}$ & $\begin{array}{l}0.379^{* *} \\
{[0.147]}\end{array}$ \\
\hline Spillover*Saturation & $\begin{array}{c}0.140 \\
{[0.180]}\end{array}$ & $\begin{array}{c}-0.071 \\
{[0.177]}\end{array}$ & $\begin{array}{c}0.283 \\
{[0.184]}\end{array}$ \\
\hline Outside Sampling Frame & $\begin{array}{c}-0.012 \\
{[0.072]}\end{array}$ & $\begin{array}{c}0.024 \\
{[0.073]}\end{array}$ & $\begin{array}{c}-0.038 \\
{[0.070]}\end{array}$ \\
\hline ACFIM Presence & $\begin{array}{c}-0.131 \\
{[0.148]}\end{array}$ & $\begin{array}{c}-0.140 \\
{[0.145]}\end{array}$ & $\begin{array}{c}-0.101 \\
{[0.152]}\end{array}$ \\
\hline ACFIM Village*ACFIM Presence & $\begin{array}{c}-0.065 \\
{[0.148]}\end{array}$ & $\begin{array}{c}-0.004 \\
{[0.146]}\end{array}$ & $\begin{array}{c}-0.102 \\
{[0.148]}\end{array}$ \\
\hline $\begin{array}{l}R^{2} \\
\text { Controls } \\
\text { Observations }\end{array}$ & $\begin{array}{c}0.12 \\
\text { Yes } \\
28454\end{array}$ & $\begin{array}{c}0.13 \\
\text { Yes } \\
28454\end{array}$ & $\begin{array}{c}0.11 \\
\text { Yes } \\
28454\end{array}$ \\
\hline
\end{tabular}

Note: This table reports estimates from equation (3). All regressions include a dummy for out-of-sample villages, the parish-level ACFIM presence, and their interaction. The dependent variable is the standardized sum of indicators of campaigning activities: visit to the village, posters, leaflets, advertising over loudspeakers, and merchandise, measured for any candidate running in the presidential and parliamentary races (col. 1), or separately for incumbent candidates (col. 2) and challenger candidates (col. 3). All outcomes are standardized indices with mean zero in the control group.

${ }^{*} \mathrm{p}<0.1,{ }^{* *} \mathrm{p}<0.05,{ }^{* * *} \mathrm{p}<0.01$. Standard errors clustered by parish in brackets. 
Table A25: Test of Social Desirability Bias

\begin{tabular}{lccccc}
\hline & \multicolumn{2}{c}{ Vote-Buying 2011 } & & \multicolumn{2}{c}{ NRM Vote 2011 } \\
\cline { 2 - 3 } \cline { 6 - 6 } & $(1)$ & $(2)$ & & $(3)$ & $(4)$ \\
\hline Treatment village & -0.002 & & -0.004 & \\
& {$[0.010]$} & & {$[0.008]$} & \\
Spillover & -0.003 & & -0.008 & \\
& {$[0.012]$} & & {$[0.009]$} & \\
Treatment Saturation & & -0.007 & & -0.019 \\
& & {$[0.018]$} & & {$[0.013]$} \\
\hline Outside Sampling Frame & -0.011 & -0.011 & & -0.002 & -0.005 \\
& {$[0.011]$} & {$[0.008]$} & & {$[0.009]$} & {$[0.006]$} \\
ACFIM Presence & -0.001 & 0.003 & & 0.018 & $0.028^{*}$ \\
& {$[0.017]$} & {$[0.020]$} & {$[0.013]$} & {$[0.015]$} \\
\hline$R^{2}$ & 0.07 & 0.07 & 0.09 & 0.09 \\
Control Mean & 0.22 & 0.22 & & 0.84 & 0.84 \\
Controls & Yes & Yes & Yes & Yes \\
Observations & 28454 & 28454 & 21785 & 21785 \\
\hline
\end{tabular}

Note: ${ }^{*} \mathrm{p}<0.1,{ }^{* *} \mathrm{p}<0.05,{ }^{* * *} \mathrm{p}<0.01$. Standard errors clustered by parish in brackets. All regressions control for an ACFIM dummy (in-sample villages) and the parish-level ACFIM presence. The dependent variables in this table are: whether the respondent reported selling their vote in 2011 (cols. 1-2), and whether they reported voting for the NRM in 2011 (cols. 3-4). 